\title{
AJUSTE MACROECONÔMICO E PREÇO RELATIVO AGRICULTURA-INDÚSTRIA NO BRASIL: 1982/88
}

\section{WILSON DA CRUZ VIEIRA}

\author{
Engenheiro Agrônomo
}

Orientador: Prof. Dr. GUILHERME LEITE DA SILVA DIAS

Tese apresentada à Escola Superior de Agricultura Luiz de Queiroz, da Universidade de São Paulo, para obtenção do título de Doutor em Agronomia, Área de Concentração: Economia Agrária.

\section{PIRACICABA}

Estado de São Paulo - Brasil

Setembro - 1995 


\begin{tabular}{|c|}
\hline $\begin{array}{c}\text { USP - Campus do Piracicabe } \\
\text { DIVISÃO DE BIBLIOTECA } \\
\text { E DOCUMENTAÇÃO }\end{array}$ \\
\hline $\begin{array}{l}\text { Data: os/12195 } \\
\text { Proc: } 2,0 \text { antan } \\
\text { Rs: } 20,00 \\
\text { Req: - }\end{array}$ \\
\hline $\begin{array}{l}\text { N.et } 338.1 \text { vol, } \\
\text { cham. V658a }\end{array}$ \\
\hline
\end{tabular}

CATALOGAÇÃO DA PUBLICAÇÃO DIVISÃO DE BIBLIOTECA E DOCUMENTAÇÃO CAMPUS LUIZ DE QUEIROZ / USP

Vieira, Wilson da Cruz

Ajuste macroeconômico e preço relativo agricultura-indústria no Brasil: 1982/88. Piracicaba, 1995.

$134 \mathrm{p}$.

Tese - ESALQ

Bibliografia.

1. Indústria agrícola - Macroeconomia 2. Política cambial 3. Política monetária 4. Preço agrícola I. Escola Superior de Agricultura Luiz de Queiroz, Piracicaba.

CDD 338.1 


\section{AJUSTE MACROECONÔMICO E PREÇO RELATIVO AGRICULTURA-INDÚSTRIA NO BRASIL: 1982/88}

\section{WILSON DA CRUZ VIEIRA}

Aprovada em: 22.09 .1995

Comissão julgadora:

Prof. Dr. Guilherme Leite da Silva Dias

FEA/USP

Prof. Dr. Geraldo S. A. de Camargo Barros

ESALQ/USP

Prof. Dr. Carlos José Caetano Bacha

ESALQ/USP

Prof. Dr. José Maria Alves da Silva

DER/UFV

Dr. Francisco Alberto Pino

IEA/SAASP

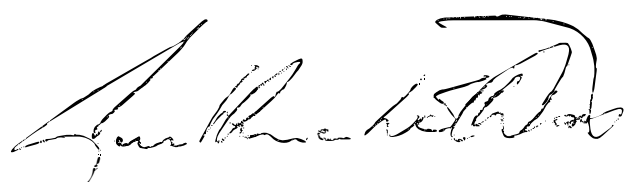

Prof. Dr. GUILHERME LEITE DA SILVA DIAS

Orientador 
Aos meus pais, Maria de Lourdes e Francisco Lopes Vieira, exemplos de vida.

Aos meus irmãos, Iolanda, Orlando, Nilton e Ana Rosa, pelo apoio e estímulos. 


\section{AGRADECIMENTOS}

Ao Departamento de Economia e Sociologia Rural (DESR) da Escola Superior de Agricultura Luiz de Queiroz (ESALQ), Universidade de São Paulo (USP), pela oportunidade de cursar o doutorado.

Ao Departamento de Economia Rural da Universidade Federal de Viçosa (DER/UFV), pela liberação de minhas atividades para conclusão do curso de doutorado e pelas facilidades materiais oferecidas.

Ao Prof. Guilherme Leite da Silva Dias, pelo apoio e orientação deste estudo.

Aos professores Geraldo S. A. de Camargo Barros, Carlos José Caetano Bacha, José Maria Alves da Silva e ao pesquisador Francisco Alberto Pino, pelas inúmeras sugestões.

Ao CNPq e à CAPES (programa PICD), pelo suporte financeiro concedido.

Aos colegas do curso de pós-graduação e aos professores e funcionários do DESR, pela agradável convivência durante o curso.

À Mirian Bacchi e ao Marcos Hasegawa, pelas proveitosas discussões na área de econometria.

Ao Nelson Coeli e à Adelaide Lopes, pelas sugestões lingüísticas.

À Pompéia, pelo carinho e paciência durante a fase de execução desta pesquisa. 


\section{SUMÁRIO}

Página

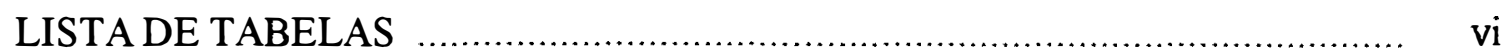

LISTA DE TABELAS DO APÊNDICE 2 ................................................ vii

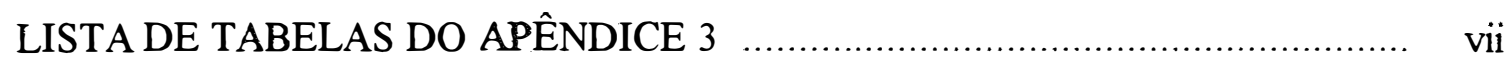

LISTA DE FIGURAS …..................................................................... viii

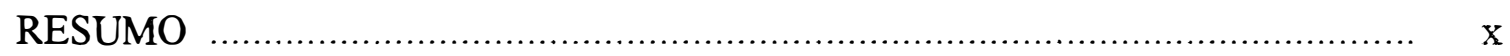

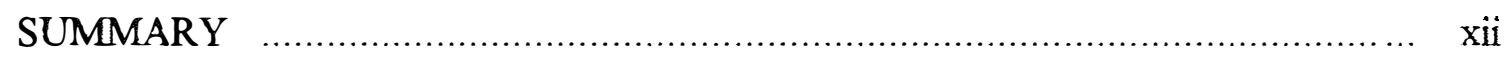

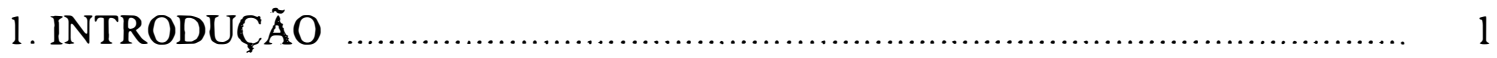

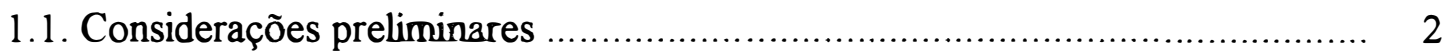

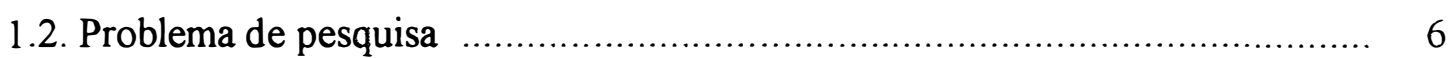

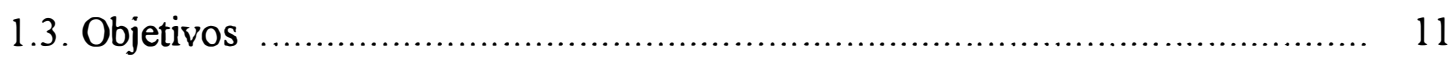

1.4. Organização do estudo ............................................................ 12

2. CRISE DO SETOR EXTERNO E AJUSTE MACROECONÔMICO _.............. 13

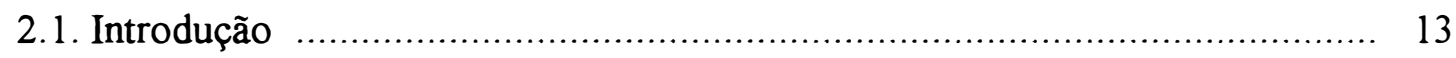

2.2. Estrutura de intermediação financeira nacional ................................... 17

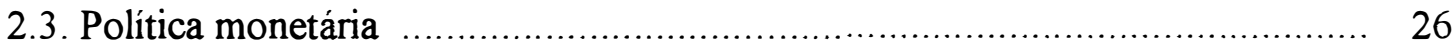

2.3.1. Recolhimento compulsório ..................................................... 27

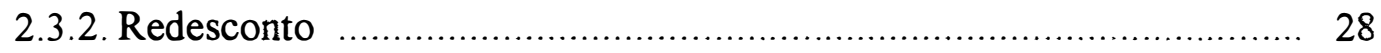

2.3.3. Operações de mercado aberto ................................................. 29

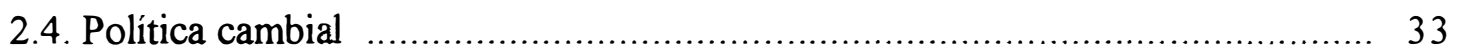

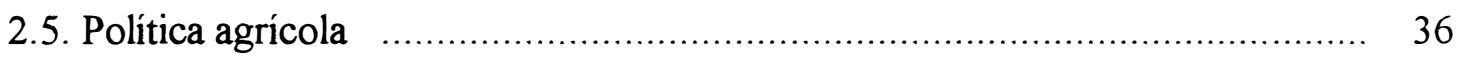

3. INTERDEPENDÊNCIA ENTRE AGRICULTURA E MERCADO FINANCEIRO:

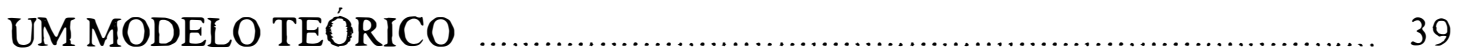

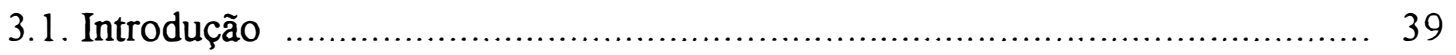

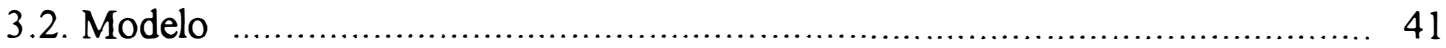

3.2.1. Setor financeiro ............................................................. 41

3.2.2. Setor de produção de bens …............................................. 45 
3.3. Experimentos de estática comparativa ............................................. 56

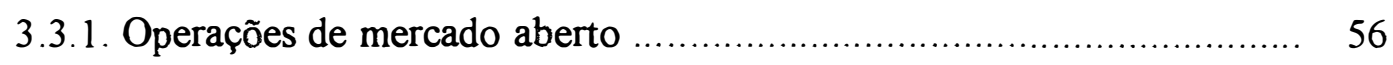

3.3.2. Desvalorizações cambiais .......................................................... 58

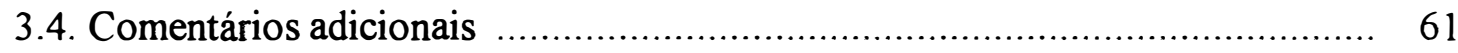

4. ANÁLISE EMPÍRICA: METODOLOGIA E RESULTADOS ......................... 64

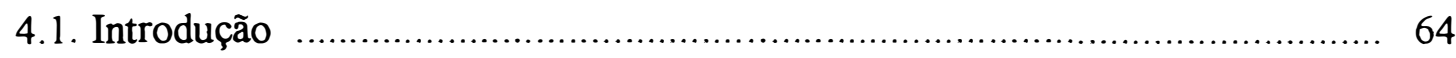

4.2. Raiz unitária, co-integração e modelo de correção de erro (MCE) ............... 65

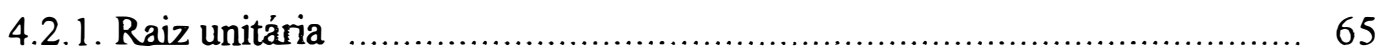

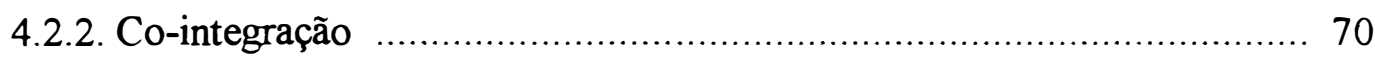

4.2.3. Modelo de correção de erro (MCE) …...................................... 72

4.3. Modelo de auto-regressão vetorial (VAR) …....................................... 73

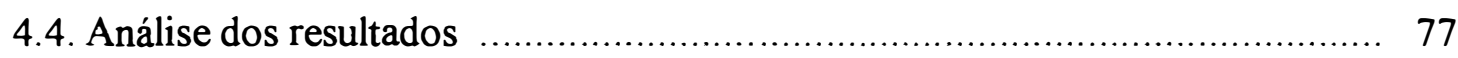

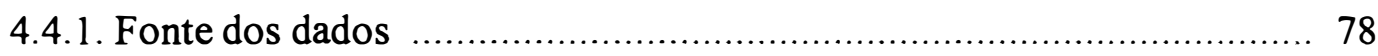

4.4.2. Modelo VAR com as variáveis em nível …................................ 80

4.4.3. Modelo de correção de erro (MCE) ............................................. 89

4.4.4. Modelo VAR em nível e MCE - taxa de juros exógena ..................... 99

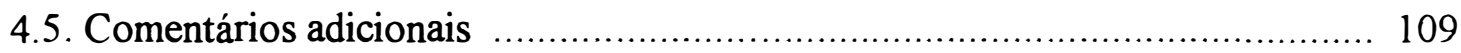

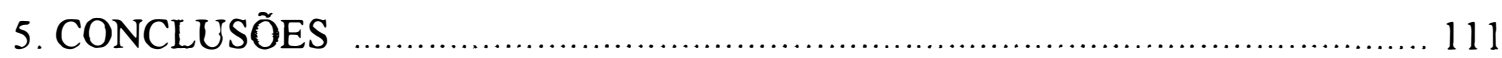

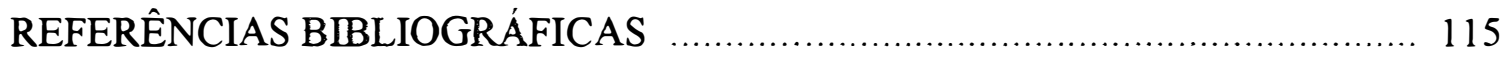

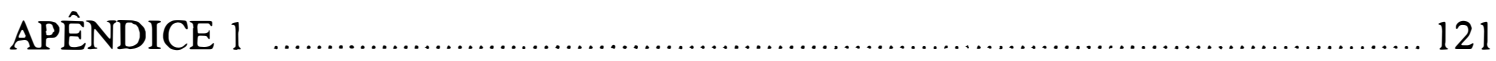

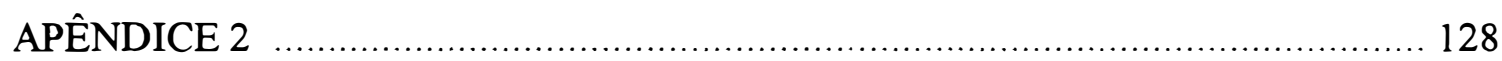

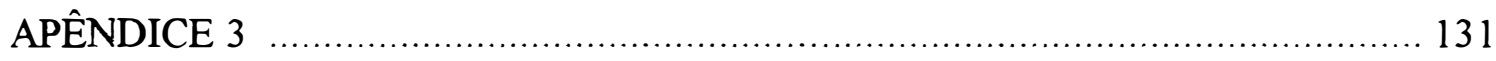




\section{LISTA DE TABELAS}

Tabela $n^{\circ}$

Página

01 Principais indicadores da economia brasileira. 1980/89 ..................... 14

02 Balancete consolidado das autoridades monetárias …......................... 22

03 Balancete consolidado do setor privado não-financeiro ........................ 23

04 Balancete analítico do Banco Central do Brasil (anos: 1984, 1986, 1988)percentagens .................................................................. 25

05 Colocação de títulos públicos e base monetária, 1982/88 (NCZ\$ mil) .... 31

06 Indicadores da taxa de câmbio real no Brasil, 1980/88 (base:1985=100).. 35

07 Efeitos de operações de mercado aberto com títulos domésticos e de desvalorizações cambiais sobre o preço relativo agricultura-indústria ...... 60

08 Critérios de informação para escolha do número de defasagens do VAR ..

09 Matrizes de interações contemporâneas $\left(\mathrm{A}_{0}\right)$ dos modelos VAR com 3 e 6 defasagens (variáveis em nível)

10 Elasticidades de impulso sobre o preço relativo agricultura-indústria dos modelos VAR com 3 e 6 defasagens (variáveis em nível)

11 Decomposição da variância de previsão do preço relativo agriculturaindústria, em percentagem (modelo VAR em nível com 3 e 6 defasagens). 88

12 Teste DICKEY-FULLER para não-estacionariedade .......................... 90

13 Teste PHILLIPS-PERRON para não-estacionariedade ........................ 91

14 Teste JOHANSEN-JUSELIUS para co-integração (VAR - 3 defasagens). 91

15 Teste JOHANSEN-JUSELIUS para co-integração (VAR - 6 defasagens). 92

16 Matrizes de interações contemporâneas $\left(\mathrm{A}_{0}\right)$ dos modelos de correção de erro com 3 e 6 defasagens (variáveis nas primeiras diferenças) ................ 94

17 Elasticidades de impulso sobre o preço relativo agricultura-indústria dos modelos de correção de erro com 3 e 6 defasagens(variáveis nas primeiras diferenças)

18 Decomposição da variância de previsão do preço relativo agriculturaindústria, em percentagem (MCE - 3 e 6 defasagens, las. diferenças) ... 
19 Matriz de interações contemporâneas $\left(\mathrm{A}_{0}\right)$ do modelo VAR em nivel com 3 defasagens - taxa de juros exógena 101

20 Elasticidades de impulso sobre o preço relativo agricultura-indústria do modelo VAR em nível com 3 defasagens - taxa de juros exógena 102

21 Decomposição da variância de previsão do preço relativo agriculturaindústria do modelo VAR em nível com 3 defasagens, em percentagem taxa de juros exógena

22 Matriz de interações contemporâneas $\left(\mathrm{A}_{0}\right)$ do MCE com 6 defasagens (variáveis nas primeiras diferenças) - taxa de juros exógena

23 Elasticidades de impulso sobre o preço relativo agricultura-indústria do MCE com 6 defasagens(variáveis nas primeiras diferenças)-taxa de juros exógena

24 Decomposição da variância do erro de previsão do preço relativo agricultura-indústria do MCE com 6 defasagens (variáveis nas primeiras diferenças, em percentagem - taxa de juros exógena

\section{LISTA DE TABELAS DO APÊNDICE 2}

Tabela $n^{\circ}$ Página

A2 Valores críticos das estatísticas $\tau, \tau_{\mu}$ e $\tau_{\tau}$ para raiz unitária, a 0,01 e 0,05 de probabilidade, para 50 e 100 observações

\section{LISTA DE TABELAS DO APÊNDICE 3}

Tabela $n^{\circ}$

Página

A3 Séries de dados utilizados na investigação empírica, período outubro/82 a dezembro/88 


\section{LISTA DE FIGURAS}

Figura $n^{\circ}$

Página

01 Índices da taxa de câmbio real efetiva e do preço relativo agriculturaindústria, período outubro/82 a dezembro/88

02 Representação esquemática do sistema financeiro brasileiro

03 Evolução da taxa nominal de juros, período outubro/82 a dezembro/88.

04 Evolução dos meios de pagamento (M1), período outubro/82 a dezembro/88

05 Elasticidades de impulso da taxa de câmbio real sobre o preço relativo agricultura-indústria(modelos VAR em nível com 3 e 6 defasagens) .....

06 Elasticidades de impulso da oferta monetária sobre o preço relativo agricultura-indústria (modelos VAR em nível com 3 e 6 defasagens) ....

07 Elasticidades de impulso da taxa nominal de juros sobre o preço relativo agricultura-indústria (modelos VAR em nível com 3 e 6 defasagens) ....

08 Elasticidades de impulso da taxa de câmbio real sobre o preço relativo agricultura-indústria dos modelos de correção de erro-3 e 6 defasagens

09 Elasticidades de impulso da oferta monetária sobre o preço relativo agricultura-indústria dos modelos de correção de erro-3 e 6 defasagens

10 Elasticidades de impulso da taxa nominal de juros sobre preço relativo agricultura-indústria dos modelos de correção de erro-3 e 6 defasagens

11 Elasticidades de impulso da taxa de câmbio real sobre o preço relativo agricultura-indústria do modelo VAR em nível com 3 defasagens-taxa de juros exógena

12 Elasticidades de impulso da oferta monetária sobre o preço relativo agricultura-indústria do modelo VAR em nível com 3 defasagens-taxa de juros exógena 
13 Elasticidades de impulso da taxa nominal de juros sobre o preço relativo agricultura-indústria do VAR em nivel com 3 defasagens taxa de juros exógena

14 Elasticidades de impulso da taxa de câmbio real sobre o preço relativo agricultura-indústria do MCE-6 defasagens - taxa de juros exógena ....

15 Elasticidades de impulso da oferta monetária sobre o preço relativo agricultura-indústria do MCE- 6 defasagens - taxa de juros exógena ...

16 Elasticidades de impulso da taxa nominal de juros sobre preço relativo agricultura-indústria do MCE-6 defasagens - taxa de juros exógena ... 


\section{AJUSTE MACROECONÔMICO E PREÇO RELATIVO AGRICULTURA-INDÚSTRIA NO BRASIL: 1982/88}

Autor: WILSON DA CRUZ VIEIRA

Orientador: PROF. DR. GUILHERME LEITE DA SILVA DIAS

\section{RESUMO}

Neste estudo investiga-se, teórica e empiricamente, os efeitos de políticas monetárias e cambiais sobre o preço relativo agricultura-indústria. No modelo teórico desenvolvido para esse propósito, considera-se uma pequena economia aberta com taxa de câmbio fixa que transaciona bens e ativos com o resto do mundo. Os preços agrícolas são formados em mercados de concorrência perfeita e os preços industriais, por meio de uma regra de markup. Nesta economia pode haver mecanismos de indexação na formação do preço industrial e/ou na taxa de câmbio.

Nos experimentos de estática comparativa com o modelo teórico mostrase que os efeitos dessas políticas sobre o termo doméstico de troca agricultura-indústria depende da forma de indexação considerada. Uma política monetária expansionista reduz a taxa de juros e melhora o termo doméstico de troca em favor da agricultura quando a taxa de câmbio não é indexada. Esta política, por outro lado, não afeta o preço relativo agricultura-indústria quando há indexação perfeita na economia.

Os efeitos de desvalorizações cambiais, sob a suposição de que a oferta de moeda é mantida fixa, são inequívocos nos casos em que há indexação perfeita da economia ou quando há indexação apenas na formação do preço industrial. Nesses dois casos, os preços industriais crescem proporcionalmente mais do que os preços agrícolas. Nos demais casos, os efeitos das políticas monetárias e cambiais foram ambíguos ou obtinham-se expressões complexas de pouca utilidade analítica. 
A investigação empírica foi desenvolvida com base no modelo teórico e considerou o período de outubro de 1982 a dezembro de 1988. Esse período foi marcado, em grande parte, por tentativas de ajuste da economia brasileira à crise da dívida externa. Utilizaram-se modelos de auto-regressão vetorial (VAR) e consideraramse as seguintes variáveis: oferta monetária (M1), taxa nominal de juros, taxa de câmbio real efetiva e índices de preços por atacado agrícola e industrial. Realizaram-se testes de raiz unitária e de co-integração nas séries de dados consideradas e testes para escolha do número de defasagens nos modelos empíricos. Com base nesses testes estimaram-se modelos VAR com as variáveis em nível e na forma de correção de erro com 3 e 6 defasagens.

Os resultados obtidos com os modelos empíricos dão suporte à hipótese de que as políticas monetárias e cambiais afetam o termo doméstico de troca agriculturaindústria, no curto prazo. Dentre os principais resultados, destaca-se o de que os choques não antecipados na taxa de câmbio real afetam proporcionalmente mais o preço relativo agricultura-indústria do que choques da mesma magnitude na oferta monetária ou na taxa nominal de juros. Esta regularidade estatística manteve-se mesmo admitindose duas formas alternativas de identificação da matriz de interações contemporâneas dos modelos empíricos. 


\section{MACROECONOMIC ADJUSTMENTS AND AGRICULTURAL- INDUSTRIAL RELATIVE PRICES IN BRAZIL: 1982/88}

Autor: WILSON DA CRUZ VIEIRA

Orientador: PROF. DR. GUILHERME LEITE DA SIL VA DIAS

\section{SUMMARY}

This study investigates both theoretical and empirical effects of changes in money supply and exchange rate on the agricultural-industrial price ratios. The theoretical model considers a small open economy under fixed exchange rate which is engaged in transactions with the rest of the world in both asset and good markets. The agricultural prices result from competitive markets and the industrial prices are formed by a markup rule. In this economy there is possibility of indexation on the industrial price formation and/or on the exchange rate.

Results from comparative static experiments using the theoretical model show that the effects of monetary and exchange rate policies on the agriculturalindustrial domestic terms of trade depend upon the indexation form being considered. An expansionist monetary policy reduces the interest rate and improves the domestic terms of trade in favor of agriculture when the exchange rate is not indexed. This policy, on the other side, does not affect the agricultural-industrial relative prices when there is perfect indexation in the economy.

Under the assumption that the money supply is not altered, the effects of depreciation of the exchange rate are unequivocals in the cases of perfect indexation of the economy or when there is indexation only in the formation of the industrial price. In these cases, the industrial prices grow proportionaly more than the agricultural prices. In 
the others cases of indexation, the effects of monetary and exchange rate policies were ambiguous or the expressions obtained were complexes for analysis.

The empirical investigation was developed as a practical application of the theoretical model. It was considered the period from october 1982 to december 1988, which was marked, in great part, for attempts of adjustment of the Brazilian economy to the crisis of the external debt. Vector autoregressive models were used and the following variables were considered: money supply (M1), nominal interest rate, real exchange rate and agricultural and industrial wholesale price indexes. Unit root and co-integration tests were done for the variables, as well as, lag length tests for the empirical models. Vector autoregressive models in level and in the error correction form with 3 and 6 lags were estimated.

The results of the empirical models support the hypothesis that the monetary and exchange rate policies affect the agricultural-industrial domestic terms of trade in the short run. The main result is: the shocks on the real exchange rate affect proportionately more the agricultural-industrial relative prices than shocks of the same strength on the money supply or on the nominal interest rate. This statistical regularity is kept if two alternative forms of identification for the contemporaneous interaction matrix for the empirical models are considered. 


\section{INTRODUÇÃO}

O presente estudo visa investigar os efeitos de políticas monetárias e cambiais sobre a agricultura brasileira na década de 80 . O interesse principal é analisar os impactos dessas políticas sobre o termo doméstico de troca, ou seja, a relação entre os preços nominais por atacado agrícolas e industriais. A análise limita-se ao período de outubro de 1982 a dezembro de 1988. Este período tem início logo após a decretação da moratória do México e antecede o ano de 1989, ano este em que houve um crescimento relativamente acelerado de preços na economia brasileira.

Nos anos oitenta a condução da política macroeconômica brasileira sofreu uma série de mudanças visando o ajustamento à crise da dívida externa. Assim, na primeira metade dessa década, a política monetária era restritiva e a taxa de câmbio real tendeu a se depreciar. Em 1986 a política monetária foi expansionista. Houve, na segunda metade dessa década, diversos planos de estabilização que adotaram medidas heterodoxas como congelamento de preços, salários e taxa de câmbio nominal. Nesse período, houve uma tendência à apreciação da moeda.

Ao longo da década de 80 o preço relativo agricultura-indústria sofreu mudanças acentuadas. Convém observar que, no final da década de 70 e início da década de 80 , os preços de commodities agrícolas estiveram deprimidos e que houve uma seca no ano agrícola 1985/86. Não obstante a importância desses fatores para explicar variações de preços relativos, argumenta-se e procura-se mostrar, neste estudo, que os distúrbios monetários e cambiais ocorridos nesse período foram responsáveis por parcela importante da forte variação do preço relativo agricultura-indústria. 


\subsection{Considerações preliminares}

No final da década de 70 e início da década de 80 , a economia brasileira experimentou uma crescente deterioração de sua situação externa. Fatores como o segundo choque do petróleo, o aumento das taxas de juros internacionais, a recessão mundial e a piora nos termos de intercâmbio levaram ao surgimento de déficits crescentes nas transações correntes. O balanço de pagamentos, em situação desfavorável, dificultou a continuação do pagamento do serviço da dívida externa. ${ }^{1}$

Essa deterioração da situação externa foi atenuada devido à utilização das reservas internacionais e à disponibilidade de crédito externo. Entretanto, houve um agravamento dessa crise com a interrupção dos fluxos voluntários de crédito externo logo após a decretação da moratória do México, em setembro de 1982, o que levou a economia brasileira praticamente a um estado de insolvência externa.

Por ocasião da interrupção dos fluxos voluntários de crédito externo, a dívida externa concentrava-se nas mãos do setor público. Esta estatização da dívida resultou da participação crescente deste setor nos empréstimos externos, para financiar os déficits em transações correntes, e da transferência para o Banco Central de grande parte da divida externa contratada originalmente pelo setor privado. ${ }^{2} \mathrm{O}$ governo brasileiro foi obrigado, então, a negociar com a comunidade financeira internacional (Fundo Monetário Internacional - FMI, bancos credores e Clube de Paris) o refinanciamento da dívida pública externa.

Sendo o principal devedor em moeda estrangeira, o governo teve que reduzir as transferências ao setor privado e os investimentos públicos, para transferir recursos ao exterior. Como há limites para essa transferência com recursos públicos,

\footnotetext{
Ver DALL'ACQUA (1992).

' Ver CRUZ (1984).
} 
recorreu-se também à poupança privada, por meio da colocação líquida de títulos públicos federais e/ou emissão de moeda. Esta expansão do endividamento interno do governo para cobrir encargos com a dívida pública externa caracteriza o que se convencionou chamar de substituição da dívida externa por dívida interna. ${ }^{3}$

Utilizaram-se duas estratégias distintas de ajuste macroeconômico com o propósito de superar a crise em que se encontrava a economia brasileira. ${ }^{4} \mathrm{~A}$ primeira, no período 1982/84, foi negociada com o FMI e teve caráter recessivo. Esta estratégia buscou reequilibrar as contas externas e reduzir a inflação. $\mathrm{Na}$ segunda, no período 1986/89, foram implantados vários programas não-recessivos de estabilização. Esta segunda estratégia também buscou reduzir a inflação, mas de forma a minimizar os efeitos sobre a distribuição de renda e o nível de produção.

É importante notar que, em geral, os custos do ajustamento do tipo desse a que foi submetida a economia brasileira, em função da crise da dívida externa, não são uniformemente distribuídos entre os diversos setores da economia. Os setores de bens comercializáveis e/ou com preços flexíveis arcam com parte substancial desses custos. A agricultura, por exemplo, sendo um setor de bens comercializáveis, cujos preços são tidos como flexíveis, é diretamente afetada pelas políticas macroeconômicas, sendo responsável por grande parte desses ajustamentos.

Uma desvalorização cambial, por exemplo, aumenta a competitividade dos setores exportadores da economia e desestimula as importações. Se o país é um típico exportador de bens agrícolas, este tipo de política beneficia diretamente o setor agrícola relativo aos demais setores de bens não-comercializáveis. No caso de uma política monetária restritiva que aumenta a taxa de juros, por exemplo, os custos de estocagem de bens agrícolas são elevados. Como consequiência disso, a oferta de curto prazo agrícola é aumentada, reduzindo os preços desses bens.

\footnotetext{
${ }^{3}$ CAVALCANTI (1988) faz uma análise detalhada dessa hipótese de substituição de dívida externa por dívida interna.

${ }^{4}$ Ver DALL'ACQUA (1992) para uma análise sucinta dessas estratégias macroeconômicas de ajuste e dos seus efeitos na definição da política agrícola.
} 
O ajuste da economia brasileira à crise da dívida externa nos anos oitenta seguramente afetou de forma diferenciada os diversos setores, ou seja, estes setores responderam de forma distinta às mudanças nas políticas monetárias e cambiais. Um aspecto importante dessa resposta diferenciada entre setores da economia às mudanças na política econômica é o comportamento dos preços relativos. Existe uma vasta literatura que mostra, por meio de análise estatística, que os preços de bens agrícolas, por exemplo, apresentam uma maior dispersão do que os preços de bens manufaturados. ${ }^{5}$

Há referências antigas sobre o comportamento diferenciado entre os preços de bens agrícolas e os de bens manufaturados. THOMPSON (1988) cita, por exemplo, que no final do século 19 , William J. Bryan, candidato à presidência dos Estados Unidos da América, atacou o padrão ouro, defendendo a livre cunhagem da prata para livrar os agricultores das condições deprimidas em que se encontravam. (Essa livre cunhagem da prata aumentaria a liquidez da economia). Ele argumentava que os agricultores americanos estavam sendo crucificados numa cruzada do ouro.

Episódios mais recentes envolvendo variações acentuadas dos preços dos bens agrícolas ocorreram nas três últimas décadas. Nos anos sessenta, os preços agrícolas americanos estiveram deprimidos; nos anos setenta, estes preços cresceram mais do que outros preços da economia americana; e, no final dos anos setenta e início dos anos oitenta, esses preços voltaram a experimentar uma fase depressiva. As politicas macroeconômicas utilizadas nesses diferentes periodos têm sido citadas para explicar esta forte variação dos preços agrícolas relativa a outros preços da economia.

SCHUH (1974) argumenta que a sobrevalorização do dólar nos anos sessenta é responsável pela depressão dos preços agrícolas americanos. A ligação entre a oferta de moeda e a agricultura seria indireta, via taxa de câmbio. Os preços agrícolas elevados na primeira metade dos anos setenta são também associados à política cambial

\footnotetext{
${ }^{5}$ Ver, por exemplo, CONTADOR \& SILVA JR. (1992), REZENDE (1992), LOYOLA (1991), SAYAD (1985) ou MOURA DA SILVA \& KADOTA (1982) para uma análise desse tipo para a economia brasileira.
} 
americana. Houve duas desvalorizações do dólar nesse período: uma em agosto de 1971 e a outra em fevereiro de 1973. No final dos anos setenta e início dos anos oitenta, as taxas internacionais de juros elevadas têm sido apontadas como um dos mais importantes fatores para explicar a forte queda observada nos preços das commodities agrícolas.

Em adição a esses canais básicos de ligação (taxas de câmbio e de juros) entre a política macroeconômica e a agricultura está a hipótese de que os preços agrícolas são mais flexíveis do que os preços de bens manufaturados. Esta hipótese é justificada pelo fato de as informações serem mais difundidas nos mercados agrícolas, pela exposição deste setor ao mercado externo e pela comercialização de commodities agrícolas em bolsas de mercadorias. No setor industrial, a existência de contratos de longo prazo e os custos de ajustamento às condições de mercado tornam mais lenta a resposta aos preços.

Essas hipóteses teóricas têm recebido um tratamento formal mais detalhado. STAMOULIS \& RAUSSER (1988), por exemplo, propuseram um modelo teórico que mostra que, sob certas condições, os preços de commodities agrícolas podem ultrapassar seus valores de equilíbrio de longo prazo (fenômeno do overshooting de preços agrícolas). Estes autores utilizaram como hipótese básica uma pequena economia aberta com taxa de câmbio flexivel, num mundo com perfeita mobilidade de capital e perfeita substitutibilidade entre ativos financeiros doméstico e externo.

FRANKEL (1986) propôs um modelo teórico que mostra que o fenômeno do overshooting de preços agricolas pode ocorrer numa economia fechada. A hipótese básica desse modelo é a de que os preços agrícolas são flexíveis e os preços industriais são rígidos, no curto prazo. Uma redução na oferta nominal de moeda faz com que a taxa real de juros aumente, deprimindo os preços reais das commodities agrícolas. Estes preços podem cair abaixo de seus níveis de equilíbrio de longo prazo, de forma a gerar uma expectativa de apreciação futura para compensar a taxa de juros maior 
Segundo FRANKEL (1986), esses efeitos da política monetária sobre os preços reais de commodities agrícolas (que desaparecem no longo prazo) podem-se dar via mudança da oferta de moeda ou via taxa de mudança da oferta monetária. No caso, por exemplo, de um aumento da taxa esperada de inflação devido a um acréscimo na taxa de expansão monetária, os investidores sairão de moeda e irão para commodities. A expectativa sobre a taxa de inflação futura, aumentando a demanda por commodities agrícolas, gera um efeito presente positivo sobre seus preços.

\subsection{Problema de pesquisa}

A relação entre a política macroeconômica e a agricultura tem chamado a atenção, como não poderia deixar de ser, de diversos economistas agrícolas. Dentre os trabalhos sobre a economia brasileira na mesma linha do presente estudo, ou seja, que utilizam na investigação empírica modelos de auto-regressão vetorial (VAR), destacamse os de BESSLER (1984), BRANDÃO (1985), BURNQUIST (1992), ${ }^{6}$ BARROS $(1992)^{7}$ e BRANDÃO \& ORDEN (1993). Estes trabalhos abrangem periodos distintos e, de modo geral, consideram um conjunto específico de variáveis.

BESSLER (1984) investigou empiricamente a relação entre a política monetária e o preço relativo da agricultura vis-à-vis a indústria, no período 1964/81. Este autor utilizou dados mensais de oferta monetária (M1), preços recebidos pelos produtores e preços industriais por atacado. Dentre as principais conclusões desse trabalho destacam-se: primeiro, existe uma causalidade forte de oferta monetária para preços agrícolas e foi observado um feedback de preços industriais para oferta monetária; segundo, a evidência encontrada de que os preços agrícolas se ajustam mais rapidamente do que os preços industriais a um choque na oferta monetária foi fraca.

\footnotetext{
${ }^{6}$ Ver BURNQUIST \& KYLE (1992) para uma versão mais resumida deste trabalho.

Ver BARROS (1990) para uma versão mais extensiva deste trabalho.
} 
BRANDÃO (1985) realizou uma análise semelhante à de BESSLER (1984). Esse autor utilizou dados mensais de oferta monetária (M1) e de índices de preços por atacado agrícola e industrial e considerou, na sua análise, o período de julho de 1969 a julho de 1984. Os resultados encontrados por BRANDÃO (1985) dão suporte à idéia de que a política monetária afeta o termo doméstico de troca agricultura-indústria e à hipótese de que os preços agrícolas são mais flexíveis do que os preços industriais. BRANDÃO \& ORDEN (1993) reexaminaram a evidência encontrada por BESSLER (1984) e BRANDÃO (1985) e estederam sua análise para considerar um período mais recente. $^{8}$

BARROS (1990) investigou, entre outras coisas, os efeitos de mudanças nos fatores macroeconômicos externos e internos sobre o termo doméstico de troca agricultura-indústria. A análise empírica desse autor baseou-se num modelo teórico e abrange o período de 1973 a 1987. Este autor considerou um conjunto de 8 variáveis, das quais 4 externas (índices de preços do petróleo, de alimentos e de matérias-primas agrícolas e o índice de preço por atacado dos Estados Unidos da América - EUA) e 4 internas (indices de preços por atacado agrícola e industrial, taxa de câmbio real efetiva e oferta monetária (M1)). Dentre os principais resultados encontrados por esse autor, destacam-se: a política monetária afeta muito pouco os preços domésticos agrícola e industrial e os choques cambiais exercem efeitos substanciais nesses preços.

BURNQUIST (1992) investigou, teórica e empiricamente, se os preços agrícolas respondem mais rápido e/ou mais intensamente, no curto prazo, a choques monetários, quando comparados a outros preços na economia. $\mathrm{O}$ estudo utilizou dados trimestrais abrangendo o periodo de 1970 a 1985 e compara dois modelos: um modelo reduzido com apenas três variáveis (oferta monetária, preço agrícola e preço industrial) e um outro modelo em que é acrescentada a taxa de câmbio. Os resultados, de modo geral, indicam que os preços agrícolas respondem, no curto prazo, mais intensamente do que

\footnotetext{
${ }^{8}$ Esse periodo mais recente vai de janeiro de 1970 a setembro de 1992. Os resultados obtidos por BRANDÃO \& ORDEN (1993) corroboram, de modo geral, a evidência empírica encontrada anteriormente por BESSLER (1984).
} 
os preços industriais a um choque na taxa de câmbio e que os efeitos dos choques na oferta monetária são bem menos acentuados.

O presente estudo também investiga, teórica e empiricamente, os efeitos de políticas monetárias e cambiais sobre o preço relativo agricultura-indústria. A análise empírica limita-se ao período de outubro de 1982 a dezembro de 1988. Delimitou-se o início desse período tendo em vista que no quarto trimestre de 1982 o Brasil teve que recorrer ao programa de ajustamento do FMI, em razão do esgotamento de suas reservas e da limitação da oferta externa de crédito. Os fluxos voluntários de capitais externos para países em desenvolvimento praticamente esgotaram-se logo após a decretação da moratória do México, em setembro de 1982. Esse período de ajustamento da economia brasileira à crise da dívida externa é de particular interesse desta pesquisa.

A mudança do regime cambial em março de 1990, ou seja, a passagem de um regime de monopólio de compra e venda de divisas por parte do Banco Central para um regime com maior flexibilidade cambial, delimitaria o período final da análise empírica. Entretanto, excluiu-se o ano de 1989 e o início de 1990, pois nesse período houve um crescimento relativamente acelerado de preços. Períodos de maior instabilidade ou em que há mudanças de regime na economia podem trazer problemas para a estabilidade dos parâmetros estimados e/ou para a determinação da ordem de integração das variáveis e, dessa forma, tornar a análise empírica menos consistente.

Na Figura 1 mostra-se a evolução dos índices da taxa de câmbio real efetiva e do preço relativo agricultura-indústria ${ }^{9}$ no período de interesse desse estudo. Considerou-se a mesma base para efeito de comparação, ou seja, março/85=100. A razão para a escolha dessa base é que há diversas evidências que apontam que em 1985 a taxa de câmbio esteve relativamente alinhada com a competitividade externa do país, entre as quais citam-se o balanço de pagamentos equilibrado e o baixo ágio do dólar no

\footnotetext{
9 O índice do preço relativo agricultura-indústria é a razão entre os índices de preços por atacado agricola e industrial e o índice da taxa de câmbio real efetiva foi calculado considerando-se uma cesta de 7 moedas. Os dados básicos foram obtidos do banco de dados Conjuntura Eletrônica da Fundação Getúlio Vargas.
} 
paralelo. ${ }^{10}$ Março, por sua vez, é o mês em que começa a colheita de grandes safras e os preços agrícolas não estão nem no seu pico nem no seu ponto de mínimo.

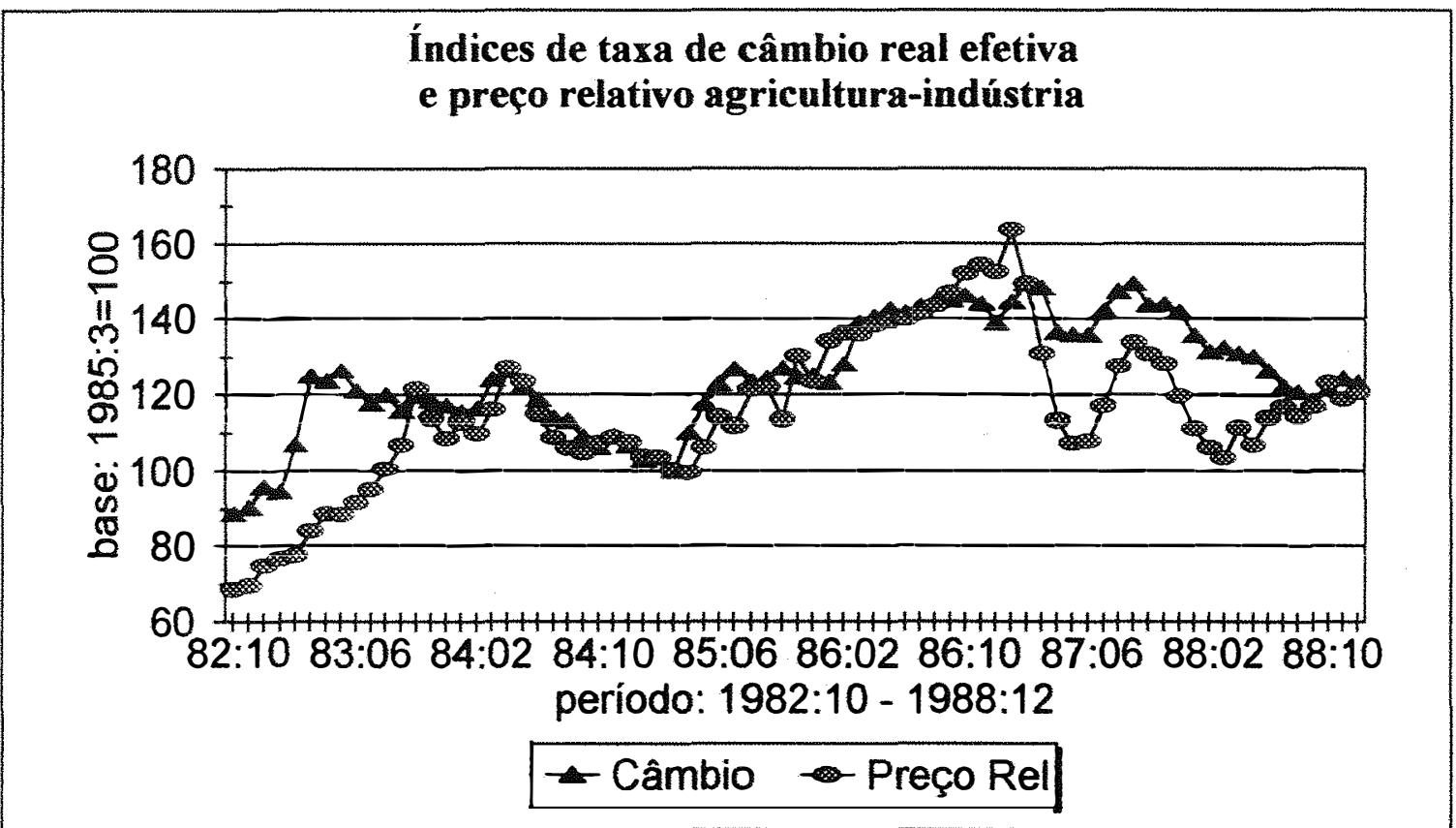

Figura 1 - Índices da taxa de câmbio real efetiva e do preço relativo agricultura-indústria, período outubro/82 a dezembro/88.

Fonte: Dados básicos da Fundação Getúlio Vargas.

Verifica-se, na Figura 1, uma mudança acentuada do preço relativo agricultura-indústria no periodo considerado. Este índice variou desde um mínimo de 68,52 , em outubro de 1982, até um máximo de 163,71, em janeiro de 1987. Outro fato relevante é a alta correlação entre os dois índices, ou seja, o índice do preço relativo tendeu a acompanhar de perto o índice da taxa de câmbio real efetiva, principalmente no período que vai de setembro de 1983 a setembro de 1986. Note-se também que o período em que $\mathrm{o}$ índice do preço relativo atingiu valores mais altos coincide com o

\footnotetext{
${ }^{10}$ Ver ZINI JR. (1993, p.33). Note-se que qualquer outra base poderia ter sido utilizada, pois o que se quer destacar (mudança acentuada do preço relativo agricultura-indústria e a alta correlação deste preço com a taxa de câmbio real) teria sido também evidenciado da mesma forma.
} 
período de vigência do Plano Cruzado (ano de 1986), período este em que ocorreu um crescimento acentuado da oferta de moeda (remonetização da economia).

Desenvolve-se, neste estudo, um modelo teórico para investigar os efeitos de políticas monetárias e cambiais sobre o preço relativo agricultura-indústria. Além da análise dos efeitos de choques cambiais sobre esse preço relativo, investigam-se duas formas alternativas de condução da política monetária: uma considera a taxa de juros endógena, ou seja, esta taxa é determinada dentro do modelo, e a outra considera que as autoridades monetárias fixam essa taxa e deixam endógenos tanto o estoque de moeda quanto o volume de títulos públicos na economia. Alguns analistas da economia brasileira admitem que o Banco Central tenha conduzido a política monetária fixando a taxa de juros. A seguinte passagem de PASTORE (1990, p.499) enfatiza esse ponto:

"Uma proposição que se transformou em ortodoxia na prática da política econômica, no Brasil, é que o Banco Central deve limitar-se a prender a taxa real de juros em um nível positivo razoável, alterando a taxa nominal somente quando a inflação se modificar."

SENNA (1994, p. 143) também é claro a este respeito:

“(..) é praticamente impossível o controle monetário independente no Brasil. Diante desse quadro, qual o papel do Banco Central? Ora, tendo de abrir mão do comando sobre a quantidade de moeda, resta-lhe atuar sobre o nível das taxas de juros."

Dada a importância do aspecto institucional para a condução da política monetária no País, este estudo buscou investigar empiricamente se o fato de se considerar a taxa de juros numa posição mais exógena na matriz de interações contemporâneas dos modelos de auto-regressão vetorial causaria mudanças na resposta do preço relativo agricultura-indústria quando as demais variáveis fossem submetidas a choques. A inclusão da taxa de juros tanto na análise teórica quanto empírica constitui a 
principal contribuição deste estudo em relação aos trabalhos citados anteriormente para a economia brasileira na mesma linha desta pesquisa. Adicionalmente, são utilizadas técnicas econométricas mais recentes que permitem uma melhor especificação (número de defasagens, por exemplo) dos modelos empíricos. ${ }^{11}$

\subsection{Objetivos}

O objetivo principal deste estudo é investigar, teórica e empiricamente, os efeitos de políticas monetárias e cambiais sobre o preço relativo agricultura-indústria, no período de outubro de 1982 a dezembro de 1988.

Especificamente, pretende-se:

a) formular um modelo teórico que permita analisar os efeitos de políticas monetárias e cambiais sobre o termo doméstico de troca agricultura-indústria;

b) estimar a proporção da variância de previsão do preço relativo agricultura-indústria atribuível aos choques monetários, cambiais e na taxa nominal de juros; e

c) estimar a resposta deste preço relativo a estes mesmos choques.

Uma análise dessa natureza, ou seja, que investiga os impactos de políticas monetárias e cambiais sobre o preço relativo agricultura-indústria contribui para uma melhor compreensão da inter-relação entre a política macroeconômica e a agricultura. Além disso, esse tipo de investigação fornece subsidios e informações que poderão ser úteis para uma possível harmonização entre as políticas macroeconômica e

\footnotetext{
11 BESSLER (1984) e BARROS (1992), por exemplo, estimaram modelos VAR com 13 e 12 defasagens, respectivamente, e utilizaram o teste de razão de verossimilhança para definir essas defasagens. Estudos mais recentes têm utilizado outros critérios como, por exemplo, o critério de informação de AKAIKE, para estabelecer o número de defasagens nos modelos VAR e estes modelos têm sido estimados com um número bem menor de defasagens. Ver, por exemplo, WILLIAMS \& BEWLEY (1993) que analisam preços agrícolas e consideram um modelo VAR com duas defasagens.
} 
agrícola. Uma política macroeconômica que penalize a setor agrícola, por exemplo, poderia vir acompanhada de alguma medida compensatória para esse setor.

\subsection{Organização do estudo}

Este estudo está organizado em 5 capítulos. No próximo capítulo faz-se uma breve análise do contexto econômico brasileiro nos anos oitenta e dos aspectos institucionais mais relevantes relativos à implementação das políticas monetárias e cambiais. No capítulo 3 formula-se um modelo teórico para investigação dos efeitos de políticas monetárias e cambiais sobre o preço relativo agricultura-indústria, modelo este que é utilizado para fundamentar a análise empírica desenvolvida no capítulo 4 . Finalmente, no capítulo 5, apresentam-se as principais conclusões deste estudo. 


\section{CRISE DO SETOR EXTERNO E AJUSTE MACROECONÔMICO}

\subsection{Introdução}

Neste capítulo apresentam-se mais informações sobre o contexto econômico brasileiro nos anos oitenta que é marcado, em grande parte, por tentativas de ajuste à crise de dívida externa. Nesta seção comentam-se os planos de estabilização que foram implementados nesse período e mostram-se alguns indicadores macroeconômicos. Nas seções seguintes são fornecidos mais detalhes sobre as políticas monetárias e cambiais desses planos de estabilização, descreve-se a estrutura de intermediação financeira nacional e discutem-se alguns aspectos da política agrícola.

Como já comentado no capítulo anterior, foram utilizadas duas estratégias macroeconômicas distintas de ajuste para enfrentar a crise em que se encontrava a economia brasileira. Essas estratégias buscaram reequilibrar as contas externas e reduzir a inflação. Entretanto, na primeira estratégia (período 1982/84), as políticas adotadas foram recessivas, enquanto que, na segunda estratégia (periodo 1986/89), foram implantados planos não-recessivos de estabilização, ou seja, nesta estratégia buscou-se reduzir a inflação de forma tal a minimizar seus custos para a sociedade.

Foram adotadas, na primeira estratégia de estabilização, as seguintes medidas econômicas, de acordo com a tradição dos programas de ajuste ortodoxo: a) depreciação da taxa de câmbio real; b) redução do déficit público; c) corte nos salários reais; e d) política monetária contracionista. Este conjunto de medidas, além de procurar 
reduzir a inflação, buscou também gerar superávits comerciais elevados para garantir o pagamento do serviço da dívida externa.

Essas medidas agravaram a recessão em 1983: o produto interno bruto (PIB) caiu, nesse ano, 3,4\% (ver tabela 1). O déficit público foi reduzido de 7,3\% do PIB em 1982 para 2,5\% em 1984 e os salários tiveram um declínio em termos reais. O setor externo, por outro lado, teve um desempenho extraordinário: saiu-se de um déficit em transações correntes de 16,3 bilhões de dólares em 1982 para um equilíbrio em 1984. O nível de reservas internacionais aumentou: passou de 2,6 bilhões de dólares em 1982 para 10,2 bilhões de dólares em 1984 .

Tabela 1 - Principais indicadores da economia brasileira, 1980/89

\begin{tabular}{lccccccc}
\hline Ano & $\begin{array}{c}\text { PIB (\%) } \\
\text { taxa } \\
\text { crescim. }\end{array}$ & $\begin{array}{c}\text { Deflator } \\
(\%)\end{array}$ & $\begin{array}{c}\text { Déficit } \\
\text { público } \\
\text { (\%) PIB }\end{array}$ & $\begin{array}{c}\text { Investi- } \\
\text { mento } \\
(\%) \text { PIB }\end{array}$ & $\begin{array}{c}\text { Conta } \\
\text { Corrente } \\
\text { (US\$ bil.) }\end{array}$ & $\begin{array}{c}\text { Nível de } \\
\text { Reservas } \\
\text { (US\$ bil.) }\end{array}$ & $\begin{array}{c}\text { Dívida } \\
\text { Externa } \\
\text { (US\$ bil.) }\end{array}$ \\
\hline 1980 & 9,2 & 90 & - & 22,9 & $-12,8$ & 6,9 & 70,2 \\
1981 & $-4,4$ & 107 & 6,2 & 21,0 & $-11,7$ & 7,5 & 80,0 \\
1982 & 0,6 & 105 & 7,3 & 19,5 & $-16,3$ & 2,6 & 91,3 \\
1983 & $-3,4$ & 140 & 4,2 & 16,9 & $-6,8$ & 3,2 & 97,3 \\
1984 & 5,3 & 213 & 2,5 & 16,3 & 0,0 & 10,2 & 103,5 \\
1985 & 8,0 & 232 & 4,4 & 16,4 & 0,0 & 7,7 & 105,0 \\
1986 & 7,5 & 146 & 3,6 & 18,7 & $-5,3$ & 6,6 & 111,0 \\
1987 & 3,6 & 204 & 5,7 & 17,9 & $-1,4$ & 7,5 & 121,0 \\
1988 & $-0,1$ & 648 & 4,8 & 17,0 & 4,9 & 9,1 & 112,0 \\
1989 & 3,2 & 1323 & 6,9 & 16,7 & 1,2 & 9,0 & 110,0 \\
\hline
\end{tabular}

Fonte: IBGE (Contas Nacionais) e Banco Central.

Nota: O deflator implícito do PIB é utilizado como medida da inflação.

O ajuste externo foi obtido às custas da redução na demanda interna e da mudança nos preços relativos em direção aos bens comercializáveis. ${ }^{1}$ Esta redução na absorção doméstica deveu-se, basicamente, à contração do investimento, que caiu de 19,5\% do PIB em 1982 para 16,3\% em 1984 (ver tabela 1). A mudança nos preços

\footnotetext{
' Ver DALL'ACQUA (1992).
} 
relativos resultou da depreciação da taxa de câmbio real e do surgimento de condições mais favoráveis no mercado externo.

A política monetária restritiva, utilizada para inibir a demanda interna, elevou a taxa de juros interna, que, por sua vez, levou a um crescimento acentuado da dívida mobiliária interna federal em valores reais. Com a redução da absorção doméstica, foi possível obter superávits comerciais elevados, o que viabilizou a transferência de recursos ao exterior. Entretanto, estes superávits comerciais elevados foram obtidos, em parte, devido à contenção das importações, que estiveram sujeitas, ao longo da década de 80 , a controles administrativos. ${ }^{2}$

Não obstante o êxito obtido no ajuste externo, a estratégia de estabilização ortodoxa não conseguiu controlar a inflação, que aumentou de $105 \%$ em 1982 para $213 \%$ em 1984 (ver tabela 1) e acentuou o desequilíbrio interno. Os custos sociais dessa estratégia foram elevados e levaram ao surgimento de pressões para mudanças nas medidas de ajuste macroeconômico.

Novos programas de estabilização, conhecidos como planos de ajuste heterodoxo, foram implementados na segunda metade da década de 80 . Realizaram-se três tentativas de ajuste nesta linha: Plano Cruzado, Plano Bresser e Plano Verão. Estes programas visaram reduzir a inflação de forma drástica, sem grandes efeitos recessivos e distributivos. O diagnóstico do processo inflacionário desses planos era similar, ou seja, identificava-se no componente inercial uma das principais causas da inflação

Desde que a taxa de inflação tenha atingido níveis relativamente elevados, os mecanismos formais e informais de indexação tendem a perpetuar, por inércia, as taxas de inflação observadas nos periodos anteriores. O predomínio desse componente inercial aumenta os custos do ajustamento; torna-se necessário, portanto, um tratamento

${ }^{2}$ Ver ZINI JR. (1990). 
de choque que quebre a inércia e elimine a indexação. Na prática, este choque consistiu no congelamento de preços, salários e taxa de câmbio nominal.

O Plano Cruzado consistiu na primeira tentativa heterodoxa de ajuste. Este programa foi posto em prática em fevereiro de 1986 e dentre suas principais medidas destacam-se: o congelamento de preços, salários e taxa de câmbio nominal e uma reforma monetária que substituiu o padrão monetário cruzeiro por uma nova moeda, o cruzado. Com a queda da inflação, devido ao congelamento de preços e salários, a demanda por moeda aumentou, o que possibilitou a remonetização da economia. Durante este programa, as políticas monetária e fiscal foram expansionistas.

Houve uma resposta favorável da economia durante os seis primeiros meses de vigência do Plano Cruzado. O PIB cresceu 7,5\% em 1986 e houve uma queda da inflação de 232\% em 1985 para 146\% em 1986 (ver tabela 1). Os salários reais aumentaram, assim como o nível de emprego. Entretanto, o aumento da demanda interna agravou a crise do balanço de pagamentos: o déficit em transações correntes aumentou 5,3 bilhões de dólares no período 1985/86.

Devido ao fato da taxa de câmbio nominal ter sido mantida fixa, houve uma apreciação da taxa de câmbio real. As reservas tiveram uma forte queda em 1985, que continuou em 1986, como conseqüência de sua utilização para financiar os déficits em transações correntes. Esta queda acentuada do nivel das reservas forçou o governo a decretar a moratória da dívida externa no começo de 1987. O déficit público, por sua vez, continuou elevado. No final de 1986, com o fim do congelamento de preços e salários, a inflação aumentou rapidamente, atingindo níveis superiores a $20 \%$ mensais.

Em junho de 1987 foi posto em prática o Plano Bresser com o propósito de conter a inflação. ${ }^{3}$ Entre as medidas deste programa destacam-se: a desindexação parcial e o congelamento temporário de preços. Não se fixou a taxa de câmbio nominal e a política salarial foi modificada. $O$ plano adotou a meta (não cumprida) de reduzir 0

${ }^{3}$ Ver, por exemplo, BRESSER PEREIRA (1988) para uma análise dos Planos Cruzado e Bresser. 
déficit público. Dentre os resultados favoráveis deste plano destacam-se: a recuperação da situação externa e a eliminação do risco de uma hiperinflação.

Em 1988 suspendeu-se a moratória externa e procurou-se regularizar os pagamentos internacionais. $\mathrm{O}$ saldo em conta corrente, nesse ano, foi bastante favorável. Entretanto, houve uma aceleração da inflação. Foi posto em prática, então, a terceira tentativa de ajuste heterodoxa (Plano Verão), em janeiro de 1989. Neste programa, congelaram-se os preços, os salários e a taxa de câmbio nominal, desindexou-se a economia e fez-se uma nova reforma monetária (substituição da moeda). Novamente, com o descongelamento dos preços e salários, a inflação voltou a se acelerar.

\subsection{Estrutura de intermediação financeira nacional ${ }^{4}$}

Esta análise do sistema financeiro contribuirá para um melhor entendimento da política monetária. Há certas peculiaridades no sistema financeiro brasileiro quando comparadas ao de outros países com instituições mais evoluídas (por exemplo, Suíça e Alemanha) que dificultam o controle da moeda. Em particular, o Banco Central brasileiro não dispõe de condições para pôr em prática uma política monetária independente e isso, de certa forma, dificulta o controle da inflação.

Nas economias modernas, o sistema financeiro consiste em um conjunto de mercados e instituições especializadas na intermediação de recursos. Esta intermediação ocorre porque existem agentes econômicos (indivíduos, empresas ou governo) deficitários que procuram antecipar seus recursos futuros para o presente e agentes superavitários que desejam transferir recursos para o futuro. $O$ sistema financeiro permite e facilita esta ligação entre o presente e o futuro na economia.

$\mathrm{Da}$ interação entre as curvas de ofertas e de demandas pelos diversos tipos de recursos e para várias maturidades, determina-se o espectro de taxas de juros ou

\footnotetext{
${ }^{4}$ Esta seção baseia-se, em grande parte. em MARTONE et alii (1986).
} 
os termos em que podem ser feitas as transferências intertemporais de recursos. Esse mecanismo de intermediação de recursos materializa-se sob a forma de uma variedade de ativos ou títulos existentes no mercado. Os ativos financeiros, sendo reservas de valor, permitem adiar decisões de consumo e investimento para o futuro.

As instituições financeiras são responsáveis pela captação de recursos junto aos agentes superavitários, sob várias formas e vários prazos, e pelo empréstimo (concessão de crédito) aos agentes deficitários. Pode-se dividir o sistema financeiro em dois segmentos distintos: o sistema monetário ou bancário, que compreende as intituições que criam moeda (autoridades monetárias e bancos comerciais), e o sistema não-monetário, que inclui todos os demais tipos de intermediários financeiros nãobancários.

Num sistema bancário típico, as autoridades monetárias emitem a moeda primária da economia (base monetária) e os bancos comerciais criam a moeda secundária, por meio da captação (depósitos à vista) e do empréstimo de recursos. Entre as funções básicas do sistema bancário estão prover os serviços de pagamentos à economia e criar crédito. Esta segunda função (criação de crédito) do sistema bancário é também realizada por instituições não-bancárias.

A fiscalização e a regulagem do sistema financeiro têm sido atribuídas, em geral, ao Banco Central. Esta regulagem é feita tradicionalmente por meio das políticas monetária e financeira do governo e da regulamentação de mercado. A política monetária (num conceito restrito) ${ }^{5}$ consiste na manipulação da base monetária (criação ou destruição de moeda primária) e o tipo mais importante de política financeira é a administração da dívida pública. Estas políticas afetam o fluxo de crédito e as taxas de juros, que, por sua vez, afetam as decisões de consumo e investimento dos agentes econômicos. A regulamentação de mercado define o contexto legal da atividade financeira.

\footnotetext{
${ }^{5}$ Na próxima seção deste capítulo será dado um conceito mais amplo de política monetária.
} 
O sistema financeiro brasileiro atual foi estruturado no biênio 1964/65, com a promulgação de três leis principais: Lei 4.380 , que instituiu a correção monetária; Lei 4.595, que estabeleceu a reforma bancária, criando-se o Conselho Monetário Nacional (CMN) e o Banco Central (BACEN); e Lei 4.728, que disciplinou o mercado de capitais. Antes dessa reforma financeira, a estrutura de intermediação no País era formada pelos bancos comerciais e por algumas instituições isoladas que foram surgindo de forma espontânea, de acordo com as necessidades do mercado.

Essa reforma do sistema financeiro brasileiro possibilitou o aumento e a diversificação do número de intermediários financeiros não-bancários, que passaram a ter áreas bem específicas de atuação. Ao mesmo tempo, foram ampliadas as opções de ativos aos poupadores. Note-se que não só as instituições financeiras emitem títulos, mas também as empresas e o governo, que os vendem diretamente no mercado. As ações e debêntures emitidas pelas empresas abertas são ativos não-financeiros.

$\mathrm{Na}$ Figura 2 apresenta-se, esquematicamente, o sistema financeiro brasileiro. Utilizou-se como critério para agrupar as instituições o conceito convencional de moeda. ${ }^{6}$ O sistema foi subdividido em dois subsistemas: o monetário e o nãomonetário. Dividiram-se as instituições do sistema monetário em dois grupos: as autoridades monetárias e os bancos comerciais. Dentro do sistema não-monetário estão todas as instituições não-bancárias de intermediação financeira. As Caixas Econômicas, cujos depósitos à vista integram o conceito de moeda, ocupam uma posição mista.

O CMN é a entidade máxima do sistema financeiro brasileiro. Além de suas funções normativas, cabe a este orgão estabelecer as diretrizes e metas das políticas monetária, creditícia e cambial do País. Seu principal órgão executivo é o BACEN. Este órgão tem como atribuições: receber depósitos compulsórios e fornecer redescontos, regular a expansão dos meios de pagamento, financiar o Tesouro Nacional mediante a

\footnotetext{
${ }^{6}$ Meios de pagamento, M1, que corresponde ao papel-moeda em poder do público mais depósitos à vista no sistema bancário.
} 
colocação de títulos públicos, administrar as dívidas públicas interna e externa, e administrar e receber depósitos das reservas internacionais do País.

Há certas peculiaridades do BACEN que não são próprias de bancos centrais independentes. Por exemplo, a existência de vínculos operacionais entre este e o Tesouro Nacional, através da conta movimento, mecanismo este que permitiu ao Tesouro, até 1986, contrair empréstimos junto ao BACEN, por meio do Banco do Brasil, a custo desprezível e de maneira praticamente ilimitada; ${ }^{7}$ os compromissos assumidos pelo BACEN relativos ao endividamento externo, que são, na verdade, obrigações do Tesouro; e as operações com fundos e programas especiais. ${ }^{8}$

Os agentes que operam no mercado financeiro podem ser divididos em quatro grupos: as autoridades monetárias, os bancos comerciais, os intermediários financeiros não-bancários e o público não-financeiro. Apresentam-se a seguir os balancetes consolidados das autoridades monetárias e do público não-financeiro. ${ }^{9} \mathrm{O}$ Banco do Brasil foi considerado autoridade monetária até a reforma de 1986. Dessa forma, considera-se no balancete das autoridades monetárias os depósitos à vista.

\footnotetext{
Segundo SENNA (1994), essa vinculação entre o BACEN e o Tesouro Nacional ainda existe, e o fim da conta movimento, em 1986, representou apenas uma troca de procedimentos, ou seja, o automatismo daqueles empréstimos foi substituído por um mecanismo de solicitação formal de recursos.

${ }^{8}$ Estas operações e estes programas especiais, que vêm diminuindo desde a reforma de 1986, conferiram ao BACEN a característica peculiar de gestor de volume apreciável de recursos oficiais.

${ }^{9}$ Ver, por exemplo, SIMONSEN \& CYSNE (1989) para mais detalhes sobre os balancetes consolidados dos gnupos de agentes que operam no mercado financeiro.
} 


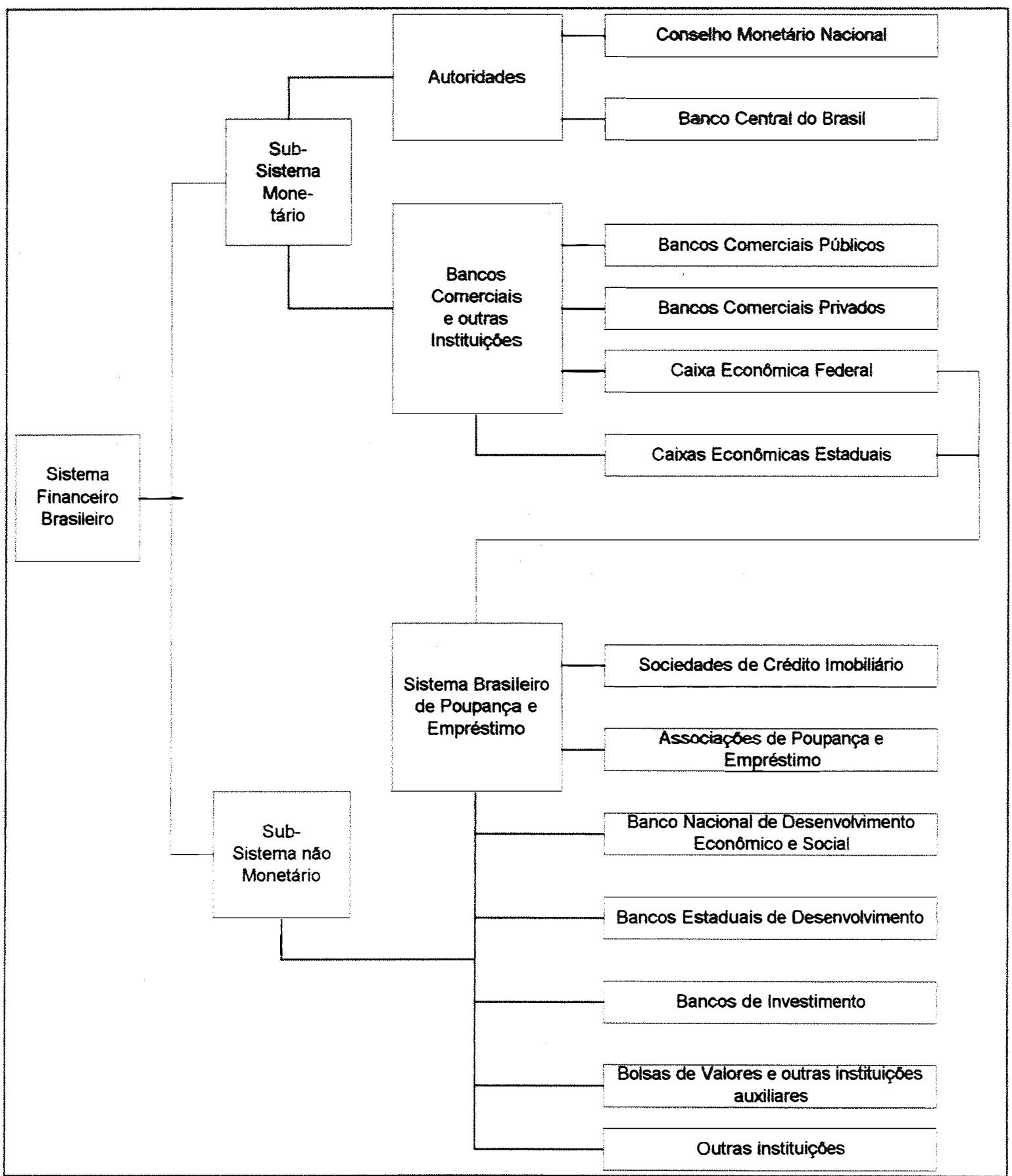

Figura 2 - Representação esquemática do sistema financeiro brasileiro.

Fonte: LOPES \& ROSSETTI (1993, p. 327). 
Na Tabela 2 apresenta-se um balancete sumário das autoridades monetárias. No lado do ativo, dividiram-se os ativos em externos e domésticos, conforme o setor a que se destinam. As operações ativas das autoridades monetárias injetam moeda na economia. No lado do passivo, separou-se a base monetária do passivo não-monetário. O passivo não-monetário inclui depósitos a prazo, depósitos do Tesouro Nacional, depósitos em moeda estrangeira e outros recursos.

Tabela 2 - Balancete consolidado das autoridades monetárias

\begin{tabular}{ll}
\hline Ativo & Passivo \\
\hline Reservas Internacionais (F) & Base Monetária (B) \\
Crédito Doméstico (C) & a) Papel Moeda em Poder do Público (PP) \\
a) ao Governo (CG) & b) Depósitos à Vista (D1) \\
b) ao Sistema Financeiro (CS) & c) Reservas Bancárias (RB) \\
c) ao Público (CP) & Passivo Não-Monetário (N) \\
\hline
\end{tabular}

Fonte: MARTONE et alii (1986).

As seguintes identidades podem ser definidas a partir do balancete consolidado das autoridades monetárias:

$$
\begin{aligned}
& \mathrm{B}=\mathrm{PP}+\mathrm{D} 1+\mathrm{RB} \\
& \mathrm{C}=\mathrm{CG}+\mathrm{CS}+\mathrm{CP} \\
& \mathrm{B}+\mathrm{N}=\mathrm{F}+\mathrm{C}
\end{aligned}
$$

A equação (3) pode ser reescrita da seguinte forma:

$$
\mathrm{B}=\mathrm{F}+(\mathrm{C}-\mathrm{N})
$$

Esta equação mostra que a evolução da base monetária está ligada às mudanças nas reservas internacionais e no crédito doméstico líquido (C-N). Como as autoridades governamentais não mantêm um controle direto sobre o nivel de reservas internacionais, a política monetária requer um controle rígido do crédito doméstico líquido. 
O estoque de meios de pagamento é dado por:

$$
\mathrm{M} 1=\mathrm{PP}+\mathrm{D} 1+\mathrm{D} 2
$$

em que

$$
\text { D2 = depósitos à vista nos bancos comerciais. }
$$

A relação entre os meios de pagamento e a base monetária é dada pela seguinte expressão:

$$
\mathrm{M} 1=\mathrm{kB}
$$

em que

$\mathrm{k}=$ multiplicador dos meios de pagamento.

Este parâmetro depende do comportamento do público não-financeiro e do nível das reservas bancárias.

Na Tabela 3 apresenta-se o balancete consolidado do setor privado nãofinanceiro.

Tabela 3 - Balancete consolidado do setor privado não-financeiro

\begin{tabular}{ll}
\hline Ativo & Passivo \\
\hline Meios de Pagamento (M1) & Empréstimos Bancários (CP+EB) \\
Títulos do Governo (TG) & Empréstimos Não-Bancários (EN) \\
Títulos Privados (TP) & Empréstimos Externos (EX) \\
Capital Físico (KF) & Patrimônio Líquido (PL) \\
Ativos em Moeda Estrangeira (AE) & \\
\hline
\end{tabular}

Fonte: MARTONE et alii (1986).

Nota: (*) Inclui os hoardings de dólares, ouro e depósitos de agentes no exterior.

A posição do público não-financeiro, com base na Tabela 3, pode ser resumida pela seguinte expressão:

$$
\mathrm{M} 1+\mathrm{TT}+\mathrm{KF}+\mathrm{AE}=\mathrm{CP}+\mathrm{EE}+\mathrm{PL}
$$




$$
\begin{aligned}
& \mathrm{TT}=\mathrm{TG}+\mathrm{TP} \text { e } \mathrm{EE}=\mathrm{EB}+\mathrm{EN}+\mathrm{EX} \\
& \mathrm{EB}=\text { Empréstimos dos bancos comerciais ao público; } \\
& \mathrm{EN}=\text { Empréstimos dos intermediários financeiros não-bancários ao }
\end{aligned}
$$

público.

Uma importante generalização pode ser feita a partir dos balancetes consolidados dos quatro grupos de agentes que operam no mercado financeiro. Consolidando o sistema financeiro (sistema bancário mais intermediários financeiros nãobancários) ao público não-financeiro, obtém-se o balancete consolidado da economia como um todo, excluído o governo: ${ }^{10}$

$$
(F+A E)+(C G+G G)+K F=N^{*}+(C X+E X)+P L
$$

em que

$$
\mathrm{GG}=\mathrm{GB}+\mathrm{GN} \text { e } \mathrm{CX}=\mathrm{C} 1+\mathrm{C} 2
$$

GB = Títulos do governo em poder dos bancos comerciais;

GN = Títulos do governo em poder dos intermediários financeiros nãobancários;

$\mathrm{C} 1=$ Repasses externos aos bancos comerciais; e

C2 = Repasses externos aos intermediários financeiros não-bancários.

Com base na equação (8), podem-se dividir os ativos da economia em três grupos: ativos contra o resto do mundo em moeda estrangeira $(F+A E)$, ativos contra $o$ governo $(\mathrm{CG}+\mathrm{GG})$ e ativos físicos $(\mathrm{KF})$. O passivo da economia consiste no seu endividamento junto ao resto do mundo $(\mathrm{CX}+\mathrm{EX})$, nos recursos do governo nas autoridades monetárias $\left(\mathrm{N}^{*}\right)$ e no patrimônio líquido $(\mathrm{PL})$.

Na tabela 4 apresentam-se dados de três anos (1984, 1986 e 1988) das contas ativas e passivas das autoridades monetárias. Verifica-se, nas contas ativas, que as

\footnotetext{
${ }^{10}$ Por simplicidade, desconsiderou-se a parcela do passivo não-monetário (N) que é um ativo do público não-financeiro (depósitos a prazo no Banco do Brasil, até início de 1986).
} 
operações com o Tesouro Nacional e os haveres externos representaram juntas, em 1988, mais de $90 \%$ destas contas. Essas operações com o Tesouro envolvem títulos federais em carteira do BACEN e operações de crédito da União. O BACEN mantém também um conta única do Tesouro Nacional. Os haveres externos referem-se a ouro, moeda estrangeira e quotas de organismos financeiros.

Tabela 4 - Balancete analítico do Banco Central do Brasil (anos: 1984* , 1986 e 1988) percentagens

\begin{tabular}{|c|c|c|c|c|c|c|c|}
\hline Ativo & 1984 & 1986 & 1988 & Passivo & 1984 & 1986 & 1988 \\
\hline $\begin{array}{l}\text { 1. Crédito a Instituições Fi- } \\
\text { nanceiras }\end{array}$ & 5,88 & 4,84 & 1,12 & 1. Passivo Monetário & 8,31 & 12,61 & 5,37 \\
\hline $\begin{array}{l}\text { 2. Adiantamentos a Fundos } \\
\text { e Programas }\end{array}$ & 2,94 & 0,83 & 0,29 & $\begin{array}{l}\text { 2. Recursos de Fun- } \\
\text { dos e Programas }\end{array}$ & 7,06 & 9,85 & 0,81 \\
\hline $\begin{array}{l}\text { 3. Operações com o Tesou- } \\
\text { ro Nacional }\end{array}$ & 18,30 & 27,54 & 72,85 & 3. Depósitos Diversos & 23,64 & 11,53 & 10,17 \\
\hline $\begin{array}{l}\text { 4. Suprimentos ao Banco do } \\
\text { Brasil p/ Oper. Especiais }\end{array}$ & 11,25 & 21,02 & 6,28 & $\begin{array}{l}\text { 4. Obrigações Exter- } \\
\text { nas }\end{array}$ & 40,64 & 44,70 & 58,90 \\
\hline 5. Haveres Externos & 28,24 & 19,02 & 18,36 & $\begin{array}{l}\text { 5. Letras do Banco } \\
\text { Central }\end{array}$ & 0,00 & 9,63 & 4,77 \\
\hline $\begin{array}{l}\text { 6. Outras Operações, Encar- } \\
\text { gos e Contas }\end{array}$ & 33,39 & 26,75 & 1,10 & 6. Recursos Próprios & 20,35 & 11,68 & 19,98 \\
\hline Total & 100 & 100 & 100 & Total & 100 & 100 & 100 \\
\hline
\end{tabular}

Fonte: Banco Central.

Nota: $\left(^{*}\right)$ Os dados de 1984 referem-se apenas ao mês de dezembro.

As contas ativas mostram que as operações do BACEN com o Tesouro Nacional cresceram ao longo da década de oitenta. ${ }^{11}$ Esse fato ilustra a forte interrelação entre estas duas instituições no Brasil. Outro item importante das contas ativas são os suprimentos ao Banco do Brasil para operações especiais, que incluem, no âmbito agrícola, o crédito rural e a política de estoques reguladores. Este item representou mais

11 Sendo uma das principais aplicações das autoridades monetárias, as operações com o Tesouro Nacional passaram a se constituir na principal fonte de expansão monetária na economia. 
de $20 \%$ das contas ativas do BACEN em 1986, o que evidencia a volta dos incentivos à agricultura, que ocorreu durante o Plano Cruzado.

No passivo do BACEN destacam-se como fonte de recursos às autoridades monetárias os depósitos diversos e as obrigações externas (ver Tabela 4). As obrigações externas incluem, entre outras, recursos do Clube de Paris, depósitos de organismos internacionais, juros retidos e recursos de acordos e convênios. A participação da base monetária (passivo monetário) no passivo do BACEN foi relativamente elevada em 1986, devido à remonetização da economia. Entretanto, esta participação da base caiu em 1988, em função da aceleração da inflação.

\subsection{Política monetária}

A política monetária, de acordo com LOPES \& ROSSETTI (1992, p. 196), pode ser definida como "o controle da oferta de moeda e das taxas de juros, no sentido de que sejam atingidos os objetivos da política econômica global do governo". Uma outra definição citada por esses autores e que se encontra em diversos documentos divulgados pelo Banco Central do Brasil é que a política monetária consiste na "atuação das autoridades monetárias, por meio de intrumentos de efeito direto ou induzido, com o propósito de controlar a liquidez global do sistema econômico".

Os instrumentos tradicionais de controle monetário são o recolhimento compulsório, o redesconto (assistência financeira) e as operações de mercado aberto. No Brasil, além desses instrumentos clássicos de controle monetário, as autoridades monetárias têm utilizado instrumentos pouco convencionais, como controle e seleção de crédito, administração das taxas de juros e persuasão moral. ${ }^{12}$

12 Ver LOPES \& ROSSETTI (1993). 


\subsubsection{Recolhimento compulsório}

O recolhimento compulsório é um instrumento que atua diretamente sobre o nivel de reservas dos bancos comerciais. Essas reservas bancárias são os depósitos que os bancos comerciais mantêm, voluntária ou compulsoriamente, em sua própria caixa ou junto às autoridades monetárias. O total de reservas (taxa de recolhimento sobre os depósitos à vista) que os bancos comerciais devem manter junto ao BACEN afeta, via multiplicador, o volume dos meios de pagamento.

O aumento da taxa das reservas compulsórias que os bancos comerciais devem manter junto ao BACEN reduz a proporção dos depósitos que pode ser convertida em empréstimos, o que leva à contração de M1. Inversamente, a redução da taxa de reservas aumenta as disponibilidades para empréstimos. O multiplicador, neste caso, aumenta, o que leva à expansão dos meios de pagamento.

As taxas das reservas compulsórias têm variado no País em função da região e do tamanho dos bancos. Até 1980 , as taxas de recolhimento eram de $35 \%$ para as regiões mais desenvolvidas e $18 \%$ para as menos desenvolvidas. Os bancos sediados (com sede na própria região) e os não-sediados nas regiôes menos desenvolvidas estariam obrigados a aplicar nessas regiões $60 \%$ e $70 \%$, respectivamente, de seus depósitos à vista. No início de 1981, o BACEN modificou o recolhimento das regiões menos desenvolvidas, classificando os bancos em três categorias, conforme a média de seus empréstimos: ${ }^{13}$

a) bancos pequenos (emprestam menos de 1,7 milhão de Obrigações do Tesouro Nacional - OTNs) - devem recolher de 8 a $30 \%$, dependendo de sua localização;

b) bancos médios (emprestam de 1,7 a 20 milhões de OTNs) - recolhem de 10 a 38\% de depósito compulsório; e

13 Ver MARINHO (1988). 
c) bancos grandes (emprestam acima de 20 milhões de OTNs) - devem recolher de 12 a $46 \%$ de compulsório.

Em setembro de 1982, o CMN autorizou o BACEN a elevar o recolhimento compulsório para até $65 \%$. No mesmo período, foram alterados os limites de recolhimento dos bancos não-sediados. Em junho de 1983, houve nova alteração nos percentuais de recolhimento desses bancos: os bancos médios tiveram seus recolhimentos alterados de 40 para $45 \%$ e os grandes de 45 para $50 \%$; os demais percentuais ficaram inalterados. ${ }^{14}$

A utilização do recolhimento compulsório no Brasil tem apresentado certos desvirtuamentos. Por exemplo, os bancos comerciais compõem suas reservas junto ao BACEN em parte com títulos públicos e em parte com moeda. ${ }^{15}$ Esse instrumento tem sido utilizado também para direcionar o crédito bancário para operações consideradas prioritárias. Nesse sentido, as reservas compulsórias já foram usadas para financiar as pequenas e médias empresas, o crédito educativo e a agricultura.

\subsubsection{Redesconto}

O redesconto é um empréstimo que o BACEN concede aos bancos comerciais para cobrir eventuais problemas de liquidez. Nesse tipo de operação, 0 BACEN funciona como banco dos bancos, descontanto títulos dos bancos comerciais a uma taxa pré-fixada, de forma a atender suas necessidades imediatas de caixa, a curtíssimo prazo. Entretanto, os bancos comerciais podem recorrer ao mercado interbancário, criado com a reforma de 1986, evitando assim o recurso ao redesconto oficial, que é tido como um expediente último e extremado.

\footnotetext{
${ }^{14}$ Idem.

${ }^{15}$ Em termos de reservas compulsórias, essa composição equipara os títulos da dívida pública à moeda.
} 
O controle dos meios de pagamento através do redesconto é feito tradicionalmente por meio da variação das taxas de juros cobradas pelo BACEN. Se a taxa do redesconto aumenta, as reservas bancárias voluntárias aumentam, influindo assim no montante dos empréstimos concedidos pelos bancos comerciais. As outras formas menos tradicionais desse intrumento utilizadas no Brasil são: mudança dos prazos concedidos aos bancos para o resgate dos títulos redescontados, fixação dos limites operacionais ou restrição dos tipos de títulos redescontáveis. ${ }^{16}$

O BACEN estabelece um limite nas operações de redesconto. Este limite é fixado para cada banco comercial por meio de uma percentagem sobre seus saldos médios dos depósitos à vista e a prazo de fim de mês. As operações superiores à taxalimite são chamadas extralimite, e as autoridades monetárias cobram, neste caso, tạxas de juros mais altas. $\mathrm{O}$ redesconto tem sido utilizado também seletivamente para refinanciar operações de longo prazo de interesse do governo. Dentre as atividades beneficiadas com esta operação está a comercialização de safras agrícolas.

\subsubsection{Operações de mercado aberto}

As operações de mercado aberto (open market) consistem na compra e venda de títulos federais da dívida pública. Por meio destas operações, as autoridades monetárias são capazes de administrar a oferta de moeda na economia. Se o BACEN deseja expandir a oferta monetária, por exemplo, realiza operações de resgate dos titulos da dívida pública; com isso, injeta moeda na economia. Caso contrário, ou seja, se deseja o efeito oposto, coloca em circulação títulos federais e retira, no mesmo valor dos títulos vendidos, moeda que se encontrava em circulação.

O mercado aberto é mais flexível quando comparado aos outros dois instrumentos clássicos de controle monetário, ou seja, a fixação de reservas e a

\footnotetext{
${ }^{16}$ Ver LOPES \& ROSSETTI (1993).
} 
concessão de redescontos. Estes dois instrumentos apresentam uma certa dose de rigidez que limita a sua atuação, no curto prazo. Por outro lado, a flexibilidade das operações de mercado aberto se reflete tanto na sua operacionalização quanto na magnitude de suas ações. Além de contribuir para uma dada meta de expansão monetária, o mercado aberto pode ser utilizado também para compensar distúrbios aleatórios nas reservas bancárias.

As operações de mercado aberto foram iniciadas no País em 1968. De 1968 a 1980, o impacto monetário da compra e venda de títulos da dívida pública foi, em geral, contracionista. Entretanto, esses impactos não foram relevantes quando comparados à variação da base monetária no período, caracterizando-se mais pelo aspecto residual. ${ }^{17} \mathrm{Na}$ década de 80 , ao contrário, esse intrumento ganhou importância em função da maior necessidade do governo em operar o serviço da dívida. Nos sete primeiros meses de 1981, por exemplo, o saldo líquido das operações de mercado aberto representou mais de 2,6 vezes o fluxo de base monetária emitido.

Na Tabela 5 apresentam-se dados relativos ao impacto monetário da compra e venda de títulos públicos. Verifica-se que, à exceção dos anos de 1982, $1983 \mathrm{e}$ 1986, o impacto monetário dessas operações foi contracionista. Estes impactos foram maiores nos anos de 1983, 1984 e 1985. Em 1983, o saldo líquido das operações de mercado aberto representou 1,06 vez o volume da base monetária emitido. Em 1986, a remonetização da economia permitiu o resgate maciço de títulos públicos.

Ver LAMY (1987). 
Tabela 5 - Colocação de títulos públicos e base monetária, 1982/88 (NCZ\$ mil)

\begin{tabular}{lccc}
\hline Ano & $\begin{array}{c}\text { Impacto Monetário das } \\
\text { Operações com Títulos } \\
\text { Públicos }\end{array}(1)$ & $\begin{array}{c}\text { Base Monetária } \\
\text { (fluxo no período })\end{array}$ & $(1) /(2)$ \\
\hline 1982 & 76 & $1.042,0$ & 0,07 \\
1983 & 2.289 & $2.148,1$ & 1,06 \\
1984 & -9.829 & $10.647,7$ & 0,92 \\
1985 & -25.689 & $30.725,9$ & 0,84 \\
1986 & 92.530 & $133.154,0$ & 0,69 \\
1987 & -217.049 & $324.636,0$ & 0,67 \\
1988 & -2.364 .835 & $3.133 .469,0$ & 0,75 \\
\hline
\end{tabular}

Fonte: Dados primários do Banco Central.

Nota: $\left({ }^{*}\right)$ Variação da base de dezembro a dezembro, em anos consecutivos.

A elevação das taxas de recolhimento compulsório, na primeira metade da década de 80 , e os impactos contracionistas das operações de mercado aberto, principalmente nos biênios 1983/84 e 1987/88, refletiram-se na elevação das taxas de juros. Na Figura 3 mostra-se a evolução das taxas de juros nominais (taxa de financiamento dos títulos públicos - média composta bruta), no período de outubro de 1982 a dezembro de 1988. Verifica-se que, à exceção do ano de 1986, em que houve congelamento de preços e salários e a política monetária foi expansionista, há uma tendência de crescimento dessa taxa.

Segundo MARTONE et alii (1986), as taxas de juros elevadas, principalmente na primeira metade da década de 80 , resultaram de dois fatores principais: de um lado, a própria estratégia de ajuste da economia, e, de outro, certas características institucionais do sistema financeiro brasileiro, citando como exemplo os mecanismos de administração interna da dívida externa. O déficit público e as taxas de juros elevadas geraram um círculo vicioso na década de 80 , com sérias implicações para a estabilidade e a retomada do crescimento econômico. 


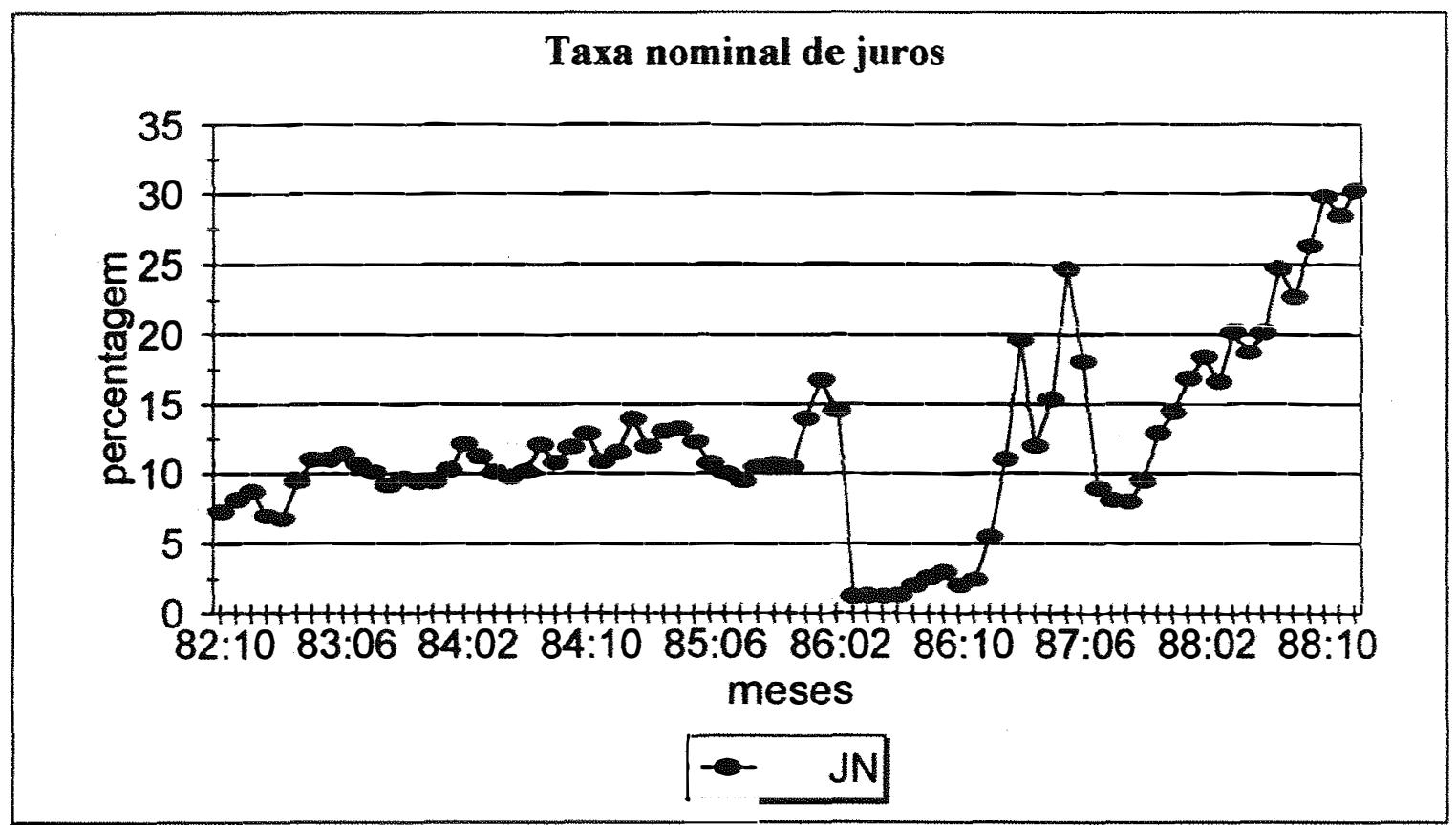

Figura 3 - Evolução da taxa nominal de juros, período outubro/82 a dezembro/88 Fonte: Dados da Fundação Getúlio Vargas.

Os vínculos operacionais existentes entre o BACEN e o Tesouro Nacional constituem-se no principal fator a dificultar o controle da expansão monetária no País. Em vista dessas dificuldades, SENNA (1994) argumenta que resta ao BACEN atuar sobre o nível das taxas de juros. Essa tarefa é feita de duas maneiras: por meio das operações defensivas de mercado aberto, para equilibrar as reservas bancárias, e por meio das operações dinâmicas de administração das taxas de juros. ${ }^{18}$

Na Figura 4 mostra-se a evolução dos meios de pagamento (M1), no período de outubro de 1982 a dezembro de 1988. Esse agregado monetário está mensurado em reais. Verifica-se que os meios de pagamento cresceram a taxas crescentes no período considerado, notadamente a partir de 1987. Em 1986 há um crescimento significativo da oferta real de moeda com a remonetização da economia.

${ }^{18}$ Ver SENNA (1994) para mais detallhes sobre essas operaçòes. 


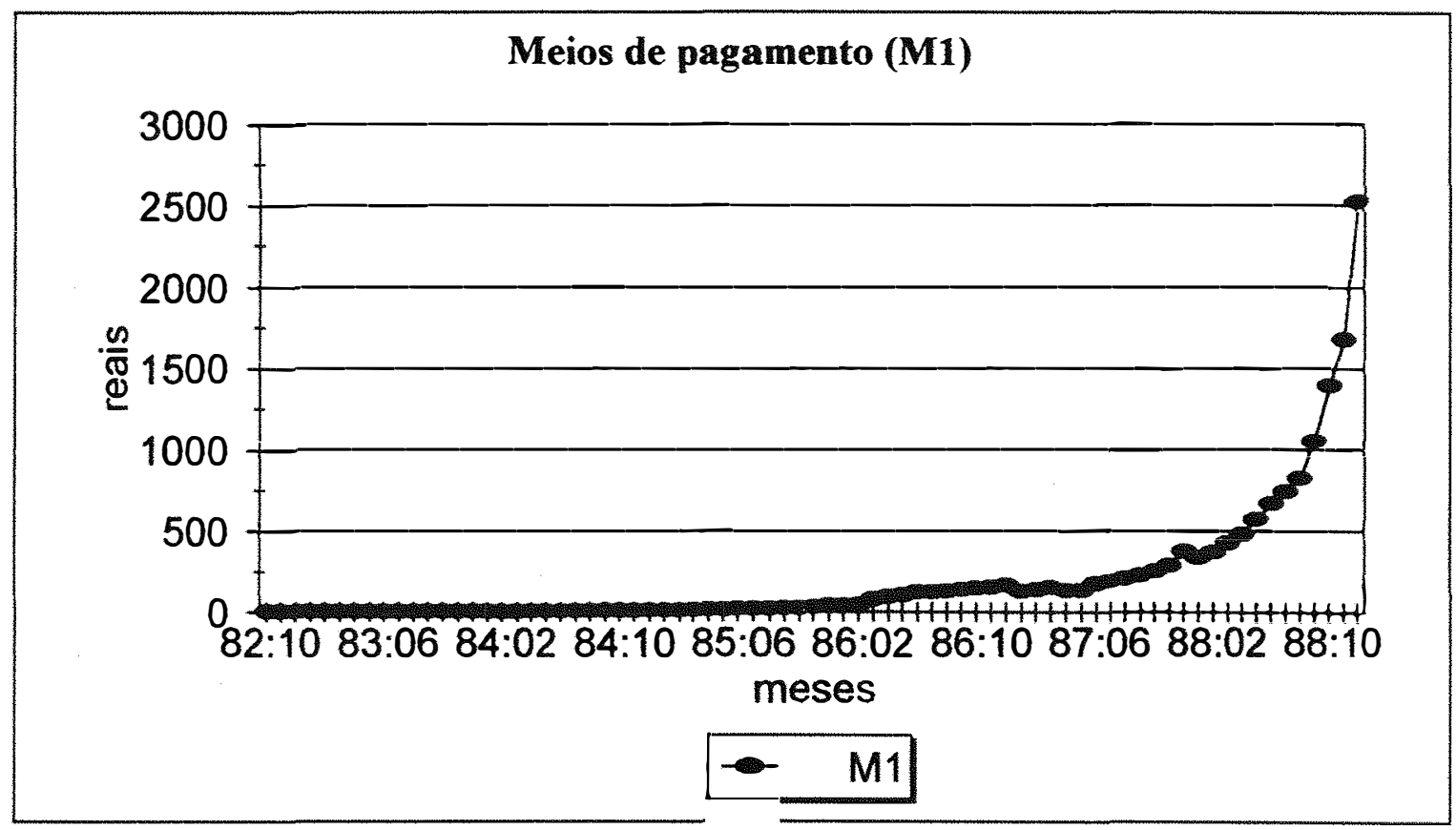

Figura 4 - Evolução dos meios de pagamento (M1), período outubro/82 a dezembro/88. Fonte: Dados básicos da Fundação Getúlio Vargas.

\subsection{Política cambial}

Nas economias de mercado abertas, a taxa de câmbio é um dos principais preços relativos básicos, e sua importância decorre do fato de intermediar as transações da economia doméstica com outros países. Desde que existam bens nãocomercializáveis, seja porque os custos de transações desses bens são elevados ou porque existem restrições à arbitragem internacional, as variações na taxa de câmbio afetam os termos domésticos de troca e, por extensão, a alocação intersetorial de recursos.

Variações cambiais afetam a competitividade entre os diversos setores de uma economia. Uma apreciação da taxa de câmbio (valorização da moeda nacional), por exemplo, reduz a margem de competitividade dos setores exportadores e favorece as importações. O efeito inverso é observado, no caso de uma desvalorização do câmbio. 
Dessa forma, quando a política cambial é parte ativa dos planos de ajustamento, os setores de bens comercializáveis são os mais afetados.

O regime cambial brasileiro caracteriza-se pelo monopólio do câmbio, ou seja, apenas o BACEN pode realizar legalmente transações com divisas estrangeiras ou, eventualmente, autorizar que outros agentes as façam, sob sua fiscalização. ZINI JR. (1993) adverte que a determinação do preço da divisa (a taxa de câmbio) não deve ser confundida com essa noção de monopólio cambial, pois a taxa de câmbio é estabelecida pelo mercado de divisas e pelas intervenções do BACEN. ${ }^{19}$

Diversos sistemas de determinação da taxa de câmbio já foram utilizados no País. De 1968 a fevereiro de 1990, prevaleceu, em seus traços básicos, a política das minidesvalorizações. ${ }^{20}$ Esta política consistia de desvalorizações pequenas e freqüentes da taxa de câmbio nominal em intervalos aleatórios; o critério de corrøção seguia a evolução de um índice de preços doméstico. ${ }^{21}$ Esse critério de correção da taxa de câmbio visava manter a paridade relativa do poder de compra entre a moeda nacional e a moeda estrangeira.

Durante o período da política de minidesvalorizações, houve duas maxidesvalorizações nominais do cruzeiro em relação ao dólar, ambas de $30 \%$ : uma em dezembro de 1979 e a outra em fevereiro de $1983 .{ }^{22}$ Outros aspectos importantes da política cambial foram os congelamentos da taxa de câmbio nominal durante a implantação do Plano Cruzado em 1986 e durante quatro meses do Plano Verão em 1989. Em março de 1990, a taxa de câmbio passou a ser determinada de forma mais flexível. O BACEN, entretanto, ainda intervém no mercado de divisas. ${ }^{23}$

\footnotetext{
19 As leis 4.131/1962, 4.330/1964 e 4.595/1967 estabelecem os controles do mercado de câmbio.

20 Ver ZINI JR. (1993).

${ }^{21}$ Esse critério de correção do câmbio sofreu algumas alterações ao longo do periodo de 1968 a fevereiro de 1990. Ver, por exemplo. ZINI JR. (1993) para mais detalhes.

${ }^{22}$ Em 1987 houve uma mididesvalorização da moeda nacional.

${ }^{23}$ Estas intervenções do BACEN deveriam limitar-se a suavizar as flutuaçooes de curto prazo na taxa de câmbio e a acumular reservas internacionais, segundo metas preestabelecidas.
} 
Nas discussões da política cambial, freqüentemente é mais importante analisar a evolução da taxa de câmbio real. Existem diversos indicadores para esta taxa. ${ }^{24}$ Entre os indicadores mais usados estão a taxa de câmbio real bilateral (por exemplo, real/dólar) e a taxa de câmbio real efetiva. No cálculo desta última taxa, utilizase uma cesta de moeda ponderada pela participação dos principais parceiros comerciais do país. $O$ índice da taxa de câmbio real é obtido do produto da razão entre um índice de preços externo e um índice de preços doméstico com a taxa de câmbio nominal.

Na Tabela 6 apresentam-se dois indicadores da taxa de câmbio real para o periodo 1980/88: a) o índice da taxa de câmbio real bilateral $\left(T C R B=E P^{*} / P\right)$, em que $E=$ índice da variação anual da taxa de câmbio nominal (Cr\$/US\$); $P^{*}=$ índice de preços por atacado dos Estados Unidos da América; e $P=$ índice de preços ao consumidor, no Rio de Janeiro; e b) o índice da taxa de câmbio real efetiva (TCRE), calculado utilizando a mesma fórmula anterior, só que o índice de preços externo foi obtido de uma cesta de moedas ponderada pela participação dos 15 principais parceiros comerciais do Brasil.

Tabela 6 - Indicadores da taxa de câmbio real no Brasil, 1980/88 (base: 1985=100*)

\begin{tabular}{lcl}
\hline Ano & TCRB & TCRE \\
\hline 1980 & 70,59 & 73,95 \\
1981 & 66,20 & 65,75 \\
1982 & 65,89 & 63,29 \\
1983 & 88,70 & 87,03 \\
1984 & 97,16 & 96,00 \\
1985 & 100,00 & 100,00 \\
1986 & 87,31 & 92,60 \\
1987 & 78,18 & 83,56 \\
1988 & 70,95 & 77,39
\end{tabular}

Fonte: ROCHA (1995).

Nota: $\left({ }^{*}\right)$ A base foi alterada de $1980=100$ para $1985=100$.

${ }^{24}$ Ver, por exemplo. ZINI JR. (1993) para uma discussão dos diversos indicadores da taxa de câmbio real. 
Quando o indicador da Tabela 6 se eleva, há uma depreciação real da moeda, e quando diminui, há uma apreciação. Os dois indicadores evidenciam que no início da década de 80 (anos 1981 e 1982) a taxa de câmbio real esteve apreciada. A partir de 1983 a taxa de câmbio real sofre uma forte depreciação que se estende, até atingir um máximo, em 1985. Em 1986 verifica-se uma apreciação do câmbio real, em relação a 1985. Nos dois anos seguintes (1987 e 1988) a taxa de câmbio real continuou no seu movimento de apreciação, conforme indicam os dois indicadores.

\subsection{Política agrícola ${ }^{25}$}

As tentativas de ajuste da economia brasileira à crise da dívida externa levaram não só a mudanças na política macroeconômica, mas, também, tiveram um forte efeito na definição da política agrícola. Dessa forma, na primeira estratégia de ajuste (período 1982/84), a política agrícola foi reorientada para atender o objetivo de reequilíbrio externo, enquanto que, na segunda estratégia de ajuste (período 1986/89), a reorientação da política agrícola teve como finalidade assegurar um rápido crescimento da oferta de alimentos e de matérias-primas.

Os dois principais instrumentos de política agrícola no Brasil são o crédito rural e o Programa de Garantia de Preços Mínimos (PGPM). Os recursos para o crédito rural são provenientes em sua maior parte de fontes oficiais. O Banco do Brasil e outras instituições oficiais são responsáveis por mais de $70 \%$ do total do crédito destinado à agricultura ${ }^{26}$ No PGPM, o governo fixa os preços para aquisição de produtos agrícolas no período da colheita. Os estoques oficiais formados com esse programa são colocados no mercado doméstico no período da entre-safra.

\footnotetext{
${ }^{25}$ Esta seção baseia-se em DALL'ACQUA (1992).
}

${ }^{26}$ Ver DALL'ACQUA (1992). 
Essa alta depedência do crédito rural e do PGPM de fontes oficiais tem importantes implicações sobre a expansão do déficit público e o controle da base monetária. O caráter recessivo da primeira estratégia de ajuste levou a cortes na expansão do crédito rural e a reajustes nos preços mínimos abaixo da inflação ocorrida nesse período. Esta redução da liquidez agrícola e o aumento das taxas de juros elevaram os encargos financeiros pagos pelos agricultores. De modo geral, essa primeira estratégia de ajuste afetou de forma mais intensa a formação de capital no setor agrícola.

Os efeitos de cortes no crédito rural e da menor participação do governo na comercialização agrícola com a redução dos preços reais mínimos de garantia dos principais produtos levaram a uma redução da oferta agrícola. Por outro lado, as políticas monetária e fiscal restritivas adotadas nessa primeira estratégia de estabilização reduziram a absorção interna. Entretanto, a recuperação das cotações internacionais das commodities agrícolas e a maxidesvalorização cambial de fevereiro de 1983 contribuiram para o rápido crescimento dos preços agrícolas relativo aos preços de manufaturados e favoreceram as exportações agrícolas.

Há uma reversão no PGPM e na disponibilidade de crédito ao setor agrícola no período do ajuste heterodoxo. Neste período o governo promoveu uma forte expansão do crédito rural e a política de garantia de preços mínimos teve um caráter expansionista, ou seja, o PGPM foi utilizado deliberadamente para estimular a produção tanto das culturas de exportação quanto das culturas de mercado interno. A prefixação da taxa de juros do crédito rural (durante o Plano Cruzado) resultou em fortes subsídios ao setor agrícola com a rápida aceleração da inflação devido ao descongelamento de preços.

A expansão do crédito e a transferência de grande parte desse crédito na forma de subsídios aos produtores rurais pressionaram a base monetária e o déficit público. Da mesma forma, o aumento da participação do governo na comercialização agrícola pressionou o déficit público. Durante o Plano Cruzado, o governo subsidiou a venda de seus estoques para assegurar o êxito do congelamento de preços. Essa política 
expansionista junto com a recuperação dos preços internacionais de commodities agrícolas e o aumento da absorção interna tiveram um efeito favorável sobre o setor agrícola na segunda metade dos anos oitenta. 


\section{INTERDEPENDÊNCIA ENTRE AGRICULTURA E MERCADO FINANCEIRO: UM MODELO TEÓRICO ${ }^{1}$}

\subsection{Introdução}

Neste capítulo, desenvolve-se um modelo teórico que permite investigar os efeitos de políticas monetárias e cambiais sobre o setor agrícola, no curto prazo. Neste modelo, focalizam-se os efeitos de deslocamentos do equilíbrio num determinado momento do tempo, ignorando-se os aspectos dinâmicos associados aos modelos de longo prazo. Nos experimentos de estática comparativa com o modelo, consideram-se situações como operações de mercado aberto (open market) com títulos domésticos e mudanças exógenas na taxa de câmbio.

O modelo proposto é do tipo equilíbrio de portfolio. Considera-se uma pequena economia aberta que mantém fixa sua taxa de câmbio. As transações desta economia com o resto do mundo envolvem bens e ativos. Supõe-se que esta economia (doravante chamada economia doméstica) experimenta um processo inflacionário, sendo que, no resto do mundo, os preços são estáveis. Em função disso, a taxa de câmbio a ser mantida fixa pode ser: ou a nominal ou a real. Note-se que esta suposição de país pequeno permite que se considerem certas variáveis externas como dadas.

\footnotetext{
1 O desenvolvimento do modelo teórico apresentado neste capitulo baseou-se, principalmente, em BOYER (1975), SAYAD (1979), CHAMBERS (1984) e BARBOSA (1987).
} 
Desagregou-se o mercado de ativos (moeda e títulos) em domésticos e externos e classificaram-se os bens comercializáveis em agrícolas e não-agrícolas (manufaturados). Supõe-se que há arbitragem internacional apenas nas transações com o bem agrícola. No caso do bem manufaturado, supõe-se que o comércio externo do país doméstico é relativamente pequeno, que há excesso de capacidade neste setor ou que existem quotas ou controles cambiais que restringem a arbitragem internacional nesses bens.

No tratamento dos mercados de bens e ativos e das contas do balanço de pagamentos distingue-se entre variáveis estoque e variáveis fluxo. A balança comercial (comércio de bens) do balanço de pagamentos é sempre tratada como um fluxo. Por outro lado, a conta capital é considerada tanto em seu aspecto fluxo quanto estoque. Mais especificamente, o nível de reservas internacionais representa o lado estoque da conta capital. Dessa forma, o modelo foi desagregado em três fluxos e três estoques; no lado do fluxo: bens agrícolas, bens industriais e acumulação líquida de ativos; no lado do estoque: títulos domésticos, títulos externos e moeda.

Distingue-se, também, no modelo, um lado real e um lado financeiro. Estes dois lados interagem entre si. No lado real, ocorre a produção de bens, enquanto no lado financeiro ocorrem as decisões sobre a alocação da riqueza financeira privada. Esta riqueza é composta de moeda, títulos domésticos e ativos externos. No horizonte analítico deste trabalho (curto prazo), supõe-se que a riqueza é predeterminada. Ela é dada pelas acumulações de ativos no passado, pelos preços dos ativos e taxa de câmbio correntes. Ignora-se o efeito de fluxos de poupança sobre a riqueza privada.

Na seção 3.2 apresenta-se formalmente o modelo teórico. Na seção 3.3, analisam-se, por meio de experimentos de estática comparativa, várias políticas de interesse deste estudo. Finalmente, na seção 3.4 , são feitos alguns comentários adicionais. 


\subsection{Modelo}

Dividiu-se a apresentação do modelo em duas partes: na primeira parte, descreve-se o setor financeiro e, na segunda parte, o setor de produção de bens. Em seguida, mostram-se como estes setores se inter-relacionam. Após, então, define-se o conjunto de equações que determinam as variáveis endógenas de interesse.

\subsubsection{Setor financeiro}

O menu de ativos disponiveis aos detentores domésticos de riqueza inclui: obrigações do Banco Central doméstico (moeda) que não proporcionam retorno, ${ }^{2}$ títulos (bonds) domésticos (indexados) que proporcionam um retorno $r$ (taxa nominal de juros doméstica) e títulos externos que proporcionam um retorno $r^{*}$ (taxa nominal de juros externa). Para os propósitos desta análise, $r^{*}$ é exógena. Os detentores de riqueza do resto do mundo não possuem em seus portfolios títulos ou moeda do país doméstico. ${ }^{3}$ Supõe-se que esses ativos são substitutos imperfeitos.

Os mercados de moeda doméstica e títulos externos são relativamente grandes, de forma que os detentores domésticos de riqueza podem ajustar suas quantidades desses ativos sem afetar seus preços, dado qualquer incipiente excesso de oferta ou demanda. Por outro lado, supõe-se que o governo doméstico seja grande o bastante no mercado de títulos domésticos para ser capaz de influenciar a taxa de retorno desse ativo. Num dado momento do tempo, supõe-se que a riqueza privada nominal

\footnotetext{
2 Na verdade, numa economia com taxa de inflação positiva, o retorno da moeda é igual ao negativo da taxa de inflação esperada.

3 Pode-se argumentar que o país doméstico não possui um sistema financeiro suficientemente desenvolvido, que impõe restrições ao capital externo e/ou seu estado inflacionário gera desconfanças em possiveis investidores externos.
} 
esteja dada. A composição dos portfolios dos detentores de riqueza depende da riqueza financeira e das taxas esperadas de retorno dos títulos domésticos e externos.

Neste trabalho, focaliza-se basicamente o país doméstico. Assim, a riqueza financeira privada nominal da economia doméstica é dada por:

$$
W=M+B+E B^{*}
$$

em que

$$
\begin{aligned}
& W=\text { riqueza financeira privada nominal doméstica; } \\
& M=\text { crédito doméstico líquido (em valores nominais) }{ }^{4} \\
& B=\text { estoque nominal de títulos emitidos pelo governo doméstico em }
\end{aligned}
$$
poder do setor privado;

$E=$ taxa nominal de câmbio (preço da divisa externa em unidades da moeda doméstica); e

$$
B^{*}=\text { estoque nominal de títulos externos (avaliado em moeda externa) }
$$
em poder dos detentores de riqueza da economia doméstica.

Num modelo de portfolio, requer-se que, no equilíbrio, as demandas por estoques de ativos financeiros igualem aos estoques disponiveis destes ativos (ofertas). As condições de equilíbrio de mercado dos ativos moeda, títulos domésticos e títulos externos são dadas por:

$$
\begin{aligned}
& m(r, W)=M_{s} \\
& b(r, W)=B \\
& b^{*}(r, W)=E B^{*}
\end{aligned}
$$

em que

$$
M_{s}=\text { oferta monetária nominal doméstica. }
$$

\footnotetext{
4 Está-se denominando crédito doméstico líquido o crédito doméstico menos o passivo não monetário. Ver balancete consolidado das autoridades monetárias no capítulo 2 .
} 
Todo aumento de quaisquer dos ativos considerados é demandado. As variáveis endógenas devem-se ajustar para induair os detentores de riqueza a absorverem as variações nos estoques de quaisquer dos ativos considerados. Note-se também que, dada a restrição de riqueza, apenas duas das três condições de equilíbrio acima são suficientes para capturar toda a informação necessánia sobre os três mercados. Se, por exemplo, os excessos de demanda por moeda e títulos domésticos forem iguais a zero, segue-se que o excesso de demanda por títulos externos é também igual a zero.

A partir das condições de equilibrio acima, podem-se definir as seguintes derivadas parciais:

$$
\begin{array}{lll}
m_{r}=\frac{\partial m}{\partial r} & \text { e } & m_{w}=\frac{\partial m}{\partial W} \\
b_{r}=\frac{\partial b}{\partial r} & \text { e } & b_{w}=\frac{\partial b}{\partial W} \\
b_{r}^{*}=\frac{\partial^{*}}{\partial r} & \text { e } & b_{w}^{*}=\frac{\partial b^{*}}{\partial W}
\end{array}
$$

Supõe-se que as derivadas parciais das demandas por estoques em relação às próprias taxas de retorno dos ativos $\left(b_{r}\right)$ e riqueza nominal $\left(m_{w}, b_{k}\right.$ e $\left.b_{w}^{*}\right)$ são positivas, enquanto as derivadas parciais cruzadas $\left(-m_{r}\right.$ e $\left.-b_{r}^{*}\right)$ são negativas. Dado o conjunto de ativos, a soma das respostas das demandas por estes ativos a uma variação na taxa de retorno $r$ é zero. Por outro lado, o somatório das variações nas demandas por ativos proporcionadas por uma variação na riqueza nominal é igual a um. ${ }^{5}$ Esses últimos resultados estão sumariados nas equações (13) e (14) abaixo:

$$
\begin{aligned}
& -m_{r}+b_{r}-b_{r}^{*}=0 \\
& m_{k}+b_{k}+b_{w}^{*}=1
\end{aligned}
$$

A oferta monetária doméstica é igual à soma do crédito doméstico líquido criado pelo Banco Central doméstico $(M)$ e dos ativos externos em poder deste banco

${ }^{5}$ Ver. por exemplo. TOBIN (1969) para uma argumentação a este respeito. 
vezes o multiplicador monetário. ${ }^{6} \mathrm{O}$ componente externo da oferta monetária doméstica depende da acumulação líquida de ativos externos. Dessa forma, supondo-se que o multiplicador monetário é igual a um, ${ }^{7}$ tem-se como oferta monetária doméstica:

$$
M_{s}=M+E B^{*}
$$

Numa economia inflacionária, os detentores de riqueza retêm cada vez menos moeda e a utilizam apenas quando estritamente necessário (nas transações), já que esse ativo não proporciona nenhum retorno e uma taxa de inflação positiva deprecia seu poder de compra. No caso dos títulos domésticos, quanto mais alta a taxa de inflação, os detentores de riqueza, para reterem estes ativos, exigirão um prêmio maior para compensar o risco de depreciação de seus patrimônios ou, alternativamente, requererão prazos de maturidade menores ou condicionarão suas aquisições a cláusulas de indexação (VIAL, 1989). Para os propósitos deste trabalho, os títulos domésticos são indexados.

O governo assume os riscos da inflação futura quando emite títulos indexados. Segundo VIAL (1989), substituir títulos não-indexados por títulos indexados leva a uma redução nas taxas reais de juros requeridas pelos detentores de riqueza para manterem em seus portfolios títulos do governo. Com isso, há uma queda no custo real da dívida pública e, conseqüentemente, uma redução de sua carga. ${ }^{8}$ Neste trabalho, abstrai-se de questões relacionadas à restrição orçamentária do governo, ou seja, se ela obedece ou não sua restrição intertemporal, mesmo porque a análise aqui é de curto prazo. Entretanto, são de interesse os efeitos sobre as variáveis endógenas de operações de mercado aberto realizadas pelo Banco Central com esses títulos.

\footnotetext{
${ }^{6}$ O Banco Central doméstico, nesse modelo, detém o monopólio de compra e venda de divisas. O exportador, por exemplo, troca suas divisas por moeda doméstica junto ao Banco Central; o inverso ocorre com o importador (ou na liquidação de um emprestimo externo) que deve adquirir as divisas necessárias junto a esse banco.

Isto equivale a dizer que a oferta de moeda é idêntica à base monetária. Trata-se de uma simplificação que é também utilizada, por exemplo, em KOURI \& PORTER (1974).

${ }^{8}$ Ver também TOBIN (1971) para uma das primeiras abordagens sobre essas questôes.
} 
A indexação de preços numa economia com taxa de inflação positiva pode ocorrer via taxa de câmbio. Quando o regime é de taxa de câmbio fixa, o Banco Central, que detém o monopólio de compra e venda de divisas externas, pode fixar ou a taxa nominal ou a taxa real de câmbio. Políticas que buscam manter constante a taxa real de câmbio preservam a paridade do poder de compra entre as moedas. Definindo-se a taxa de câmbio como o preço da divisa externa em termos da moeda doméstica, tem-se:

$$
E=E_{0}\left(\frac{p}{p^{*}}\right)^{\gamma}
$$

em que

$$
p=\text { índice geral de preços doméstico (combinação convexa dos índices }
$$
de preços agrícola e industrial);

$p^{*}=$ indice geral de preços externo (combinação convexa dos índices de preços agrícola e industrial externos).

O parâmetro de indexação cambial $\gamma$ pode assumir valores entre zero e 1 (um). Quando $\gamma$ for igual a 1, a taxa de câmbio real é constante. No caso oposto, ou seja, quando $\gamma$ for igual a zero, a taxa de câmbio nominal é que é constante. $E_{0}$ é a taxa de câmbio que prevaleceria na ausência de variações não antecipadas nos índices de preços domésticos e externos. $\mathrm{Na}$ seção seguinte, que trata da produção de bens, discute-se uma outra forma de indexação de preços.

\subsubsection{Setor de produção de bens}

Dividiu-se o setor produtivo da economia doméstica em dois subsetores: um que produz bens agrícolas e outro que produz bens manufaturados (industriais). Nesta seção, está-se interessado, basicamente, no processo de formação dos preços 
nominais nestes dois subsetores. Mais adiante, neste capítulo, a análise será estendida para se verificar em que extensão o setor financeiro afeta esses subsetores e vice-versa.

Uma característica da agricultura, que a distingue de outros setores da economia e que vem sendo extensivamente explorada na literatura, é sua flexibilidade de preços, ou seja, os preços agrícolas flutuam livremente ao sabor das forças competitivas de mercado de ofertas e demandas. ${ }^{9}$ Os argumentos para justificar esta estilização são: a existência de um grande número de produtores que ofertam um produto homogêneo no mercado, o fato de muitas commodities agrícolas serem comercializadas em bolsas de mercadorias e, no caso das economias abertas, o comércio externo agrícola que reforça esta característica. ${ }^{10}$ Em função disso, os agricultores são incapazes de influenciar os preços de seus bens (agrícolas) quando de sua comercialização.

Por outro lado, o setor industrial é tido como um setor cujos preços são rígidos no curto prazo. SAYAD (1979) caracteriza este setor como sendo de concentração elevada, cuja produção está nas mãos de alguns poucos produtores, sendo resultado da existência de economias de escala, produtos diferenciados e barreiras financeiras à entrada de novos produtores. Neste setor, os produtores têm o poder de fixar seus preços e o fazem acrescentando uma margem (markup) aos seus custos variáveis de produção. Esta margem é estabelecida de forma a evitar rivalidade entre os diversos ofertantes ou a entrada de novos produtores que poderiam comprometer os investimentos industriais.

SAYAD (1979) afirma que os ofertantes do setor industrial, por exemplo, não baixam os preços nominais de seus bens quando há uma redução na demanda. Sua argumentação é que isto faria com que os ofertantes rivais também reduzissem seus preços nominais, o que anularia qualquer efeito sobre as vendas e diminuiria as margens de lucros. Este autor classifica a agricultura como um setor concorrencial (trabalha com pleno emprego), enquanto o setor industrial é classificado como um oligopólio (há

\footnotetext{
9 No setor financeiro, supōe-se também que os preços flutuam livremente em resposta às interaçôes competitivas de mercado de ofertas e demandas.

1. Ver SAYAD (1979).
} 
excesso de capacidade). Dessa forma, a agricultura é tida como uma economia clássica, enquanto a indústria é tida como uma economia keynesiana. ${ }^{11}$

Uma outra explicação para a inflexibilidade para baixo dos preços nominais industriais, no curto prazo, é que, nesse setor, trabalha-se, em geral, com contratos de longo prazo e têm-se custos de ajustamento às variações nas condições de mercado. ${ }^{12}$ Diversos autores ${ }^{13}$ costumam considerar os preços dos bens agrícolas como sendo flex-prices e os preços dos bens industriais como sendo fix-prices. ${ }^{14}$ Nesta concepção, não se quer dizer que os preços industriais nunca mudam, apenas que não são determinados pela interação das curvas de ofertas e demandas, no curto prazo, como é no caso dos preços agrícolas. Os preços industriais, eventualmente, podem-se ajustar às pressões de ofertas e demandas, no longo prazo.

Em diversos modelos teóricos que visam investigar os efeitos de políticas monetárias sobre o setor agrícola, costuma-se utilizar a divisão: flex-price para o preço agrícola e fix-price para o preço industrial. ${ }^{15}$ Assim, na manipulação algébrica desses modelos, que normalmente são análises de curto prazo, o preço industrial é mantido fixo. Sob estas condições, qualquer variação no estoque nominal de moeda é também uma variação no estoque real de moeda (isto decorre simplesmente da existência de alguns preços rigidos na economia). Dessa maneira, as políticas monetárias tendem a afetar mais intensamente o setor agrícola. Este tipo de concepção parece adequado para economias relativamente estáveis. Entretanto, para economias que experimentam processos inflacionários, os reajustes de preços tendem a ser feitos em períodos de tempo cada vez mais curtos, mesmo no caso dos preços nominais industriais.

Uma forma que parece mais apropriada para se trabalhar com preço relativo agricultura-indústria numa economia inflacionária seria considerar mecanismos

\footnotetext{
11 KALECKI (1978) trata as estruturas de mercado aqui discutidas de uma forma bastante semelhante.

${ }^{12}$ Ver, por exemplo, STAMOULIS \& RAUSSER (1988).

13 Ver, por exemplo, CHAMBERS (1984).

${ }^{14}$ Esta classificação de preços flex x fix é devida a HICKS (1974).

15 Ver, por exemplo. CHAMBERS (1984).
} 
de indexação no modelo. MODIANO (1985) e BARBOSA (1987), por exemplo, propõem modelos de cunho estruturalista que consideram mecanismos de indexação na taxa de câmbio e na formação dos preços industriais. Nestes modelos, os preços industriais são determinados pelos custos variáveis de produção e o nível de produção, pela demanda, enquanto, no caso do setor agrícola, os preços e níveis de produção são determinados de forma concorrencial pela interação das curvas de ofertas e demandas.

No modelo teórico desenvolvido neste capítulo, consideram-se explicitamente mecanismos de indexação. Dividiu-se o setor produtivo da economia doméstica em dois subsetores: um agrícola e outro industrial. No setor agrícola, trabalha-se sob condições de concorrência perfeita com pleno emprego dos fatores, enquanto no setor industrial tem-se uma estrutura de mercado oligopolística e há excesso de capacidade. Portanto, como em SAYAD (1979), modela-se o setor agrícola como uma economia clássica e o setor industrial como uma economia keynesiana.

Como já referido, supõe-se que há arbitragem internacional apenas nas transações com o bem agrícola. Os bens industriais podem ser consumidos, reinvestidos ou eventualmente exportados (não há estocagem de bens industriais). As exportações de bens industriais domésticos são relativamente pequenas e a existência de controles cambiais ou quotas impedem a arbitragem internacional nestes bens. Supõe-se também que as importações são realizadas apenas pelo setor industrial e constituem-se de matérias-primas e bens intermediários. Os bens agrícolas, além de exportados, são consumidos como alimento pela população e podem também ser utilizados como matéria-prima pelo setor industrial.

No curto prazo, que constitui o horizonte analítico deste trabalho, supõese que a estrutura da economia doméstica está dada. Isso quer dizer que, no curto prazo, essa economia possui algumas características que não podem ser alteradas ou cujas alterações não podem ser realizadas por meio de uma simples medida de política econômica. Como em SAYAD (1979), supõe-se que essa imutabilidade está associada ou à tecnologia disponível ou à própria distribuição de renda. 
A oferta do bem agrícola doméstico é descrita pela função: ${ }^{16}$

$$
X_{A}=X_{A}\left(p_{A}\right)
$$

em que

$$
X_{A}=\text { oferta do bem agrícola doméstico; e }
$$

$p_{A}=$ preço do bem agrícola, em moeda doméstica;

A derivada desta função de oferta em relação ao seu argumento é positiva.

Uma outra característica inerente ao setor agrícola é que a produção, em geral, concentra-se num determinado periodo do tempo. Por outro lado, nem toda a produção colhida é consumida no mesmo período, sendo necessária a estocagem de bens agrícolas para consumo num período posterior. Supõe-se que o país doméstico estoca os bens agrícolas. Consideraram-se como um dos principais componentes dos custos de estocagem os encargos de juros. ${ }^{17}$ As demandas por bens agrícolas para consumo e estocagem são resumidas pela seguinte função:

$$
D_{A}=D_{A}\left(p_{A}, r\right)
$$

em que

$$
D_{A}=\text { demanda por bem agrícola doméstico. }
$$

As derivadas parciais desta função em relação aos seus argumentos são negativas.

Tanto os bens agrícolas quanto os bens industriais foram considerados bens comercializáveis, com a diferença de que há arbitragem internacional apenas no caso dos bens agrícolas. Os preços destes bens, portanto, ajustam-se mais rapidamente

\footnotetext{
${ }^{16}$ Essa especificação é a mesma utilizada em SAYAD (1979). A única diferença é que este autor subdividiu o setor agricola em dois subsetores: um que produz bens que se destinam exclusivamente ao mercado doméstico e outro que produz bens exportáveis. Esta especificação reflete a pouca mobilidade de fatores de produção entre os setores agrícola e industrial.

1. Ver CHAMBERS (1984).
} 
em relação aos preços dos bens industriais. Os excessos de ofertas ou demandas desses bens (agrícolas e industriais) não são necessariamente iguais a zero e devem ser satisfeitos através do setor externo. No caso do bem agrícola, a condição de equilíbrio requer que o somatório dos excessos de oferta deste bem no país doméstico e no resto do mundo seja igual a zero, ou seja:

$$
\left(X_{A}-D_{A}\right)+\left(X_{A}^{*}-D_{A}^{*}\right)=0
$$

em que o asterisco $\left(^{*}\right)$ é utilizado para denotar o resto do mundo.

A especificação da condição de equilíbrio (19) é semelhante à proposta por CHAMBERS (1984), no caso da economia norte-americana. A agricultura norteamericana, evidentemente, é muito mais importante em nível mundial do que a brasileira. Entretanto, deve-se ressaltar que o Brasil é um importante exportador de commodities mundiais como o café, cacau, farelo de soja e suco de laranja. Note-se que a condição (19) não impõe, necessariamente, que as exportações do país doméstico influenciem de forma significativa os preços mundiais de bens agrícolas.

Com a condição (19) quer-se destacar que tanto os aspectos internos da economia doméstica quanto os aspectos externos são importantes na formação dos preços agrícolas. Note-se que se está trabalhando em nível agregado, sendo que alguns bens agrícolas domésticos são menos susceptíveis ao que ocorre no mercado externo. ${ }^{18}$ No caso específico do Brasil, destaca-se, também, o aumento da importância do mercado interno para os bens agrícolas durante a década de $80 .^{19}$

Em condições de livre comércio, o preço do bem agrícola doméstico é igual ao preço externo deste bem multiplicado pela taxa de câmbio:

$$
p_{A}=p_{A}^{*} E
$$

\footnotetext{
${ }^{18}$ Evitou-se utilizar, na formulação do modelo teórico deste capítulo, a divisão entre produtos agrícolas exportáveis e de consumo interno. Autores como, por exemplo. MANOEL \& MENDONÇA DE BARROS (1987) admitem que esta divisão está perdendo sua importância no atual contexto do desenvolvimento da agricultura brasileira.

19 Ver, por exemplo, DIAS (1989).
} 
Como já enfatizado, os niveis de produção e preço dos bens agrícolas são determinados pela interação concorrencial das curvas de ofertas e demandas. No caso do setor industrial, supõe-se que o nivel de produção é determinado pela demanda e que o nível de preço é estabelecido a partir dos custos de produção. Estes custos incluem bens agrícolas, matérias-primas e bens intermediários importados. Especificamente, o preço industrial é fixado por uma regra de markup, ou seja, aos custos variáveis unitários acrescenta-se uma margem constante de lucro. Formalmente, tem-se:

$$
p_{I}=\pi_{0}\left(p_{A}\right)^{\theta \pi_{1}}\left(E p^{*}\right)^{\left(1-\pi_{1}\right)}
$$

em que

$$
0 \leq \theta \leq 1, \text { e } 0<\pi_{1}<1
$$

$p_{I}=$ preço do bem industrial doméstico;

$\pi_{0}=$ margem de lucro constante por unidade do bem industrial; e

$\pi_{1}=$ parcela do custo variável atribuída aos insumos agrícolas.

Por suposição, o bem agrícola afeta os custos industriais como matériaprima e/ou via custos salariais. Neste último caso, estar-se-ia enfatizando o caráter de bem de salário apresentado pelos bens agrícolas. Esse procedimento é utilizado em BARROS (1990). O parâmetro $\theta$ é tomado como uma medida do grau por meio do qual as variações nos preços agrícolas são transmitidas aos custos industriais. Se, por exemplo, os salários não forem indexados aos preços agrícolas, então $\theta=0$. Por outro lado, se os salários forem indexados de forma perfeita aos preços agrícolas, então $\theta=1$.

$O$ índice geral de preços da economia doméstica é uma combinação convexa dos indices de preços agrícola e industrial:

$$
p=\alpha_{1} p_{A}+\alpha_{2} p_{1}, \quad \alpha_{1}+\alpha_{2}=1
$$

O valor bruto da produção doméstica é dado por:

$$
Y=p_{A} X_{A}+p_{I} X_{1}
$$


em que

$$
\begin{aligned}
& Y=\text { valor bruto da produção doméstica; e } \\
& X_{I}=\text { produção industrial doméstica. }
\end{aligned}
$$

Numa economia aberta, o valor bruto da produção doméstica nem sempre é igual ao dispêndio agregado. $\mathrm{O}$ excesso de demanda por fluxo de ativos é igual à diferença entre o valor bruto da produção doméstica e o dispêndio agregado. Supondose que o país doméstico tenha que transferir ao resto do mundo um determinado valor constante $T E$, em cada período, a título de pagamento do serviço da dívida externa, tem-se como diferença entre o valor da produção doméstica e $T E\left(Y_{L}\right)$, ou seja:

$$
Y_{L}=Y-T E
$$

O dispêndio $(Q)$ é igual ao valor monetário da demanda por bens:

$$
Q=p_{A} D_{A}+p_{I} D_{I}+E p^{*} M_{I}
$$

em que

$M_{1}=$ quantidade importada pelo setor industrial doméstico de matériasprimas e bens intermediários.

Uma vez que se tenham definido essas magnitudes, torna-se fácil relacionar os excessos de demanda nos diversos mercados uns com os outros. Essa interdependência pode ser formalizada da seguinte forma: qualquer desequilíbrio no saldo em transações correntes do balanço de pagamentos é coberto por fluxos de ativos externos. ${ }^{20}$ Quando se subtrai $Y_{L}$ do dispêndio agregado, obtêm-se:

$$
Y_{L}-Q=d B^{*}=p_{A}\left(X_{A}-D_{A}\right)+N X_{I}-T E
$$

em que

$$
N X_{1}\left[=p_{I}\left(X_{I}-D_{l}\right)-E p^{*} M_{I}\right]=\text { valor das exportações líquidas do setor }
$$
industrial, em moeda doméstica; e 
$d B^{*}=$ acumulação líquida de ativos externos.

O lado direito da expressão (25) é o valor monetário do superávit da balança comercial mais os pagamentos relativos à conta do serviço da dívida externa, cujo resultado dá o saldo do balanço de pagamentos em conta-corrente mais amortizações da dívida externa. Esta é uma condição de equilíbrio quando todas as magnitudes são interpretadas no sentido ex ante; ex post é apenas uma identidade contábil.

Neste ponto da exposição do modelo, já se pode definir o conjunto de equações que determinam as variáveis endógenas de interesse. O modelo completo consiste de quatro variáveis endógenas: o preço do bem agrícola, o preço do bem industrial, a taxa nominal de juros doméstica e a componente externa da oferta monetária doméstica; e quatro condições de equilibrio: os mercados de moeda e títulos domésticos, o mercado do bem agrícola e a equação que determina o preço industrial, isto é:

$$
\begin{aligned}
& m(r, W)=M_{s} \\
& b(r, W)=B \\
& \left(X_{A}-D_{A}\right)+\left(X_{A}^{*}-D_{A}^{*}\right)=0 \\
& p_{1}=\pi_{0}\left(p_{A}\right)^{\theta \pi_{1}}\left(E p^{*}\right)^{\left(1-\pi_{1}\right)}
\end{aligned}
$$

A partir desse sistema de equações, podem-se analisar os efeitos de mudanças em diversas variáveis exógenas sobre as variáveis endógenas do modelo. Entretanto, como o interesse deste estudo recai sobre os efeitos de políticas monetárias e cambiais sobre o preço relativo agricultura-indústria, consideraram-se como variáveis exógenas relevantes, para efeito dos experimentos de estática comparativa, apenas o crédito doméstico líquido criado pelo Banco Central doméstico $(M)$, os títulos domésticos e a taxa de câmbio. 
As condições de equilibrio (26), (27) e (28) e a equação de formação do preço industrial (29) podem ser diferenciadas totalmente nas proximidades do equilíbrio, para gerar o seguinte sistema de equações:

$$
\begin{aligned}
& -m_{r} d r+m_{x} d W=d M_{s} \\
& b_{r} d r+b_{x} d W=d B \\
& {\left[x_{a} d p_{A}-\left(-a_{a} d p_{A}-a_{r} d r\right)\right]+} \\
& +\left[x_{a}^{*} d p_{A}^{*}-\left(-a_{a}^{*} d p_{A}^{*}-a_{r}^{*} d r^{*}\right)\right]=0 \\
& \frac{1}{p_{I}} d p_{I}=\frac{\theta \pi_{1}}{p_{A}} d p_{A}+\frac{\left(1-\pi_{1}\right)}{E} d E
\end{aligned}
$$

em que os coeficientes $m_{i}, b_{i}, x_{a}, a_{a}$ e $a_{r}(i=r, w)$ são positivos e representam derivadas parciais. ${ }^{21}$ Para completar a diferencial total das equações acima, deve-se tomar ainda o diferencial de $d M_{s}, d E$ e $d W$, cujas definições foram dadas, respectivamente, pelas expressões (15), (16) e (9). Lembrar ainda que se têm diferentes opções de indexação da economia doméstica.

Dependendo da forma de indexação que se considere que vigore na economia doméstica, pode-se gerar quatro outros sistemas. Essas quatro possibilidades são: a) ausência completa de indexação $(\gamma=0, \theta=0)$; b) indexação apenas na fixação do preço do bem industrial $(\gamma=0, \theta=1)$; $)$ indexação apenas na taxa de câmbio $(\gamma=1$, $\theta=0)$; e d) indexação perfeita da economia $(\gamma=1, \theta=1)$. Este último caso descreveria melhor uma situação de longo prazo, enquanto a ausência de indexação descreveria uma situação de curtíssimo prazo.

${ }^{21}$ Lembrar que o asterisco $(*)$ é utilizado para indicar o setor externo (resto do mundo). Na diferenciação total desse sistema de equações, considerou-se que $p^{*}=1$, de forma que $\ln p^{*}=0$. Estáse admitindo que tanto os pesos quanto o preço agrícola externo podem variar, para que esta normalização seja satisfeita. 
Por exemplo, completando o diferencial total do sistema dado pelas equações de (30) a (33), na vizinhança do equilíbrio, e considerando-se que $\gamma=0$ e $\theta=0$, ou seja, que não há indexação na economia doméstica, obtém-se o seguinte sistema de equações em notação matricial:

$$
\begin{aligned}
& \left.\left[\begin{array}{cccc}
\left(m_{w}-1\right) E_{\bullet} & -m_{r} & 0 & 0 \\
b_{w} E_{\bullet} & b_{r} & 0 & 0 \\
0 & a_{r} & z+z^{*} / E_{0} & 0 \\
0 & 0 & 0 & 1 / p_{I}
\end{array}\right] \begin{array}{c}
d B^{*} \\
d r \\
d p_{A} \\
d p_{I}
\end{array}\right]= \\
& =\left[\begin{array}{c}
1-m_{w^{*}} \\
-b_{w} \\
0 \\
0
\end{array}\right] d M+\left[\begin{array}{c}
-m_{w^{*}} \\
1-b_{w} \\
0 \\
0
\end{array}\right] d B+\left[\begin{array}{c}
\left(1-m_{w^{*}}\right) B^{*} \\
-b_{w} B^{*} \\
z^{*} p_{A} / E_{0}^{2} \\
\left(1-\pi_{1}\right) / E_{0}
\end{array}\right] d E_{0}
\end{aligned}
$$

em que

$$
\begin{aligned}
& z=x_{a}+a_{a} ; z^{*}=x_{a}^{*}+a_{a}^{*} ; \text { e } \\
& d B^{*}=\text { mudança na oferta monetária doméstica através do setor externo, }
\end{aligned}
$$
isto é, aumento no nível de reservas internacionais sem esterilização.

Uma vez definida a forma de indexação relevante e as variáveis exógenas de interesse, pode-se proceder à análise de estática comparativa. Nesta análise, que é desenvolvida na próxima seção, procura-se identificar os efeitos de políticas monetárias e cambiais sobre o preço relativo agricultura-indústria. Consideram-se como políticas monetárias as operações de mercado aberto com títulos domésticos e como políticas cambiais as desvalorizações da taxa de câmbio (choques cambiais). 


\subsection{Experimentos de estática comparativa}

A análise de estática comparativa desenvolvida nesta seção foi dividida em duas partes: na primeira parte, analisam-se os efeitos de operações de mercado aberto com títulos domésticos sobre o preço relativo agricultura-indústria; na segunda parte, são considerados os efeitos de choques cambiais sobre esse mesmo preço.

\subsubsection{Operações de mercado aberto}

Nesta seção consideram-se os efeitos de operações de mercado aberto conduzidas pelo Banco Central doméstico sobre o preço relativo agricultura-indústria. Uma operação de mercado aberto consiste numa troca de ativos entre o Banco Central e o setor privado, ou seja, o Banco Central compra ou vende suas obrigações (moeda) em troca de títulos domésticos. Por exemplo, numa operação com títulos domésticos expansionista, o Banco Central vende suas próprias obrigações em troca desses títulos. Neste caso, mais moeda passa a circular na economia.

Convém mencionar que se está considerando que não são feitas esterilizações para neutralizar total ou parcialmente as mudanças nas fontes monetárias externas; a oferta de moeda doméstica é, portanto, parcialmente endógena. Para iniciar os exercícios de estática comparativa, considere-se o sistema de equações em notação matricial obtido na seção anterior. Definindo as matrizes e vetores, têm-se:

$$
A_{1}=\left[\begin{array}{cccc}
\left(m_{w}-1\right) E_{0} & -m_{r} & 0 & 0 \\
b_{u^{\prime}} E_{0} & b_{r} & 0 & 0 \\
0 & a_{r} & z+z^{*} / E_{0} & 0 \\
0 & 0 & 0 & 1 / p_{l}
\end{array}\right]
$$




$$
M_{1}=\left[\begin{array}{c}
1-m_{w} \\
-b_{w} \\
0 \\
0
\end{array}\right], \quad B_{1}=\left[\begin{array}{c}
-m_{w} \\
1-b_{w} \\
0 \\
0
\end{array}\right] \text { e } C_{1}=\left[\begin{array}{c}
\left(1-m_{w}\right) B^{*} \\
-b_{w} B^{*} \\
z^{*} p_{A} / E_{0}^{2} \\
\left(1-\pi_{1}\right) / E_{0}
\end{array}\right]
$$

Numa operação de mercado aberto com títulos domésticos tanto o mercado monetário quanto o mercado de títulos domésticos são afetados (ver sistema de equações 34). No caso de uma política expansionista, tem-se no lado direito desse sistema de equações que: $d B=-d M$ e $d E_{0}=0 . d M$ é o excesso de oferta de moeda criada pelo Banco Central doméstico (mudança no crédito doméstico líquido). Os efeitos de desvalorizações cambiais são avaliados considerando-se: $d B=0, d M=0$ e $d E_{0} \neq 0$, efeitos estes que não afetam a oferta monetária doméstica, dada a natureza de equilíbrio geral do modelo que está sendo manipulado algebricamente.

Os efeitos de uma política monetária conduzida com títulos domésticos são obtidos algebricamente a partir do produto da inversa da matriz $A_{1}$ com o vetor resultante da subtração dos vetores $M_{1}$ e $B_{1},\left(M_{1}-B_{1}\right)$, ou seja:

$$
\left[\begin{array}{c}
d B^{*} \\
d r \\
d p_{A} \\
d p_{I}
\end{array}\right]=\left[\begin{array}{c}
\frac{-b_{r}+m_{r}}{E_{0}\left(-b_{r} m_{w^{\prime}}+b_{r}-b_{w} m_{r}\right)} \\
\frac{b_{w}+m_{w^{\prime}}-1}{-b_{r} m_{w^{*}}+b_{r}-b_{w} m_{r}} \\
\frac{E_{0} a_{r}\left(b_{w}+m_{w}-1\right)}{\left(z E_{0}+z^{*}\right)\left(b_{r} m_{w}-b_{r}+b_{w} m_{r}\right.} \\
0
\end{array}\right] d M
$$


Essa política produz um efeito ambíguo sobre o nível de reservas: o sinal depende, basicamente, das magnitudes das derivadas parciais $b_{r}$ e $m_{r} ;$ se $b_{r}>m_{r}$ há perda de reservas. Os outros efeitos são: decréscimo na taxa nominal de juros e aumento no preço agrícola. O preço industrial permanece inalterado. Note-se que esse tipo de política favorece o setor agrícola relativo ao setor industrial, ou seja, o termo doméstico de troca melhora em favar da agricultura.

\subsubsection{Desvalorizações cambiais}

Considere-se, agora, os efeitos sobre as variáveis endógenas de interesse de uma desvalorização cambial. Estes efeitos podem ser obtidos a partir do produto da inversa da matriz $A_{1}$ com o vetor $C_{1}$, ou seja:

$$
\left[\begin{array}{c}
d B^{*} \\
d r \\
d p_{A} \\
d p_{1}
\end{array}\right]=\left(A_{1}^{-1} C_{1}\right) d E_{0}=\left[\begin{array}{c}
\frac{-B^{*}}{E_{0}} \\
0 \\
\frac{p_{A} z^{*}}{E_{0}\left(z E_{0}+z^{*}\right)} \\
\frac{p_{1}\left(1-\pi_{1}\right)}{E_{0}}
\end{array}\right] d E_{0}
$$

Esse resultado mostra que uma desvalorização cambial leva à perda de reservas $^{22}$ e ao aumento dos preços agrícola e industrial. Esse tipo de política não altera a taxa nominal de juros doméstica. O efeito sobre as relações de troca agricultura-

22 Note-se que não se está permitindo que a oferta monetána doméstica varie. Dada a natureza de equilíbrio geral do modelo, se algumas variáveis endógenas aumentam de valores as outras variáveis endógenas tem que ter seus valores diminuidos. Ver mais explicações nos parágrafos seguintes. 
indústria depende de qual dos preços sofreu maior aumento (se o preço agrícola ou o preço industrial). Dividindo-se $\left(d p_{A} / d E_{0}\right)$ por $\left(d p_{I} / d E_{0}\right)$, obtém-se: $:^{23}$

$$
\frac{d p_{A}}{d p_{I}}=\frac{z^{*}}{\left(z E_{0}+z^{*}\right)\left(1-\pi_{1}\right)}>0
$$

Não se pode dizer a priori qual dos setores (agrícola ou industrial) é mais favorecido por uma desvalorização cambial, pois o resultado dado pela expressão (37) é ambíguo e depende basicamente da magnitude de $\pi_{1}$. Esse parâmetro mede a parcela do custo variável industrial atribuída aos insumos agricolas. Quanto maior a participação desses insumos nos custos variáveis industriais, maior as chances de uma desvalorização cambial favorecer o setor agrícola.

Deve ser ressaltado que esses efeitos da desvalorização cambial são parciais, ou seja, não se está permitindo que a oferta monetária doméstica varie $\left(d M_{s}=0\right)$. É razoável supor, entretanto, que uma desvalorização cambial leve ao aumento das exportações domésticas e, com isso, eleve o nível das reservas. Desde que não haja esterilizações, o aumento do nivel de reservas internacionais aumentará a oferta monetária doméstica que, por sua vez, levará a uma redução da taxa nominal de juros doméstica, favorecendo, dessa forma, a agricultura. Uma vez que se está supondo que não há arbitragem internacional no caso dos bens industriais, é razoável também supor que os preços destes bens se ajustarão mais lentamente em relação aos preços agrícolas no caso de uma desvalorização cambial.

Tentou-se fazer os cálculos permitindo mudanças na oferta de moeda; entretanto, obteve-se uma expressão de tal forma complexa que não foi possivel avaliar seus efeitos sobre o preço relativo agricultura-indústria. Uma outra tentativa feita foi considerar uma desvalorização cambial associada com uma política monetária contracionista, visando simular o que ocorreu na economia brasileira na primeira metade

\footnotetext{
${ }^{23}$ Considerou-se que. imediatamente antes de qualquer choque, $p_{s=1} / p_{1}=1$.
} 
da década de 80. Como no caso anterior, obteve-se também uma expressão complexa de pouca utilidade analítica.

Esses resultados dos efeitos das políticas monetárias e cambiais sobre as variáveis endógenas de interesse foram obtidos considerando-se que não há indexação na economia. Na Tabela 7, mostram-se os resultados obtidos dos efeitos de operações de mercado aberto com títulos domésticos e de desvalorizações cambiais sobre o preço relativo agricultura-indústria, quando se consideram diversas formas de indexação. Todos os cálculos referentes a estes resultados estão no Apêndice 1 deste trabalho. ${ }^{24}$

Tabela 7 - Efeitos de operações de mercado aberto com títulos domésticos e de desvalorizações cambiais sobre o preço relativo agricultura-indústria

\begin{tabular}{l|c|c}
\hline Forma de indexação & $\begin{array}{c}\text { Operação de mercado aberto } \\
\left(d p_{A} / d p_{I}\right)\end{array}$ & $\begin{array}{c}\text { Desvalorização cambial } \\
\left(d p_{A} / d p_{I}\right)\end{array}$ \\
\hline$\gamma=0, \theta=0$ & $*$ & $?$ \\
$\gamma=0, \theta=1$ & $>1$ & $<1$ \\
$\gamma=1, \theta=0$ & $?$ & $?$ \\
$\gamma=1, \theta=1$ & $=1$ & $<1$ \\
\hline
\end{tabular}

Fonte: Cálculos do autor.

Nota: $\left({ }^{*}\right)$ = divisão por zero (o preço agrícola aumenta e o preço industrial permanece inalterado);

$(?)=$ resultado ambíguo

Verifica-se, na Tabela 7, que, quando se considera que há indexação apenas na formação do preço industrial, a política monetária melhora as relações de troca em favor da agricultura. No caso em que há indexação apenas na taxa de câmbio, o resultado da política monetária é ambíguo: qualquer um dos setores (agrícola ou industrial) pode ser favorecido nas relações de troca; o resultado depende, basicamente, das magnitudes dos pesos $\alpha_{1}$ e $\pi_{1}$. Se $\alpha_{1}<\pi_{1}$, então $d p_{A} / d p_{J}>1$, o que indica que o setor agricola é mais favorecido quando comparado ao setor industrial.

${ }^{24}$ A maioria desses cálculos foram feitos com auxílio do software MAPLE V (HECK, 1993). 
Quando há indexação perfeita da economia, as relações de troca permanecem inalteradas, ou seja, os preços agrícolas e industriais crescem na mesma proporção, em resposta a uma política monetária expansionista.

Os efeitos de uma operação de mercado aberto com títulos domésticos podem ser entendidos da seguinte forma: numa operação contracionista, por exemplo, que visa reduzir o estoque de moeda em circulação, o Banco Central doméstico oferta uma grande quantidade desses títulos ao setor privado. Esta oferta relativamente elevada reduz os preços de face desses títulos e aumenta sua taxa de retorno. As taxas de juros mais elevadas aumentam os custos de estocagem de bens agrícolas, resultando numa maior oferta destes bens e, conseqüentemente, numa queda em seus preços.

Os resultados obtidos dos efeitos de desvalorizações cambiais sobre o preço relativo agricultura-indústria foram claros apenas em duas situações: quando a indexação da economia é perfeita e quando há indexação apenas na formação dos preços industriais (ver Tabela 7). Nestes dois casos, as relações de troca melhoram em favor do setor industrial. Nas duas outras possíveis situações, os resultados obtidos foram ambíguos. Estes resultados dependem, basicamente, da magnitude de $\pi_{1}$, que é o parâmetro que mede a participação dos insumos agrícolas nos custos industriais.

\subsection{Comentários adicionais}

Os resultados das operações de mercado aberto com títulos domésticos (política monetária) dependem da forma de indexação considerada. Se existe indexação perfeita na economia, as operações de mercado aberto com títulos domésticos deixam inalteradas as relações de troca agricultura-indústria. Nas outras situações, excluindo-se o caso de ambigüidade que ocorre quando $\gamma=1$ e $\theta=0$, ou seja, há indexação apenas na taxa de câmbio, as relações de troca melhoram em favor da agricultura. 
Os efeitos de desvalorizações cambiais sobre o preço relativo agriculturaindústria foram ambíguos em duas das quatro formas de indexação consideradas. Essas ambigüidades ocorrem quando não há qualquer forma de indexação na economia ou quando há indexação apenas na taxa de câmbio. Os resultados dependem, basicamente, da proporção dos insumos agrícolas nos custos de produção industriais. Nas outras situações, as desvalorizações cambiais produziram efeitos relativos maiores nos preços industriais. ${ }^{25}$ Esses resultados foram obtidos na suposição de que a oferta monetária doméstica não é alterada, sendo, portanto, efeitos parciais.

Note-se que foram consideradas apenas quatro formas alternativas de indexação. Entretanto, os parâmetros de indexação, $\gamma$ (para a taxa de câmbio) e $\theta$ (para a determinação do preço industrial) podem variar entre zero e um. Existem, portanto, infinitas formas alternativas de indexação numa economia. Saber qual delas ocorreu num determinado período é uma questão empírica.

Um outro aspecto a ressaltar é que se supôs, no modelo teórico, que nenhuma esterilização é feita para neutralizar total ou parcialmente as mudanças nas fontes monetárias externas. Evidentemente que, dependendo dos objetivos da política econômica, alguma esterilização pode ser feita em algum momento. Essa questão merece um tratamento à parte, o que foge aos objetivos deste trabalho. ${ }^{26}$

Uma das grandes vantagens dos modelos de equilíbrio de portfolio é sua flexibilidade. Uma análise alternativa que pode ser feita a partir do modelo teórico desenvolvido neste capítulo é considerar a taxa nominal de juros doméstica exógena. $\mathrm{O}$ objetivo da política monetária, neste caso, seria o de controlar esta taxa em vez dos estoques de moeda ou títulos domésticos. Comentários sobre a análise de estática comparativa considerando esta possibilidade são feitas no Apêndice 1 deste estudo.

\footnotetext{
${ }^{25}$ Os resultados da análise de estática comparativa relaivivos às operações de mercado aberto com tutulos domésticos e às desvalorizações cambiais sobre os preços relativos agricultura-indústria são consistentes. de modo geral, com os encontrados por BARROS (1990). Este autor propôs um modelo teórico diferente do proposto neste capitulo, ou seja, seu modelo não é do tipo equilíbrio de portfolio.

${ }^{26}$ Ver, por exemplo, MONTEZANO (1989) para um tratamento específico desta questão.
} 
Um outro aspecto importante é que no modelo teórico desenvolvido neste capítulo não se pode determinar a priori qual dos efeitos das políticas (monetária ou cambial) é mais intenso sobre o termo doméstico de troca agricultura-indústria. Os resultados dependem dos valores assumidos pelos parâmetros. Em função disso, esta questão é melhor tratada empiricamente. 


\section{ANÁLISE EMPÍRICA: METODOLOGIA E RESULTADOS}

\subsection{Introdução}

Neste capítulo apresentam-se a metodologia utilizada e os resultados empíricos obtidos dos efeitos de choques monetários e cambiais sobre o preço relativo agricultura-indústria. A análise empírica, abrangendo o período de outubro de 1982 a dezembro de 1988, baseou-se teoricamente no modelo desenvolvido no capítulo 3 . Admitiu-se, ainda, que as autoridades monetárias podem, no curto prazo, exercer algum controle direto sobre a taxa de juros, podendo esta variável também sofrer choques.

Utilizaram-se modelos de auto-regressão vetorial (VAR) na investigação empírica dos efeitos de políticas monetárias e cambiais sobre o preço relativo agricultura-indústria. Estes modelos têm sido largamente utilizados na análise dos efeitos de políticas macroeconômicas sobre o setor agrícola. ${ }^{1}$ Nas seções seguintes, são discutidos os principais aspectos teóricos relacionados com os modelos VAR, iniciando, na seção 4.2 , com alguns conceitos, como raiz unitária, co-integração e modelo de correção de erro (MCE), que, sob determinadas condições, são importantes na implementação dos modelos VAR. Em seguida à discussão dos aspectos metodológicos, apresentam-se e discutem-se os principais resultados empíricos obtidos.

\footnotetext{
Ver, por exemplo, CHAMBERS (1984), BARROS (1992) e BRANDÃO \& ORDEN(1993).
} 


\subsection{Raiz unitária, co-integração e modelo de correção de erro (MCE) ${ }^{2}$}

Os conceitos de raiz unitária, co-integração e MCE estão estreitamente relacionados e serão apresentados a seguir.

\subsubsection{Raiz unitária}

O conceito de raiz unitária tem a ver com estacionariedade ou não de séries temporais. Uma série $X_{t}$ é estacionária se ela apresenta propriedades estatísticas invariantes no tempo, ou seja, a média de $X_{t}$, sua variância e sua covariância com outro valor de $X$, por exemplo $X_{t-k}(k \neq 0)$, não dependem de t. Ao contrário das séries nãoestacionárias, as séries estacionárias tendem a ser erráticas. ${ }^{3} \mathrm{~A}$ série ruído branco $e_{t}$ é um exemplo de uma série estacionária, pois as observações são independentes, a média é igual a zero e a variância é finita e constante.

Um problema imediato que surge quando se relacionam variáveis que não tenham uma relação estável de longo prazo num modelo de regressão, supondo-se que essas variáveis sejam estacionárias quando de fato elas não o são, é que estatísticas usuais como $\mathbf{R}^{2}$, DW e $\mathbf{t}$ de Student não mantêm suas características tradicionais. Os resultados de regressões com tais dados são espúrios. Ocorre que as séries econômicas de dados são, em geral, não-estacionárias. A abordagem BOX-JENKINS ${ }^{4}$ sugere que estas séries podem tornar-se estacionárias por diferenciação (uma operação do tipo

\footnotetext{
${ }^{2}$ Nesta seção sumarizam-se os principais aspectos relacionados com os conceitos de raiz unitária, cointegração e MCE. Há uma vasta literatura que trata deste assunto. Citam-se, como exemplos, os arigos de DOLADO et alii (1990), COCHRANE (1991) e CAMPBELL \& PERRON (1991) e os livros-textos de KENNEDY (1992) e HAMILTON (1994). Para uma aplicação destes conceitos a problemas agrícolas, ver, por exemplo, BACCHI \& HOFFMANN (1995) e WILLIAMS \& BEWLEY (1993).

${ }^{3} \mathrm{O}$ conceito refere-se a estacionariedade fraca. Note-se que uma série pode ser estacionária ao redor de uma tendência determinística.

${ }^{4}$ Ver BOX \& JENKINS (1970).
} 
$\Delta y_{t}=y_{t}-y_{t-1}$, em que $\Delta$ é o operador de defasagem), sendo necessárias uma ou duas diferenciações para tornar tais séries estacionárias.

O número de diferenciações necessárias para tomar uma série estacionária determina sua ordem de integração. ${ }^{5}$ Por exemplo, uma variável $y$ é dita ser integrada de ordem $d$, denotada por $I(d)$, se for necessário diferenciá-la $d$ vezes para torná-la estacionária. Dessa forma, uma variável estacionária é integrada de ordem zero, ou seja, $I(0)$, e uma variável que deve ser diferenciada uma única vez para se tomar estacionária é $I(1)$, ou seja, integrada de ordem um, e assim por diante.

Considere-se o exemplo do passeio aleatório (random walk), descrito pela seguinte equação:

$$
y_{t}=y_{t-1}+e_{t}
$$

em que o termo $e_{t}$ é um ruído branco, ou seja, uma série integrada de ordem zero, $I(0)$. Neste caso, $y$ é uma variável integrada de ordem um, $I(1)$, porque $\Delta y_{t}=e_{t}$, que é $I(0)$.

Considere-se, agora, que a variável $y$ seja gerada pelo seguinte processo auto-regressivo:

$$
y_{t}=\rho y_{t-1}+e_{t}
$$

Podem ocorrer as seguintes possibilidades: se $|\phi|<1$, então $y$ é $I(0)$, ou seja, estacionária, mas se $\rho=1$, então $y$ tem raiz unitária, ou seja, é não-estacionária. Note-se que o caso de $|\phi|>1$ é tido como pouco plausível em se tratando de séries econômicas porque descreveria uma situação em que a trajetória no tempo de $y_{t}$ seria explosiva.

Uma larga variedade de testes de raiz unitária têm sido desenvolvidos recentemente. ${ }^{6}$ A maioria desses testes requer o uso de distribuições especiais. Dentre os

\footnotetext{
5 O termo integração refere-se à operação inversa da diferenciação. Para obter uma previsão para $y$, por exemplo, é necessário integrar $\Delta y$, pois esta variável foi obtida por diferenciação de $y$.

${ }^{6}$ Ver, por exemplo, HAMILTON (1994) para uma descrição destes testes.
} 
procedimentos para testar raiz unitária, os propostos por FULLER (1976) e DICKEY \& FULLER (1979 e 1981) têm sido bastante utilizados. Visando testar raiz unitária, o processo auto-regressivo descrito pela equação (39), por exemplo, pode ser transformado pela subtração de $y_{t-1}$ de ambos os lados daquela equação para obter:

$$
\Delta y_{t}=(\rho-1) y_{t-1}+e_{t}
$$

que pode ser estimada por Mínimos Quadrados Ordinários (MQO). O teste de raiz unitária $(\rho=1)$ consiste em testar a seguinte hipótese nula:

$$
H_{0}:(\rho-1)=0
$$

Estacionariedade exige que: $(\rho-1)<0$. Se o processo gerador dos dados tiver mais do que uma defasagem de $y$ no lado direito de (39), ou seja, se o processo auto-regressivo for de ordem maior do que um, a transformação para fins de estimação e teste de raiz unitária requererá apenas a adição de um número apropriado de defasagens de $\Delta y$ s no lado direito da equação (40).

Numa abordagen genérica, considere-se que, em vez de uma defasagem (equação (39)), a série $y_{t}$ tenha $p$ defasagens. Acrescentado-se uma constante $\alpha$ e uma tendência $t$, tem-se:

$$
y_{t}=\alpha+\beta t+\rho_{1} y_{t-1}+\rho_{2} y_{t-2}+\ldots+\rho_{p} y_{t-p}+e_{t}
$$

Numa aplicação prática do teste de raiz unitária, convém determinar inicialmente o número de defasagens $p$ na equação (42) e testar as hipóteses: $H_{0}: \alpha=0$ e $H_{\bullet}: \beta=0$. O valor de $p$ pode ser obtido por tentativas, até que se consigam resíduos não correlacionados, ou utilizando alguns critérios como, por exemplo, o critério de informação de AKAIKE (AIC) e/ou o critério de SCHWARZ (SC) ${ }^{7}$ Alguns pacotes computacionais, como o Regression Analysis of Time Series (RATS), ${ }^{8}$ possuem rotinas que permitem determinar não só o número de defasagens de processos auto-

\footnotetext{
${ }^{7}$ Ver as fórmulas desses critérios de informação no Apêndice 2. Considera-se o menor valor obtido em cada um desses critérios quando são comparados modelos com diferentes defasagens.

${ }^{8}$ Ver DOAN (1992).
} 
regressivos utilizando os critérios AIC e SC como a ordem de integração de séries temporais.

Suponha-se que, utilizando os critérios AIC e SC, tenha-se determinado que a série $y_{t}$ é melhor representada por um processo auto-regressivo de ordem um. Neste caso, a equação (42) pode tomar as seguintes formas: ${ }^{9}$

$$
\begin{aligned}
& y_{t}=\alpha+\rho y_{t-1}+e_{t} \\
& y_{t}=\alpha+\beta t+\rho y_{t-1}+e_{t}
\end{aligned}
$$

Em DICKEY \& FULLER (1981, p.1062-1063) estão tabulados os valores críticos para testar as seguintes hipóteses: a) estatística $\tau_{\alpha \mu}$ para $H_{0}: \alpha=0$, na equação (43); e b) estatísticas $\tau_{\alpha \tau}$ e $\tau_{\beta \tau}$, respectivamente, para $H_{0}: \alpha=0$ e $H_{0}: \beta=0$, na equação (44). São também utilizadas as estatísticas $\Phi_{1}, \Phi_{2}$ e $\Phi_{3}$ para testar as seguintes hipóteses: $\Phi_{1}$ para $H_{0}:(\alpha, \rho)=(0,1)$, na equação $(43) ; \Phi_{2}$ para $H_{0}:(\alpha, \beta, \rho)=(0,0,1)$, na equação (44); e $\Phi_{3}$ para $H_{0}:(\alpha, \beta, \rho)=(\alpha, 0,1)$, na equação (44), cujos valores são obtidos por meio de uma distribuição $F$ modificada, ou seja, uma distribuição nãopadrão. Após esses testes, especifica-se uma equação apropriada para testar raiz unitária na série $y_{t}$, cujas distribuições e cujos valores críticos especiais dependem do fato de essa equação não ter constante nem tendência, ter constante apenas ou ter constante e tendência.

Admitindo-se que o modelo que descreve a série $y_{t}$ tenha uma constante $\alpha$ e um tendência $t$, então a equação para o teste de raiz unitária é dada por: ${ }^{10}$

$$
\Delta y_{t}=\alpha+\beta t+\left(\sum_{i=1}^{p} \rho_{i}-1\right) y_{t-1}-\sum_{i=1}^{p-1} \sum_{j=i+1}^{p} \rho_{j} \Delta y_{t-i}+e_{t}
$$

\footnotetext{
${ }^{9}$ A equação (39) seria o caso em que $\alpha=0$ e $\beta=0$.

${ }^{10}$ Está-se considerando o caso geral de um processo auto-regressivo com $p$ defasagens.
} 
Para testar a hipótese de raiz unitária, deve-se calcular o valor de $t$ relativo a esta hipótese de maneira usual. A distribuição dessa estatística, entretanto, não é a do $\mathbf{t}$ de Student, sendo necessário utilizar distribuições especiais. Os valores críticos para esse teste estão tabulados em $\operatorname{FULLER}(1976$, p.373). No caso da equação (45), a estatística a ser usada é a $\tau_{\tau}$ (equação com constante e com tendência); $\tau_{\mu}$ seria usada numa equação com uma constante apenas; e $\tau$ seria usada numa equação sem constante e sem tendência. Dado um determinado nivel de probabilidade ( $5 \%$ ou menos, por exemplo), se o valor calculado de $t$ relativo à hipótese nula for negativo e maior, em módulo, que o valor crítico, rejeita-se a hipótese nula e indica-se que a série é $I(0)$. Caso contrário, testa-se raiz unitária no modelo:

$$
\Delta^{2} y_{t}=\alpha+\beta t+\left(\sum_{i=1}^{p} \rho_{i}-1\right) \Delta y_{t-1}-\sum_{i=1}^{p-1} \sum_{j=i+1}^{p} \rho_{j} \Delta^{2} y_{t-i}+e_{t}
$$

para verificar se a série é $I(1)$, ou seja, integrada de ordem um. Se a hipótese de raiz unitária mais uma vez for aceita, repete-se o processo até que esta hipótese seja rejeitada.

Convém ressaltar que FULLER (1976) formulou os testes de raiz unitária sob a hipótese de que os resíduos são idêntica e independentemente distribuídos (iid). Quando os resíduos apresentam correlação serial, utilizam-se os testes propostos por PHILLIPS (1987) e PHILLIPS \& PERRON (1988), que consistem nas estatísticas de FULLER submetidas a ajustes não-paramétricos que relaxam a hipótese de erros iid. Para os testes de PHILLIPS-PERRON, utilizam-se os mesmos valores críticos obtidos por FULLER (1976). Note-se também que os valores críticos para os testes de raiz unitária independem do número de defasagens consideradas. Se $p \geq 2 \mathrm{em}$ (45), o teste, em vez de DICKEY-FULLER, é chamado de DICKEY-FULLER expandido. 


\subsubsection{Co-integração}

Duas ou mais variáveis são ditas serem co-integradas se existir relação estável de longo prazo entre elas. Essas variáveis devem ter a mesma ordem de integração. Forças de equilíbrio tendem a fazer com que estas variáveis movam-se juntas, no longo prazo. A teoria econômica identifica diversas relações entre variáveis que podem ser submetidas a testes empíricos. Alguns exemplos dessas relações, citados por KENNEDY (1992, p.254), são taxas de juros de curto e longo prazos, importação e exportação, renda doméstica e dispêndio, preços e salários, preços spot e futuro de commodities, e taxas de câmbio determinadas em diferentes mercados.

Segundo ENGLE \& GRANGER (1987), os componentes de um vetor $x_{t}$ são ditos serem co-integrados de ordem $(d, b)$, denotado por $C I(d, b)$, se: a) todos os componentes de $x_{t}$ são $I(d)$; e b) existe uma combinação linear destes componentes, que é $I(d-b), b>0$. Os parâmetros desta combinação determinam um vetor de cointegração. No caso em que $d=b=1$, todos os componentes do vetor $x_{t}$ são $I(1)$ e existe uma combinação linear destes componentes, que é $I(0)$. Esta combinação linear é interpretada como uma relação de equilíbrio.

Considere-se que o vetor $x_{t}=\left(x_{1 t}, x_{2 t}, \ldots, x_{k t}\right)^{\prime}$ tenha uma relação de equilíbrio de longo prazo dada por: $\alpha^{\prime} x_{t}=\alpha_{1} x_{1 t}+\ldots+\boldsymbol{\alpha}_{k} x_{k t}=0$. Em geral, é plausível supor que uma economia encontra-se freqüentemente mais fora do equilibrio do que em equilíbrio. Dessa forma, pode ocorrer que: $\alpha^{\prime} x_{t}=v_{t}$, em que $v_{t}$ é uma variável estocástica representando o desvio do equilíbrio. Se existe relação de co-integração entre os componentes do vetor $x_{t}$, é razoável supor que $v_{t}$ é estacionária. Se de fato isto ocorre, diz-se que as variáveis do vetor $x_{t}$ são co-integradas.

Antes de testar co-integração, deve-se determinar a ordem de integração das variáveis que serão relacionadas. Como já assinalado, estas variáveis devem ter a 
mesma ordem de integração. $O$ teste de co-integração consiste em verificar se $\varepsilon_{t}$, de uma equação de co-integração da forma:

$$
x_{1 t}=\delta_{0}+\delta_{2} x_{2 t}+\ldots+\delta_{k} x_{k t}+\varepsilon_{t}
$$

é estacionária, ou seja, se $\varepsilon_{t}=x_{1 t}-\delta_{0}-\delta_{2} x_{2 t}-\ldots-\delta_{k} x_{k t}$ é $I(0)$. O teste de raiz unitária é também aplicado neste caso. Utilizam-se os mesmos procedimentos descritos anteriormente, só que agora a série a ser testada é a do resíduo $\varepsilon_{t}$. Entretanto, o teste de raiz unitária para co-integração requer distribuições especiais diferentes daquelas de um simples teste de raiz unitária. Essas distribuições encontram-se tabuladas em ENGLE \& GRANGER (1987) e ENGLE \& YOO (1987).

Se um vetor de variáveis co-integradas possui mais do que duas variáveis, surgem dois problemas: primeiro, ao estimar uma regressão de co-integração, uma das variáveis deve ser escolhida para ser dependente e seu coeficiente é igual a um, ${ }^{11}$ segundo, é possível que exista mais do que uma relação de co-integração entre as variáveis. JOHANSEN (1988) discute este segundo problema e sugere um procedimento alternativo para estimar as relações de co-integração. Este procedimento baseia-se na seguinte versão reparametrizada de um VAR $(p)$, ou seja, um vetor de auto-regressão vetorial com $p$ defasagens:

$$
\Delta x_{t}=\Gamma_{1} \Delta x_{t-1}+\ldots+\Gamma_{p-1} \Delta x_{t-p+1}+\Pi x_{t-1}+\mu+e_{t}
$$

em que $x_{t}$ é um vetor $(k \times 1)$ de variáveis estocásticas, $e_{t}$ são erros iid $N(0, \Sigma)$ e $\Pi=\alpha \beta$. $\alpha$ e $\beta$ são matrizes $(k \times r)$, sendo $r$ o posto da matriz $\Pi$, que é igual ao número de vetores de co-integração linearmente independentes. Os parâmetros do modelo (48) são estimados por meio da maximização da função de verossimilhança.

O número de relações (vetores) de co-integração é igual ao número de raízes características $(\lambda)$ estatisticamente diferentes de zero. Podem ocorrer as seguintes possibilidades: a) $r=k$, então o vetor $x_{t}$ é estacionário; b) $r=0$, então $\Delta x_{t}$ é

${ }^{11}$ Os parâmetros de co-integração estimados podem ser sensiveis a esta normalização. 
estacionário; e c) $0<r<k$, então existem matrizes $\alpha$ e $\beta$ tais que $\Pi=\alpha \beta$. JOHANSEN \& JUSELIUS (1990) propuseram dois testes (teste do traço e do $\lambda_{\max }$ ) assim como seus valores críticos, para identificar o número de vetores de co-integração.

\subsubsection{Modelo de correção de erro (MCE)}

Quando se diferencia uma série econômica para torná-la estacionária, perdem-se informações de longo prazo, sendo necessário, para contornar esse problema, introduzir um mecanismo de correção de erro. Os modelos de correção de erro são especificados de forma a considerar as relações de equilíbrio de longo prazo estabelecidas pela teoria econômica e os desvios em relação a este equilíbrio. Nesse sentido, o modelo (48) é um MCE. Um aspecto importante desses modelos é que as variáveis são consideradas tanto em nível como nas primeiras diferenças.

Como exemplo, considere-se o seguinte modelo: ${ }^{12}$

$$
y_{t}=\alpha_{0}+\alpha_{1} x_{t}+\alpha_{2} x_{t-1}+\alpha_{3} y_{t-1}+e_{t}
$$

em que, por suposição, as variáveis $y$ e $x$ crescem à mesma taxa no longo prazo, tal que, em equilíbrio, $(y-x)$ é igual a uma constante. A equação (49) pode ser manipulada para gerar o seguinte MCE: ${ }^{13}$

$$
\Delta y_{t}=\alpha_{0}+\alpha_{1} \Delta x_{t}+\left(\alpha_{3}-1\right)\left(y_{t-1}-x_{t-1}\right)+e_{t}
$$

O penúltimo termo de (50) é o mecanismo de correção de erro e reflete desvios do equilíbrio de longo prazo. $\mathrm{O}$ termo $\alpha_{1} \Delta x_{t}$ reflete as respostas a esse equilíbrio. Supondo-se que as variáveis $y$ e $x$ são integradas de ordem um, então, para que a estimação do modelo (50) não produza resultados espúrios, é necessário que as variáveis

\footnotetext{
${ }^{12}$ Ver KENNEDY (1992, p. 251).

${ }^{13}$ Para obter (50) a partir (49), subtraiu-se $y_{t-1}$ de ambos os lados de (49) e adicionou-se $\alpha_{1} x_{t-1} \mathrm{e}$ subtraiu-se $\left(\alpha_{3}-1\right) x_{t-1}$ no lado direito de (49).
} 
em nível sejam co-integradas, de forma que $\left(y_{t-1}-x_{t-1}\right)$ seja integrada de ordem zero, o que é consistente com as variáveis nas primeiras diferenças.

Visando uma aplicação prática dos conceitos de raiz unitária, cointegração e MCE seguem-se os seguintes passos: a) definir, com base na teoria econômica, o conjunto de variáveis que comporão o modelo; b) realizar o teste de raiz unitária para determinar a ordem de integração das variáveis; c) obter as relações de cointegração, dado o conjunto de variáveis; e d) se existirem relações de co-integração, adicionar o(s) termo(s) de correção de erro e estimar o modelo na forma de um MCE, principalmente se há interesse em análises de curto prazo. É necessário, para obter resultados não espúrios, que, nesse modelo, tanto as variáveis nas diferenças como 0 termo de correção de erro (se este existir) sejam estacionários.

\subsection{Modelo de auto-regressão vetorial (VAR)}

O uso de modelos VAR na análise dinâmica de sistemas econômicos foi popularizado por SIMS (1980). Estes modelos têm-se mostrado bastante convenientes para previsão e permitem, na sua forma convencional, fazer análises dinâmicas sem a necessidade de especificar previamente um modelo teórico que mostre como as variáveis se relacionam intertemporalmente, fazendo com que os dados, neste caso, desempenhem um papel importante na especificação da estrutura dinâmica do modelo. Uma vez estimado um modelo VAR, podem-se obter e analisar: a) as elasticidades de impulso; e b) a decomposição da variância do erro de previsão $l$-períodos à frente.

$\mathrm{Na}$ análise das elasticidades de impulso obtidas a partir de um modelo VAR convencional ${ }^{14}$ na forma de médias móveis, ${ }^{15}$ requer-se que a matriz de variânciacovariância dos resíduos seja diagonal, pois isto permite que se verifique o efeito de um

\footnotetext{
${ }^{14}$ Para um exemplo de uma aplicação deste modelo, ver BRANDÃO (1985).

15 O teorema de WOLD (citado por BRANDÃO (1985, p. 38)) assegura que todo processo estacionário não determinístico tem uma representação de médias móveis.
} 
choque em apenas uma das variáveis sobre o sistema. Ocorre que, em geral, essa matriz não é diagonal, o que significa que choques contemporâneos podem afetar mais de uma das variáveis. Para contornar este problema, tem-se utilizado o método de decomposição de CHOLESKY para diagonalizar a matriz de variância-covariância dos resíduos. Entretanto, os resultados relativos à decomposição da variância do erro de previsão têmse mostrado, em geral, sensíveis à ordenação das variáveis no sistema.

Isso ocorre porque o sistema de variáveis tem que ser tomado como recursivo do ponto de vista estrutural, sendo que, em geral, desconhece-se a ordem de recursividade. Por exemplo, num sistema de quatro variáveis, na decomposição da variância, as inovações na primeira variável da seqüência afetam as demais variáveis contemporaneamente, mas não é afetada por inovações nestas variáveis; a segunda variável afetará contemporaneamente a terceira e quarta, não sendo afetada por estas; e assim por diante. Dado que há uma certa arbitrariedade na ordenação das variáveis no sistema, este procedimento tem recebido críticas.

Uma vez que os modelos VAR convencionais têm sido usados sob pressupostos bastante restritivos, diversos procedimentos alternativos têm sido propostos, como, por exemplo, os de BLANCHARD \& WATSON (1984), BERNANKE (1986) e SIMS (1986). Estes procedimentos alternativos buscam uma melhor especificação estrutural do modelo, que é obtida junto à teoria econômica relevante. Dessa forma, não só os dados, como as informações da teoria econômica, são relevantes na especificação da estrutura dinâmica do modelo. Daí a importância do modelo teórico desenvolvido no capítulo 3 para a análise empírica que é levada a efeito neste capítulo.

Neste estudo, segue-se o procedimento proposto por ORDEN \& FACKLER (1989). ${ }^{16}$ Estes autores concentram as restrições de identificação na matriz de interações contemporâneas do modelo, não impondo quaisquer restrições nas variáveis defasadas. Uma justificativa para tal procedimento é que a teoria econômica

\footnotetext{
${ }^{16}$ Este procedimento foi também utilizado por BARROS (1991 e 1992) e AGUIAR (1994).
} 
define com maior rigor as relações contemporâneas do que as interações de defasagem. Admite-se, também, que as realizações passadas das variáveis são de conhecimento dos agentes econômicos, podendo ser utilizadas na formulação de expectativas.

Na sua formulação geral, o modelo auto-regressivo é dado por: ${ }^{17}$

$$
A_{0} y_{t}=\sum_{s=1}^{p} A_{s} y_{t-s}+B_{0} v_{t}, \quad s=1,2, \ldots, p
$$

em que $y_{t}$ é um vetor $(k x 1)$ das variáveis incluídas no modelo; $A_{0}$ é a matriz $(k x k)$ de coeficientes das relações contemporâneas; $A_{s}$ são matrizes $(k x k)$ de relações com defasagem $s ; v_{t}$ é um vetor de erros aleatórios suposto ortogonal e que tem distribuição multinormal, com matriz de variância-covariância $\operatorname{Cov}\left(v_{t}\right)=D$ diagonal; e $B_{0}$ é uma matriz identidade $(k \times k)$.

A matriz $A_{0}$, que é importante para se obter a forma reduzida de (51), será especificada com base no modelo teórico desenvolvido no capítulo 3 . Multiplicando-se ambos os lados da expressão (51) pela inversa da matriz de coeficientes de interações contemporâneas $\left(A_{0}^{-1}\right)$, obtém-se a forma reduzida:

$$
y_{t}=\sum_{s=1}^{p} A_{0}^{-1} A_{s} y_{t-s}+A_{0}^{-1} v_{t}
$$

O sistema de equações dado por (52) pode ser estimado por Mínimos Quadrados Ordinários (MQO) para obter os resíduos:

$$
u_{t}=A_{0}^{-1} v_{t}
$$

cuja matriz de variância-covariância é $\operatorname{Cov}\left(u_{t}\right)=\Omega$. Esta matriz será utilizada para estimar $A_{0}^{-1} . \Omega$ possui $k(k+1) / 2$ parâmetros livres, sendo este o número máximo de parâmetros que podem ser estimados em $A_{0}$. O número mínimo de restrições que precisam ser impostas para identificação é igual a $k(k-1) / 2$. Note-se que o modelo VAR recursivo é exatamente identificado, pois a matriz $A_{0}$, nesse modelo, é triangular

${ }^{17}$ Ver SIMS (1986). 
inferior com $k(k+1) / 2$ parâmetros. No caso de haver um número menor de restrições, tem-se um modelo subidentificado; caso contrário, tem-se um modelo superidentificado.

$\mathrm{Na}$ estimação do modelo geral dado por (51), pode-se utilizar o procedimento de BERNANKE que se acha incorporado ao software RATS. Numa segunda etapa do processo de estimação, maximiza-se a função logarítmica de verossimilhança dos resíduos obtidos da estimação por MQO de (52), ou seja:

$$
\ln L=-T(k / 2) \ln (2 \pi)+T\left(\left|\ln A_{0}\right|-0,5 \ln |D|\right)-(T / 2) \operatorname{tr}\left(D^{-1} A_{0} \Omega A_{0}^{\prime}\right)
$$

em que $T$ é igual ao número de observações. No procedimento de BERNANKE, a matriz $\Omega$ é substituída por $T$ vezes a matriz de produtos residuais cruzados. Para maximizar a função (54), utiliza-se o método de NEWTON, pois as condições de primeira ordem são quadráticas. ${ }^{18}$

Uma vez estimadas as matrizes $A_{0}$ e $D$, podem-se analisar as respostas de cada variável aos choques em quaisquer das variáveis do sistema e a decomposição da variância dos erros de previsão. Escrevendo-se o modelo auto-regressivo na forma de médias móveis, tem-se:

$$
y_{t}=\sum_{s=0}^{\infty} C_{s} u_{t-s}
$$

em que $C_{s}$ são matrizes que medem os impactos dos respectivos vetores de erros. $\mathrm{O}$ modelo (55) pode ser reescrito na forma:

$$
y_{t}=\sum_{s=0}^{\infty} C_{s} A_{0}^{-1} D^{1 / 2} v_{t}
$$

Os choques unitários em $v_{t}$ multiplicados pela raiz quadrada de $D$ equivalem a choques de um desvio-padrão. Caso as variáveis sejam medidas na forma logarítmica, os efeitos desses choques podem ser vistos como elasticidades. Note-se que, se uma variável não é contemporaneamente relacionada a qualquer outra no modelo, o

${ }^{18}$ FACKLER (1988) discute detalhadamente as etapas envolvidas no processo de maximização. 
choque inicial no seu erro terá impacto de igual magnitude sobre ela mesma, sendo diferente se ela relacionar-se contemporaneamente a outras variáveis do modelo. A decomposição da variância dos erros de previsão é também obtida a partir de (56), ignorando-se os efeitos de erros amostrais nas estimativas dos coeficientes.

\subsection{Análise dos resultados}

$\mathrm{Na}$ implementação de um modelo VAR, devem-se definir inicialmente as variáveis que comporão o modelo e o número de defasagens que serão consideradas. $\mathrm{O}$ modelo teórico desenvolvido no capítulo 3 será útil na definição dessas variáveis. Naquele modelo, consideraram-se as seguintes variáveis: títulos externos (reservas internacionais), títulos domésticos, moeda criada pelo Banco Central (crédito doméstico líquido), taxa de câmbio, taxa nominal de juros e índices de preços agrícola e industrial.

Note-se que nas operações de mercado aberto substitui-se moeda por título doméstico, de forma que essas variáveis acham-se altamente correlacionadas. Em função disso, optou-se por utilizar, na análise empírica, apenas um desses agregados financeiros, recaindo a escolha sobre o estoque de moeda ${ }^{19} \mathrm{O}$ restante das variáveis do modelo teórico, ou seja, a taxa de câmbio, a taxa nominal de juros e os índices de preços domésticos, foi considerado na análise empírica.

Para definir o número de defasagens do modelo VAR, utilizaram-se os critérios de SCHWARZ (SC), de HANNAN-QUINN (HQ), de informação de AKAIKE (AIC) e o critério do erro de predição final (FPE) ${ }^{20}$ Utilizou-se o software RATS para calcular os valores desses critérios, assim como para os testes relativos à raiz unitária, identificação de relações de co-integração e estimação dos modelos VAR com as

\footnotetext{
${ }^{19}$ CHAMBERS (1984) também desenvolveu um modelo teórico de equilibrio de portfolio e considerou. na análise empírica, como agregado financeiro, apenas o estoque de moeda.

20 Ver as fórmulas desses critérios no Apêndice 2. Considera-se o menor valor em cada um desses critérios quando são comparados o mesmo modelo VAR com diferentes defasagens.
} 
variáveis em nível ou na forma de MCE. Um outro teste que tem sido utilizado para definir o número de defasagens em um modelo VAR é o de razão de verossimilhança.

Os critérios de informação citados anteriormente, assim como o teste de razão de verossimilhança, são muito úteis na medida em que ajudam a especificar melhor os modelos, evitando-se, por exemplo, utilizar defasagens desnecessárias.

\subsubsection{Fonte dos dados}

$\mathrm{Na}$ análise empirica, as variáveis foram definidas da seguinte forma:

$\mathrm{TC}=$ taxa de câmbio real;

M1 = estoque nominal de moeda (moeda em poder do público mais depósitos à vista no sistema bancário);

$\sqrt{N}=$ taxa nominal de juros doméstica; e

$\mathrm{RP}=$ preço relativo agricultura-indústria (índice de preços agrícola dividido pelo índice de preços industrial, ambos por atacado).

Existem diversos indicadores sugeridos na literatura para a taxa de câmbio real. ${ }^{21}$ Um indicador bastante utilizado em análises empíricas é a taxa de câmbio real efetiva que é calculada levando em conta uma cesta de moedas que é ponderada de acordo com a participação dos principais parceiros comerciais do país em que se está apurando a taxa de câmbio. Segundo ZINI JR. (1993), esse indicador é o mais apropriado para avaliar a política cambial, porque um país, em geral, transaciona com diversos países e as discussões sobre sua taxa de câmbio devem levar em conta o que acontece com a média das relações de preços com esses países.

\footnotetext{
${ }^{21}$ Ver, por exemplo. ZINI JR. (1993) para uma discussão desses indicadores da taxa de câmbio real e de como calculá-los.
} 
Utilizou-se na investigação empírica desenvolvida neste capítulo o índice da taxa de câmbio real efetiva calculado pela Fundação Getúlio Vargas (FGV). Este índice considera uma cesta de 7 (sete) moedas com as seguintes ponderações: Dolar americano $(0,32660)$, Iene $(0,15467)$, Marco $(0,16230)$, Franco francês $(0,08314)$, Lira $(0,08842)$, Libra $(0,08032)$ e Florim $(0,10455)$. No cálculo desse índice foi utilizado como deflator doméstico o índice de preços por atacado industrial e para os demais países foi utilizado o índice de preços por atacado.

Considerou-se, como base para o índice da taxa de câmbio real efetiva, março/85=100. De acordo com ZINI JR. (1993, p. 33), há diversas evidências que sugerem que em 1985 a taxa de câmbio esteve relativamente alinhada com a competitividade externa do país, dentre as quais citam-se: o balanço de pagamentos equilibrado, o baixo ágio do dólar no mercado paralelo e os estudos relativos à proteção efetiva no Brasil, que mostram uma situação com poucas distorções naquele ano. Escolheu-se março por ser um mês em que começa a colheita de grandes safras em algumas regiões do país, de forma que os preços agrícolas não estão nem no seu pico nem no seu mínimo.

Utilizou-se como agregado monetário $\mathrm{Ml}$, tendo em vista que este conceito tem sido largamente utilizado em estudos empíricos e é consistente com o modelo teórico desenvolvido no capítulo 3. Este agregado é mensurado em reais. A taxa nominal de juros utilizada é a taxa de financiamento dos títulos públicos (média composta bruta). Os índices de preços por atacado domésticos (agrícola e industrial) foram considerados no seu conceito oferta global. Todos esses dados estão no Apêndice 3 e foram obtidos do Banco de Dados Conjuntura Eletrônica da Fundação Getúlio Vargas. $^{22}$

Cada série de dados contém 75 observações (o período da análise empírica está compreendido entre outubro de 1982 e dezembro de 1988). ${ }^{23}$ As séries TC

\footnotetext{
${ }^{22}$ Estes dados estão disponiveis em disquetes e são periodicamente atualizados.

${ }^{23}$ Ver capítulo 1 (Introdução) para as justificativas em utilizar esse período na análise empirica.
} 
e RP estão na forma de índices (base março/85=100). Na investigação empírica, tomouse o logaritmo neperiano das quatro séries consideradas. Convém observar que, embora seja usual não tomar o logaritmo de séries de taxas de juros em análises empíricas, tomou-se o logaritmo dessa série por problemas operacionais, ou seja, surgiram sérios problemas de convergência na estimação dos modelos VAR quando se deixou de tomar o logaritmo dessa série. Além disso, como se está trabalhando com taxas de juros nominais, não há observações negativas que impeçam de tomar o logaritmo.

\subsubsection{Modelo VAR com as variáveis em nível}

Embora os resultados dos testes de raiz unitária e co-integração (que serão apresentados adiante) tenham sugerido a utilização de um MCE, optou-se por apresentar e discutir os resultados obtidos tanto com o modelo VAR com as variáveis em nível quanto com o modelo VAR na forma de MCE. Os resultados obtidos com estes dois modelos podem ser comparados para se verificar em que extensão diferem um do outro. HAMILTON (1994, p.651-653) recomenda este tipo de procedimento.

Segundo HAMLTON (1994), se um modelo VAR possui algumas variáveis que podem ser não-estacionárias, tem-se que: a) os parâmetros estimados do modelo com as variáveis em nivel são consistentes; b) certas funções dos parâmetros e testes de hipóteses baseados num modelo VAR em nível têm as mesmas distribuições assintóticas, como se fossem baseadas com os dados nas diferenças; c) se os testes de raiz unitária e co-integração indicam que a melhor especificação é um MCE, pode-se ter cometido erros, como: aceitado uma hipótese nula sendo ela falsa ou rejeitado uma hipótese nula sendo ela verdadeira. Um outro aspecto é que os resultados de testes alternativos para raiz unitária e co-integração podem ser conflitantes. ${ }^{24}$

\footnotetext{
${ }^{24}$ Um ponto que tem sido também destacado são as baixas potências dos testes de raiz unitána. Para raizes próximas de um, por exemplo. esses testes freqüentemente indicarão que a série contém raiz unitána.
} 
Definidas as variáveis que comporão o modelo $\mathrm{VAR}$, pode-se proceder à identificação da matriz de interações contemporâneas $A_{0}$. As 4 variáveis foram ordenadas da seguinte forma: TC foi considerada mais exógena em relação às demais e aparece na posição (1,1); M1 aparece na posição $(2,2)$, mas é influenciada por TC; assim, na posição $(2,1)$ deve aparecer um coeficiente diferente de zero; na posição $(3,3)$ aparece a variável JN que é influenciada por $\mathrm{M} 1$, cujos efeitos serão captados na posição $(3,2)$; RP foi colocada na posição $(4,4)$, sendo influenciada pelas variáveis TC e $\mathrm{JN}$, cujos efeitos serão captados nas posições $(4,1)$ e $(4,3)$, respectivamente.

Para identificar o número de defasagens do modelo VAR a partir dos critérios de informação citados (AIC, HQ, SC e FPE), variou-se este número de 1 a 10 defasagens. Na Tabela 8 apresentam-se os resultados obtidos.

Tabela 8 - Critérios de informação para escolha do número de defasagens (p)do VAR

\begin{tabular}{ccccc}
\hline $\mathrm{p}$ & $\mathrm{FPE}(\mathrm{p})$ & $\mathrm{AIC}(\mathrm{p})$ & $\mathrm{HQ}(\mathrm{p})$ & $\mathrm{SC}(\mathrm{p})$ \\
\hline 01 & $0,10350 \mathrm{E}-08$ & $-20,690$ & $-20,441$ & $-20,067$ \\
02 & $0,11813 \mathrm{E}-08$ & $-20,562$ & $-20,112$ & $-19,432$ \\
03 & $0,15507 \mathrm{E}-08$ & $-20,301$ & $-19,646$ & $-18,656$ \\
04 & $0,11229 \mathrm{E}-08$ & $-20,645$ & $-19,783$ & $-18,478$ \\
05 & $0,10792 \mathrm{E}-08$ & $-20,723$ & $-19,651$ & $-18,025$ \\
06 & $0,48845 \mathrm{E}-09$ & $-21,578$ & $-20,293$ & $-18,340$ \\
07 & $0,48710 \mathrm{E}-09$ & $-21,675$ & $-20,175$ & $-17,889$ \\
08 & $0,51067 \mathrm{E}-09$ & $-21,770$ & $-20,051$ & $-17,427$ \\
09 & $0,40299 \mathrm{E}-09$ & $-22,217$ & $-20,277$ & $-17,307$ \\
10 & $0,42170 \mathrm{E}-09$ & $-22,482$ & $-20,317$ & $-16,996$ \\
\hline
\end{tabular}

Fonte: Dados da pesquisa.

Pelos critérios HQ e SC haveria 1 defasagem no VAR, enquanto pelo critério FPE haveria 9 defasagens. Já o critério AIC indica 10 defasagens, ou seja, o limite máximo considerado para o número de defasagens. Em vista dessas diferenças marcantes entre os critérios de informação, realizou-se o teste de razão de verossimilhança para o caso de um VAR convencional (exatamente identificado). Os resultados mostraram que não há diferença significativa (nível de $5 \%$ de probabilidade) 
entre modelos VAR com 10 e 5 defasagens e modelos VAR com 8 e 4 defasagens. Entretanto, existe diferença significativa entre um VAR com 6 defasagens e um com 3 defasagens.

Optou-se por trabalhar com duas especificações: uma com 3 e a outra com 6 defasagens. Estas defasagens foram consideradas tanto para o modelo VAR em nivel como para o modelo VAR na forma de MCE. Em tentativas para utilizar um número menor de defasagens, houve problemas de convergência na estimação do modelo VAR quando se considerou a taxa nominal de juros numa posição mais exógena na matriz de interações contemporâneas $\left(\mathrm{A}_{0}\right)$. Como a taxa de juros exerce um papel importante neste trabalho, considerou-se 3 como o menor número de defasagens.

Os coeficientes estimados da matriz $A_{0}$ do modelo VAR com 3 e 6 defasagens (variáveis em nível) são apresentados na Tabela 9. Estes coeficientes fornecem os efeitos imediatos e parciais (contemporâneos) de choques nas diversas variáveis explicativas sobre as variáveis dependentes. Convém observar que os sinais dos coeficientes fora da diagonal principal da Tabela 9 devem ser trocados para uma interpretação correta dos efeitos contemporâneos. Note-se que esses resultados mostram-se bastante satisfatórios em termos de sinais. Considerando-se o nivel de significância usual ( $5 \%$ de probabilidade), verifica-se que apenas o coeficiente de M1 (coluna 2), na equação de JN (linha 3), e o coeficiente de TC (coluna 1), na equação de RP (linha 4), foram estatisticamente significativos. 
Tabela 9 - Matrizes de interações contemporâneas $\left(\mathrm{A}_{0}\right)$ dos modelos VAR com 3 e 6 defasagens (variáveis em nível)*

\begin{tabular}{|c|c|c|c|c|}
\hline \multirow{2}{*}{$\begin{array}{l}\text { Equações } \\
\text { (3 defasagens) }\end{array}$} & \multicolumn{4}{|c|}{ Variáveis Explicativas } \\
\hline & TC & M1 & JN & $\mathrm{RP}$ \\
\hline TC & 1 & & & \\
\hline M1 & $\begin{array}{l}-0,0486 \\
(0,3447)\end{array}$ & 1 & & \\
\hline $\mathrm{JN}$ & & $\begin{array}{c}1,7962 \\
(0,3505)\end{array}$ & 1 & \\
\hline RP & $\begin{array}{c}-0,3507 \\
(0,1711) \\
\end{array}$ & & $\begin{array}{c}0,0025 \\
(0,0168) \\
\end{array}$ & 1 \\
\hline Equações & & Variá & licativas & \\
\hline ( 6 defasagens) & $\mathrm{TC}$ & M1 & JN & $\mathrm{RP}$ \\
\hline TC & 1 & & & \\
\hline M1 & $\begin{array}{l}-0,2341 \\
(0,3938)\end{array}$ & 1 & & \\
\hline $\mathrm{JN}$ & & $\begin{array}{c}1,5328 \\
(0,3372)\end{array}$ & 1 & \\
\hline $\mathrm{RP}$ & $\begin{array}{l}-0,7767 \\
(0,1956)\end{array}$ & & $\begin{array}{l}-0,0085 \\
(0,0187)\end{array}$ & 1 \\
\hline
\end{tabular}

Fonte: Dados da pesquisa.

Nota: $\left({ }^{*}\right)$ Entre parênteses estão as estimativas do desvio-padrão de cada coeficiente

À exceção do sinal do coeficiente de $\mathrm{JN}$, na equação de $\mathrm{RP}$, que apresenta sinal contrário e o parâmetro é estatisticamente não-significativo, os coeficientes estimados e seus respectivos desvios-padrões nos dois modelos VAR ( 3 e 6 defasagens) são muito semelhantes. Vale ressaltar, neste ponto, que na interpretação dos coeficientes estimados da matriz de interações contemporâneas tem-se dado maior importância aos sinais dos coeficientes do que às suas significâncias estatísticas. Por exemplo, verifica-se em qualquer dos dois modelos (com 3 ou 6 defasagens) que um aumento no estoque de moeda (um aumento em M1) reduz a taxa nominal de juros (JN), o que é consistente com o modelo teórico desenvolvido no capítulo 3 e que fornece o suporte teórico para esta análise. Note-se também que a inversão de sinais de coeficientes estimados entre 
modelos com diferentes defasagens (por exemplo, coeficiente de JN na equação RP) ocorreu no caso de coeficientes estatisticamente não-significativos.

A interpretação da tabela anterior é a seguinte (considerando o modelo VAR com 3 defasagens): um aumento não esperado de $10 \%$ (desvalorização) na taxa de câmbio real provoca uma elevação imediata de $0,49 \%$ em Ml e um aumento imediato de $3,51 \%$ no preço relativo agricultura-indústria. Possivelmente esta elevação do estoque de moeda deve-se ao aumento das exportações e conseqüente aumento do nível de reservas. No caso do aumento do preço relativo, uma explicação possível é que os preços agricolas, em razão da arbitragem internacional, respondem mais rapidamente à variação na taxa de câmbio do que os preços industriais, que estão sujeitos, em geral, a contratos de médio e longo prazo e, em função disso, o ajustamento é mais lento.

Verifica-se, também, na tabela anterior que um aumento de $10 \%$ no estoque nominal de moeda (M1) reduz imediatamente a taxa nominal de juros em $17,96 \%$. O impacto imediato sobre o preço relativo agricultura-indústria de um aumento de $10 \%$ na taxa nominal de juros é uma redução de $0,03 \%$ nesse preço, o que também é consistente com o modelo teórico desenvolvido no capítulo anterior. Procede-se da mesma forma na interpretação dos coeficientes estimados no modelo VAR com 6 defasagens. Dos resultados obtidos nos dois modelos, o impacto imediato mais significativo foi o da expansão monetária não esperada sobre a taxa nominal de juros.

$\mathrm{Na}$ Tabela 10 mostram-se as elasticidades de impulso dos modelos VAR com 3 e 6 defasagens (variáveis em nível). Estas elasticidades, também mostradas nas Figuras 5, 6 e 7, medem os efeitos de choques nas variáveis consideradas e levam em conta os efeitos simultâneos com as outras variáveis incluídas no modelo, ou seja, estas elasticidades de impulso relacionam o efeito contemporâneo completo (diferente do efeito parcial imediato dado em $\mathrm{A}_{0}$ ) de cada variável aos efeitos contemporâneos da variável que sofreu o choque não antecipado. Como se está interessado nos efeitos dos choques monetários e cambiais inesperados sobre o preço relativo agricultura-indústria, consideraram-se as elasticidades de impulso apenas sobre esta variável. 
Tabela 10 - Elasticidades de impulso sobre o preço relativo agricultura-indústria dos modelos VAR com 3 e 6 defasagens (variáveis em nível)

\begin{tabular}{l|ccc}
\hline Meses após o choque & \multicolumn{3}{c}{ 3 defasagens } \\
\cline { 2 - 4 } & TC & M1 & JN \\
\hline 01 & 0,3509 & 0,0046 & $-0,0025$ \\
02 & 0,5951 & 0,0608 & $-0,0153$ \\
03 & 0,3956 & 0,1305 & $-0,0446$ \\
06 & 0,2923 & 0,1170 & $-0,0723$ \\
12 & 0,1283 & 0,0459 & $-0,0359$ \\
18 & 0,0265 & 0,0232 & $-0,0123$ \\
24 & $-0,0097$ & 0,0149 & $-0,0005$ \\
\hline Meses após o choque & & 6 defasagens & \\
\cline { 2 - 4 } & TC & M1 & JN \\
\hline 01 & 0,7737 & $-0,0130$ & 0,0085 \\
02 & 0,9061 & 0,0366 & 0,0044 \\
03 & 0,7921 & 0,1265 & $-0,0244$ \\
06 & 0,4867 & 0,2783 & $-0,0373$ \\
12 & 0,2616 & 0,0392 & 0,0126 \\
18 & $-0,3833$ & 0,0617 & 0,0132 \\
24 & $-0,3410$ & 0,0227 & 0,0129 \\
\hline
\end{tabular}

Fonte: Dados da pesquisa.

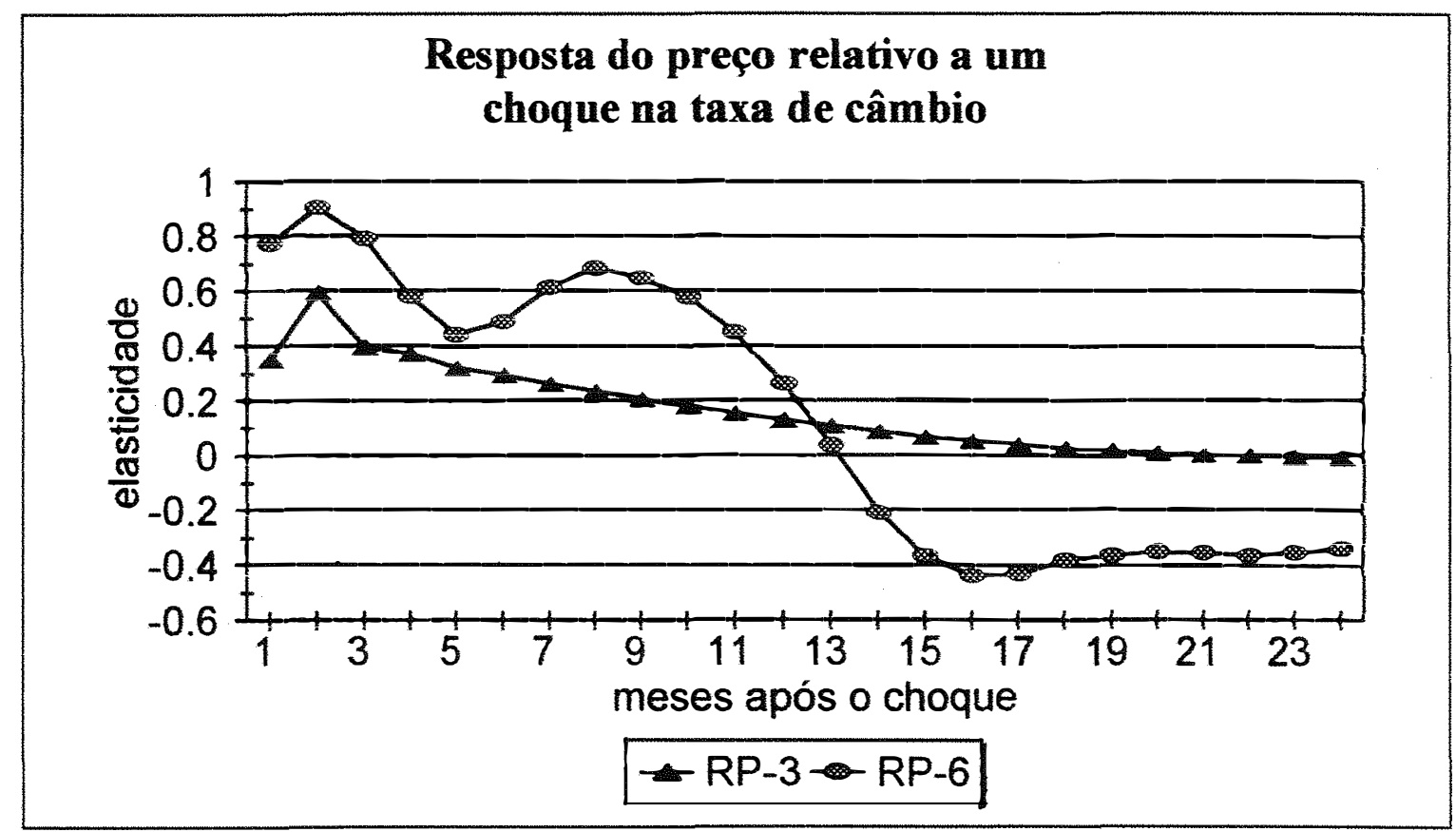

Figura 5 - Elasticidades de impulso da taxa de câmbio real sobre o preço relativo agricultura-indústria (modelos VAR em nível com 3 e 6 defasagens).

Fonte: Dados da pesquisa. 


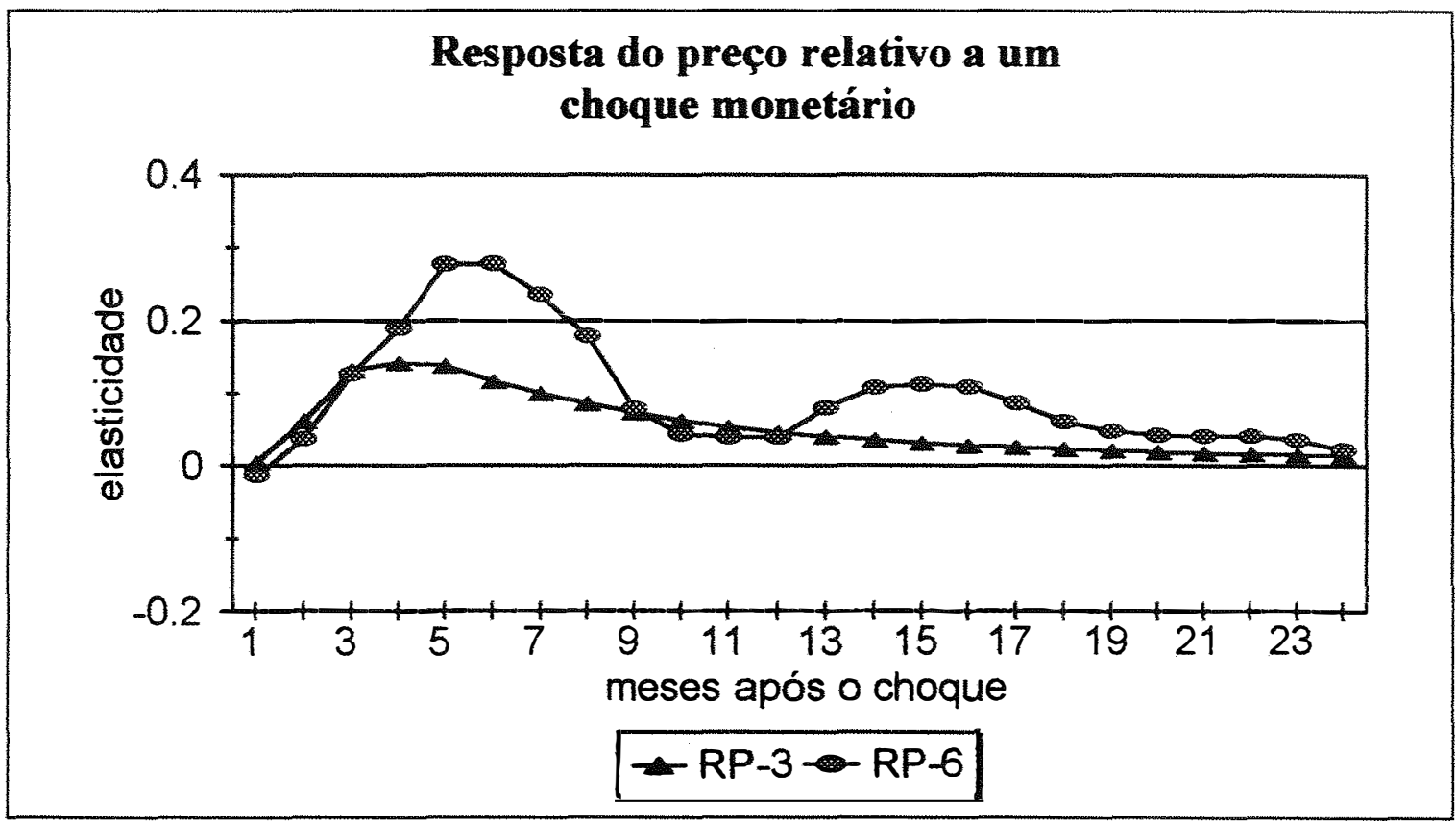

Figura 6 - Elasticidades de impulso da oferta monetária sobre o preço relativo agricultura-indústria (modelos VAR em nivel com 3 e 6 defasagens).

Fonte: Dados da pesquisa.

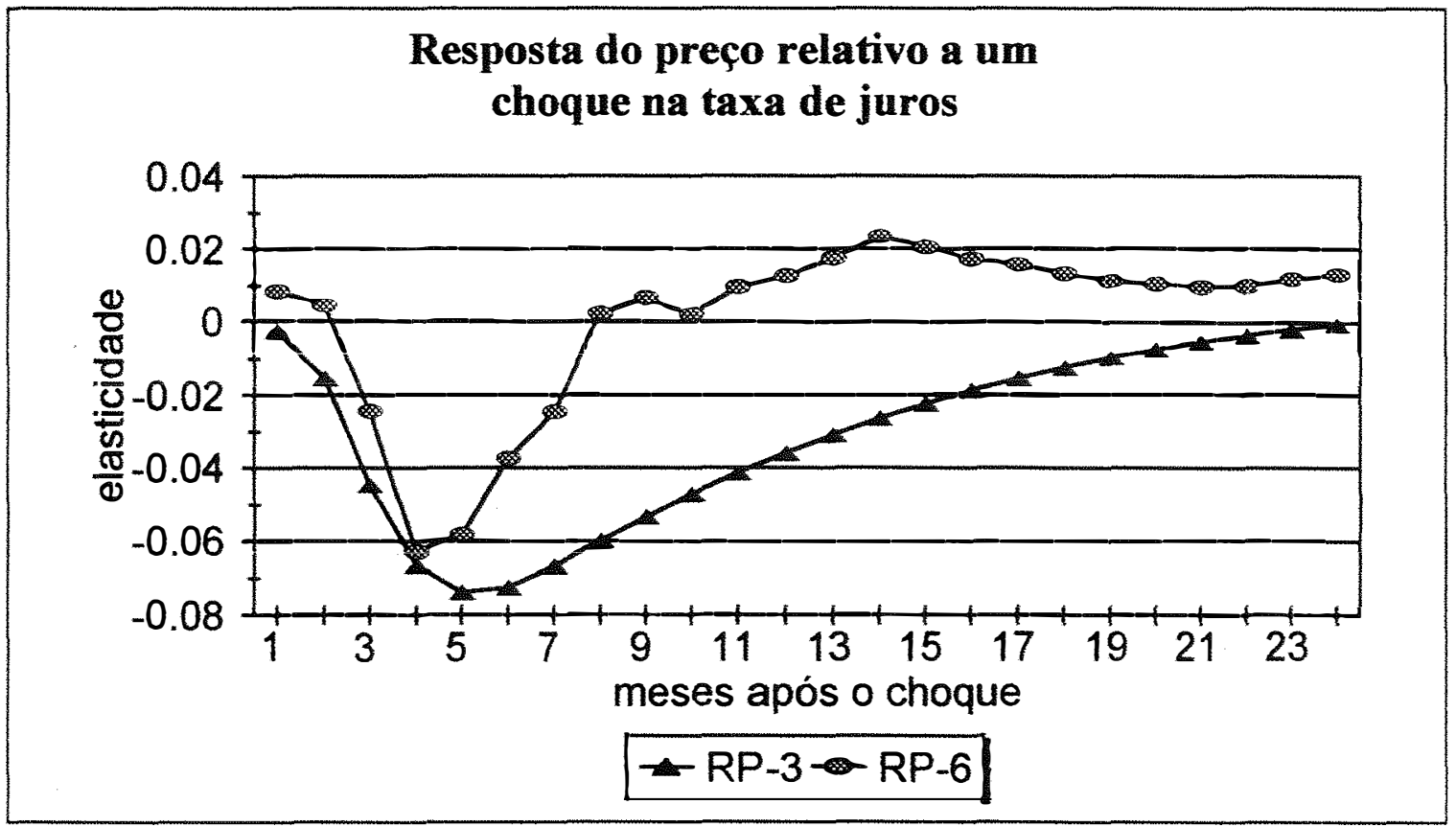

Figura 7 - Elasticidades de impulso da taxa nominal de juros sobre o preço relativo agricultura-indústria (modelos VAR em nível com 3 e 6 defasagens).

Fonte: Dados da pesquisa. 
Os resultados da tabela 10 podem ser interpretados com o auxilio das Figuras 5, 6 e 7. Nas figuras 5 e 6 estão as elasticidades de impulso de choques em TC e em M1, respectivamente, sobre o preço relativo agricultura-indústria; na Figura 7 tem-se a mesma coisa, só que os choques não esperados sobre o preço relativo provêm de aumentos na taxa nominal de juros. Da análise da tabela e das figuras citadas, verifica-se que os efeitos de choques na taxa de câmbio real sobre o preço relativo agriculturaindústria são mais significativos do que choques da mesma magnitude na oferta de moeda $^{25}$ ou na taxa nominal de juros independente do número de defasagens consideradas no modelo.

Os efeitos de choques (ver Tabela 10 ou Figuras 5,6 e 7) na oferta monetária ou na taxa nominal de juros praticamente não produzem nenhum efeito sobre o preço relativo agricultura-indústria no mês seguinte (na legenda das figuras, RP-3 refere-se ao modelo VAR com 3 defasagens e RP-6, ao modelo VAR com 6 defasagens), ao contrário dos choques na taxa de câmbio real. Os efeitos máximos dos choques monetários e na taxa nominal de juros tendem a ocorrer por volta do quarto/quinto mês e tornam-se menos intensos por volta do décimo segundo mês, enquanto o efeito máximo do choque cambial tende a ocorrer no segundo mês.

A resposta do preço relativo agricultura-indústria aos choques cambiais e monetários no modelo VAR com 6 defasagens mostra-se um pouco oscilatória, mas tende a acompanhar, de modo geral, a trajetória de resposta do modelo VAR com 3 defasagens. Os choques monetários e cambiais tendem a favorecer o setor agrícola, ou seja, as relações de troca melhoram em favor deste setor pelo menos no primeiro ano após esses choques. Por outro lado, os choques (aumentos) na taxa nominal de juros tendem a favorecer o setor industrial nos primeiros oito meses no modelo VAR com 6 defasagens, quando, então, as relações de.troca se invertem. No caso do modelo VAR com 3 defasagens, os choques na taxa de juros tendem a favorecer o setor industrial até

\footnotetext{
${ }^{25}$ Vale observar que esses resultados (casos dos choques monetários e cambiais) são consistentes com os resultados encontrados por BURNQUIST \& KYLE (1992) e BARROS (1992).
} 
aproximadamente o vigésimo mês, ocasião em que os efeitos desses choques tendem a desaparecer.

Na Tabela 11 apresentam-se as decomposições da variância dos erros de previsão do preço relativo agricultura-indústria (em percentagem) dos modelos VAR com 3 e 6 defasagens (variáveis em nível). Como se pode observar, o preço relativo agricultura-indústria tem sua variância de previsão explicada em grande parte por choques nele mesmo. No primeiro ano, por exemplo, a participação do preço relativo agricultura-indústria na explicação de sua própria variância de previsão é superior a $66 \%$ no modelo VAR com 3 defasagens, enquanto no modelo VAR com 6 defasagens essa explicação cai para $49,53 \%$ no décimo segundo mês. A partir do primeiro ano aumenta a importância relativa das outras variáveis na explicação da variância de previsão dessa variável.

Tabela 11 - Decomposição da variância de previsão do preço relativo agriculturaindústria, em percentagem (modelo VAR em nível com 3 e 6 defasagens)

\begin{tabular}{l|cccc}
\hline \multirow{2}{*}{ Meses } & \multicolumn{4}{|c}{ 3 defasagens } \\
\cline { 2 - 5 } & TC & M1 & JN & RP \\
\hline 01 & 5,95 & 0,01 & 0,02 & 94,02 \\
02 & 11,13 & 0,74 & 0,42 & 87,71 \\
03 & 9,85 & 2,76 & 2,62 & 84,77 \\
06 & 8,66 & 5,69 & 11,84 & 73,81 \\
12 & 8,71 & 6,56 & 18,42 & 66,31 \\
18 & 8,70 & 6,76 & 19,53 & 65,01 \\
24 & 8,68 & 6,86 & 19,58 & 64,88 \\
\hline Meses & \multicolumn{5}{|c}{} & \\
& TC & 6 defasagens & JN & RP \\
\hline 01 & 20,62 & 0,06 & 0,21 & 79,11 \\
02 & 26,87 & 0,31 & 0,15 & 72,67 \\
03 & 25,75 & 2,35 & 0,73 & 71,17 \\
06 & 21,82 & 17,20 & 6,15 & 54,83 \\
12 & 26,75 & 18,74 & 4,98 & 49,53 \\
18 & 27,41 & 19,62 & 5,30 & 47,67 \\
24 & 29,78 & 19,16 & 5,34 & 45,72 \\
\hline
\end{tabular}

Fonte: Dados da pesquisa. 
$\mathrm{Na}$ seção seguinte procede-se a essa mesma análise, só que o modelo VAR é especificado na forma de um MCE. Os testes de raiz unitária e co-integração permitem, respectivamente, que se considerem as séries utilizadas como sendo integradas de ordem um e que existe relação de co-integração entre elas.

\subsubsection{Modelo de correção de erro (MCE)}

Antes da apresentação e análise dos resultados do MCE relativos à matriz de interações contemporâneas, elasticidades de impulso e decomposição da variância de previsão do preço relativo agricultura-indústria, mostram-se os resultados obtidos nos testes de raiz unitária e co-integração.

Os critérios de SCHWARZ e de informação de AKAIKE (AIC) indicaram como melhor especificação (defasagens): 2 defasagens (AIC e SC) para a série TC; 4 (AIC e SC) defasagens para a série M1; 1 (SC) ou 2 defasagens (AIC) para a série JN; e 1 (SC) ou 7 (AIC) defasagens para a série RP. Os testes para constante e tendência (estatísticas $\tau_{\alpha \mu}, \tau_{\alpha \tau}$ e $\tau_{\beta \tau}$; e $\Phi_{1}, \Phi_{2}$ e $\Phi_{3}$ ) indicaram: constante para a série TC (o teste $\Phi_{2}$ foi rejeitado a $5 \%$ de probabilidade); ausência de constante e tendência para a série M1; ausência de constante e tendência para a série JN; apenas constante para a série RP (1 defasagem); e ausência de constante e tendência para essa série quando se consideram 7 defasagens.

Os resultados dos testes para raiz unitária (ver Tabelas 12 e 13) dependem do nível de significância e número de defasagens considerados. Caso se escolha um nível de significância de $1 \%$, todas as variáveis consideradas são integradas de ordem um, ou seja, $I(1)$, pelo teste de PHILLIPS-PERRON. As séries M1 e RP (7 defasagens) são integradas de ordem dois pelo teste de DICKEY-FULLER (aceitam-se as hipóteses nulas nas equações (45) e (46) e rejeita-se a hipótese nula para $I(3)$ - resultado não mostrado na Tabela 12). No caso da série M1, quando o teste de raiz unitária é feito sem 
constante e sem tendência, o t calculado é positivo, o que é pouco plausivel. Preferiu-se considerar esta série com constante e tendência, dada a evidência mostrada pela Figura 4 (capítulo 2) de uma tendência nos dados quando tomados nos logaritmos. ${ }^{26}$

Tabela 12 - Teste DICKEY-FULLER para não-estacionariedade

\begin{tabular}{l|cccc}
\hline \multirow{2}{*}{ Variáveis } & \multicolumn{3}{c}{ Equação (45) } & $\begin{array}{c}\text { Hipótese } \\
\text { nula }\end{array}$ \\
\cline { 2 - 5 } & Constante & Tendência & Defasagens $(p)$ \\
\hline TC & $\mathrm{x}$ & & 2 & $-2,9930^{*}$ \\
M1 & $\mathrm{x}$ & $\mathrm{x}$ & 4 & $-1,9316$ \\
JN & & & 1 & $-0,1762$ \\
& & & 2 & $-0,3512$ \\
RP & $\mathrm{x}$ & & 1 & $-2,9428^{*}$ \\
& $\mathrm{x}$ & & 7 & $-2,3629$ \\
\hline Variáveis & & Equação (46) & & Hipótese \\
& & & & nula \\
\cline { 2 - 6 } & Constante & Tendência & Defasagens $(p)$ & \\
\hline TC & $\mathrm{x}$ & & 2 & $-5,2516^{* *}$ \\
M1 & $\mathrm{x}$ & $\mathrm{x}$ & 4 & $-2,4470$ \\
JN & & & 1 & $-7,4765^{* *}$ \\
& & & 2 & $-6,2584^{* *}$ \\
RP & $\mathrm{x}$ & & 1 & $-6,8423^{* *}$ \\
& $\mathrm{x}$ & & 7 & $-2,6385$ \\
\hline
\end{tabular}

Fonte: Dados da pesquisa.

* Significativo a $5 \%$ de probabilidade.

** Significativo a $1 \%$ de probabilidade.

Nota: Os valores críticos e estatísticas relevantes estão no Apêndice 2.

Na Tabela 14 mostram-se os resultados do teste JOHANSEN-JUSELIUS para co-integração do modelo VAR com 3 defasagens (ou seja, aceitou-se que as séries de dados utilizadas nesta pesquisa são integradas de ordem um). Verifica-se que tanto pela estatística autovalor máximo quanto pela estatística traço rejeita-se a hipótese nula

\footnotetext{
${ }^{26}$ Note-se que, no teste PHILLIPS-PERRON, considerou-se uma constante na equação para a série JN. Isso foi feito porque utilizou-se para este teste um pacote que só admitia as possibilidades: com constante ou com constante e tendência. Caso se utilize também uma constante no teste DICKEY-FULLER, o resultado é o mesmo, ou seja. obtém-se que a série $\mathrm{JN}$ é integrada de ordem um. ou seja, integrada nas primeiras diferenças.
} 
$r=0$ e aceita-se que $r \leq 1$, a $95 \%$ de probabilidade, podendo-se concluir que há uma relação de co-integração ou relação estável de longo prazo ligando as quatro séries. Neste caso, existem três $(k-r)$ fontes de não-estacionariedade.

Tabela 13 - Teste PHILLIPS-PERRON para não-estacionariedade

\begin{tabular}{|c|c|c|c|}
\hline \multirow[t]{2}{*}{ Variáveis } & \multirow[t]{2}{*}{ Defasagens $(p)$} & \multicolumn{2}{|c|}{ Série em nível } \\
\hline & & Com constante & Com constante e tendência \\
\hline TC & 2 & $-2,8883$ & - \\
\hline M1 & 4 & - & $-1,4620$ \\
\hline \multirow[t]{2}{*}{$\mathrm{JN}$} & 1 & $-2,0084$ & - \\
\hline & 2 & $-2,2011$ & - \\
\hline \multirow[t]{2}{*}{$\mathrm{RP}$} & 1 & $-2,9834^{*}$ & - \\
\hline & 7 & $-2,9735^{*}$ & - \\
\hline \multirow[t]{2}{*}{ Variáveis } & \multirow[t]{2}{*}{ Defasagens $(p)$} & \multicolumn{2}{|c|}{ Série nas primeiras diferenças } \\
\hline & & Com constante & Com constante e tendência \\
\hline $\mathrm{TC}$ & 2 & $-6,4787 * *$ & - \\
\hline M1 & 4 & - & $-7,7658 * *$ \\
\hline \multirow[t]{2}{*}{$\mathrm{JN}$} & 1 & $-7,5433 * *$ & - \\
\hline & 2 & $-7,5505 * *$ & - \\
\hline \multirow[t]{2}{*}{ RP } & 1 & $-6,9380 * *$ & - \\
\hline & 7 & $-6,8320 * *$ & - \\
\hline
\end{tabular}

Fonte: Dados da pesquisa.

* Significativo a $5 \%$ de probabilidade.

** Significativo a $1 \%$ de probabilidade.

Nota: Os valores críticos e estatísticas relevantes estão no Apêndice 2.

Tabela 14 - Teste JOHANSEN-JUSELIUS para co-integração (VAR com 3 defasagens)

\begin{tabular}{|c|c|c|c|c|}
\hline \multirow[t]{2}{*}{ Hipótese nula } & \multicolumn{2}{|c|}{ Autovalor máximo } & \multicolumn{2}{|c|}{ Estatística traço } \\
\hline & valor observado & $\begin{array}{c}\text { valor crítico } \\
95 \%\end{array}$ & valor observado & $\begin{array}{c}\text { valor crítico } \\
95 \%\end{array}$ \\
\hline$r \leq 3$ & 4,98 & 9,09 & 4,98 & 9,09 \\
\hline$r \leq 2$ & 6,57 & 15,75 & 11,55 & 20,17 \\
\hline$r \leq 1$ & 16,35 & 21,89 & 27,90 & 35,07 \\
\hline$r=0$ & 36,45 & 28,17 & 64,35 & 53,35 \\
\hline
\end{tabular}

Fonte: Dados da pesquisa.

Nota:Os valores criticos foram tirados da Tabela A3 (JOHANSEN \& JUSELIUS, 1990). 
Essa relação de co-integração (VAR com 3 defasagens) é dada pela seguinte expressão (primeira coluna da matriz $\beta$ estimada, ver equação 48 ):

$$
\mathrm{z}_{13}=\mathrm{TC}-0,059 \mathrm{M} 1-0,015 \mathrm{JN}-0,219 \mathrm{RP}-3,828
$$

Na Tabela 15 mostram-se os resultados do teste JOHANSEN-JUSELIUS para co-integração (VAR com 6 defasagens). Verifica-se que pela estatística autovalor máximo rejeita-se a hipótese nula $r \leq 1$ e aceita-se que $r \leq 2$, ou seja, há duas relações de co-integração ou relações estáveis de longo prazo ligando as quatro séries. Por outro lado, se a estatística relevante é o traço, rejeita-se a hipótese nula $r \leq 2$ e aceita-se que $r \leq 3$, ou seja, há três e não duas relações estáveis de longo prazo ligando as quatro séries consideradas. Neste caso, existe apenas uma $(k-r)$ fonte de nãoestacionariedade.

Tabela 15 - Teste JOHANSEN-JUSELIUS para co-integração (VAR com 6 defasagens)

\begin{tabular}{l|cc|cc}
\hline \multirow{2}{*}{ Hipótese nula } & \multicolumn{2}{|c|}{ Autovalor máximo } & \multicolumn{2}{|c}{ Estatística traço } \\
\cline { 2 - 5 } & valor observado & $\begin{array}{c}\text { valor crítico } \\
95 \%\end{array}$ & valor observado & $\begin{array}{c}\text { valor crítico } \\
\end{array}$ \\
\hline$r \leq 3$ & 6,35 & 9,09 & 6,35 & $95 \%$ \\
$r \leq 2$ & 15,18 & 15,75 & 21,53 & 20,17 \\
$r \leq 1$ & 31,20 & 21,89 & 52,73 & 35,07 \\
$r=0$ & 65,60 & 28,17 & 118,33 & 53,35 \\
\hline
\end{tabular}

Fonte: Dados da pesquisa.

Nota: Os valores criticos foram tirados da tabela A3 (JOHANSEN \& JUSELIUS, 1990).

Aceitando-se a hipótese alternativa de que há três relações de cointegração (VAR com 6 defasagens), estas são dadas pelas seguintes expressões (três primeiras colunas da matriz $\beta$ estimada):

$$
\begin{aligned}
& \mathrm{z}_{16}=\mathrm{TC}-0,055 \mathrm{M} 1-0,114 \mathrm{JN}-0,569 \mathrm{RP}-1,920 \\
& \mathrm{z}_{26}=-24,737 \mathrm{TC}+\mathrm{M} 1-3,091 \mathrm{JN}+9,497 \mathrm{RP}+80,537 \\
& \mathrm{z}_{36}=3,842 \mathrm{TC}-0,493 \mathrm{M} 1+\mathrm{JN}+5,451 \mathrm{RP}-46,532
\end{aligned}
$$


Dados os resultados obtidos nos testes de raiz unitária e co-integração, estimaram-se modelos de correção de erro com 3 e 6 defasagens com as variáveis nas primeiras diferenças, e como termo(s) de correção de erro foram utilizadas a expressão (57) com uma defasagem (ver equação 48) para o MCE com 3 defasagens e as expressões de (58) a (60) também com uma defasagem para o MCE com 6 defasagens. Para diferenciar as variáveis nas primeiras diferenças das variáveis em nível, acrescentouse um D (de diferença) antes da denominação de cada variável. Dessa forma, M1, por exemplo, passa a ser denominada nas primeiras diferenças por DM1, JN por DJN, e assim por diante.

Utilizou-se, nos modelos de correção de erro, a mesma identificação das matrizes de interações contemporâneas $\mathrm{A}_{0}$ dos modelos $\mathrm{VAR}$ com as variáveis em nível. Esses modelos (de correção de erro) foram estimados com 3 defasagens ( 2 defasagens com as variáveis nas primeiras diferenças mais o termo de correção de erro com 1 defasagem) e com 6 defasagens ( 5 defasagens com as variáveis nas primeiras diferenças mais os termos de correção de erro com 1 defasagem). Convém observar que se está estimando os modelos em nível com uma constante e os modelos nas diferenças sem drift.

$\mathrm{Na}$ Tabela 16 mostram-se os coeficientes estimados das matrizes de interações contemporâneas $A_{0}$ dos modelos de correção de erro com 3 e 6 defasagens. Os respectivos desvios-padrões estimados de cada coeficiente dessas matrizes (modelos em nivel ou nas primeiras diferenças) são muito semelhantes (comparar as Tabelas $9 \mathrm{e}$ 16). Novamente, como nos modelos em nível, apenas o coeficiente relacionado com o estoque nominal de moeda (no caso, agora, DM1), na equação da taxa nominal de juros (DJN), e o coeficiente da taxa de câmbio real (DTC), na equação do preço relativo agricultura-indústria (DRP), foram estatisticamente significativos a $5 \%$ de probabilidade. No caso dos demais coeficientes (estatisticamente não-significativos), também como no caso dos modelos em nível, há diferenças quando se consideram 3 ou 6 defasagens. 
Tabela 16 - Matrizes de interações contemporâneas $\left(A_{0}\right)$ dos modelos de correção de erro com 3 e 6 defasagens (variáveis nas primeiras diferenças)*

\begin{tabular}{l|cccc}
\hline Equações & \multicolumn{4}{|c}{ Variáveis } \\
\cline { 2 - 5 } (3 defasaglicativas \\
\hline DTC & DTC & DM1 & DJN & DRP \\
\hline
\end{tabular}

\begin{tabular}{|c|c|c|c|c|}
\hline DM1 & $\begin{array}{c}0,1692 \\
(0,3367)\end{array}$ & 1 & & \\
\hline DJN & & $\begin{array}{c}1,8951 \\
(0,3458)\end{array}$ & 1 & \\
\hline DRP & $\begin{array}{l}-0,4139 \\
(0,1704) \\
\end{array}$ & & $\begin{array}{l}-0,0038 \\
(0,0170) \\
\end{array}$ & 1 \\
\hline \multirow{2}{*}{$\begin{array}{l}\text { Equações } \\
\text { ( } 6 \text { defasagens) }\end{array}$} & \multicolumn{4}{|c|}{ Variáveis Explicativas } \\
\hline & DTC & DM1 & DJN & DRP \\
\hline DTC & 1 & & & \\
\hline DM1 & $\begin{array}{l}-0,1394 \\
(0,3880)\end{array}$ & 1 & & \\
\hline DJN & & $\begin{array}{c}1,7202 \\
(0,3383)\end{array}$ & 1 & \\
\hline DRP & $\begin{array}{c}-0,6754 \\
(0,1910)\end{array}$ & & $\begin{array}{c}0,0102 \\
(0,0180)\end{array}$ & 1 \\
\hline
\end{tabular}

Fonte: Dados de pesquisa.

Nota: $(*)$ Entre parênteses estão as estimativas do desvio-padrão de cada coeficiente.

No modelo de correção de erro com 3 defasagens, uma desvalorização real inesperada da taxa de câmbio (primeiras diferenças) reduz o estoque de moeda (DM1), enquanto que, quando se consideram 6 defasagens nesse modelo, o efeito obtido é inverso. Essa inversão de sinais também ocorre quando se consideram os efeitos de aumentos na taxa nominal de juros (DJN) sobre o preço relativo agricultura-indústria (DRP). Convém observar que não foi possível estabelecer inequivocamente no modelo teórico (ver capítulo 3) o efeito completo de uma desvalorização cambial sobre o preço relativo agricultura-indústria, embora teoricamente se tenha estabelecido que o aumento da taxa de juros deprimiria os preços agrícolas relativos aos preços industriais. Entretanto, deve-se notar que os efeitos medidos em $\mathrm{A}_{0}$ são apenas imediatos e parciais e 
que essa inversão de sinais entre os resultados de diferentes modelos ocorreram apenas nos casos de coeficientes estatisticamente não-significativos.

A interpretação dos resultados apresentados na Tabela 16 é feita da mesma forma do caso da Tabela 8; a única diferença é que, no caso da Tabela 16, tem-se que lembrar que as variáveis estão nas primeiras diferenças. Assim, por exemplo, os efeitos imediatos e parciais de um aumento inesperado de $10 \%$ (desvalorização) na taxa de câmbio real (DTC) são o aumento de 1,39\% em DM1 e o aumento de 6,75\% no preço relativo agricultura-indústria (DRP) (MCE com 6 defasagens). Também, como no caso dos modelos em nível, o impacto contemporâneo mais significativo foi o da expansão não esperada de DM1 sobre DJN, independente do número de defasagens consideradas.

$\mathrm{Na}$ Tabela 17 mostram-se as elasticidades de impulso das outras variáveis do sistema sobre o preço relativo agricultura-indústria (DRP) (modelos de correção de erro com 3 e 6 defasagens). Os resultados apresentados nesta tabela podem ser interpretados com auxílio das Figuras 8, 9 e 10. Na Figura 8 medem-se as elasticidades de impulso de choques em DTC sobre DRP; nas Figuras 9 e 10 tem-se a mesma coisa, só que os choques são originários de DM1 e DJN, respectivamente. Da análise da tabela e das figuras citadas, verifica-se, como no caso dos modelos em nível, que os efeitos de choques em DTC sobre DRP são mais significativos do que se esses choques sobre esse preço fossem provenientes de DM1 ou DJN, independente do número de defasagens consideradas. 
Tabela 17 - Elasticidades de impulso sobre o preço relativo agricultura-indústria dos modelos de correção de erro com 3 e 6 defasagens (variáveis nas primeiras diferenças)

\begin{tabular}{l|ccc}
\hline Meses após o choque & \multicolumn{3}{c}{3 defasagens } \\
\cline { 2 - 4 } & DTC & DM1 & DNN \\
\hline 01 & 0,4151 & $-0,0072$ & 0,0038 \\
02 & 0,3658 & 0,0273 & $-0,0041$ \\
03 & $-0,0060$ & 0,0466 & $-0,0229$ \\
06 & $-0,0063$ & $-0,0013$ & 0,0005 \\
12 & $-0,0001$ & 0,0000 & 0,0000 \\
18 & 0,0000 & 0,0000 & 0,0000 \\
24 & 0,0000 & 0,0000 & 0,0000 \\
\hline Meses após o choque & \multicolumn{3}{|c}{} \\
\cline { 2 - 4 } & DTC & D defasagens & \\
\hline 01 & 0,6779 & 0,0175 & $-0,0102$ \\
02 & 0,2506 & $-0,0149$ & 0,0316 \\
03 & $-0,0427$ & 0,0257 & 0,0117 \\
06 & $-0,0614$ & $-0,0438$ & 0,0250 \\
12 & $-0,0986$ & $-0,0110$ & 0,0118 \\
18 & $-0,0747$ & $-0,0359$ & 0,0104 \\
24 & $-0,1085$ & $-0,0373$ & 0,0150 \\
\hline
\end{tabular}

Fonte: Dados da pesquisa.

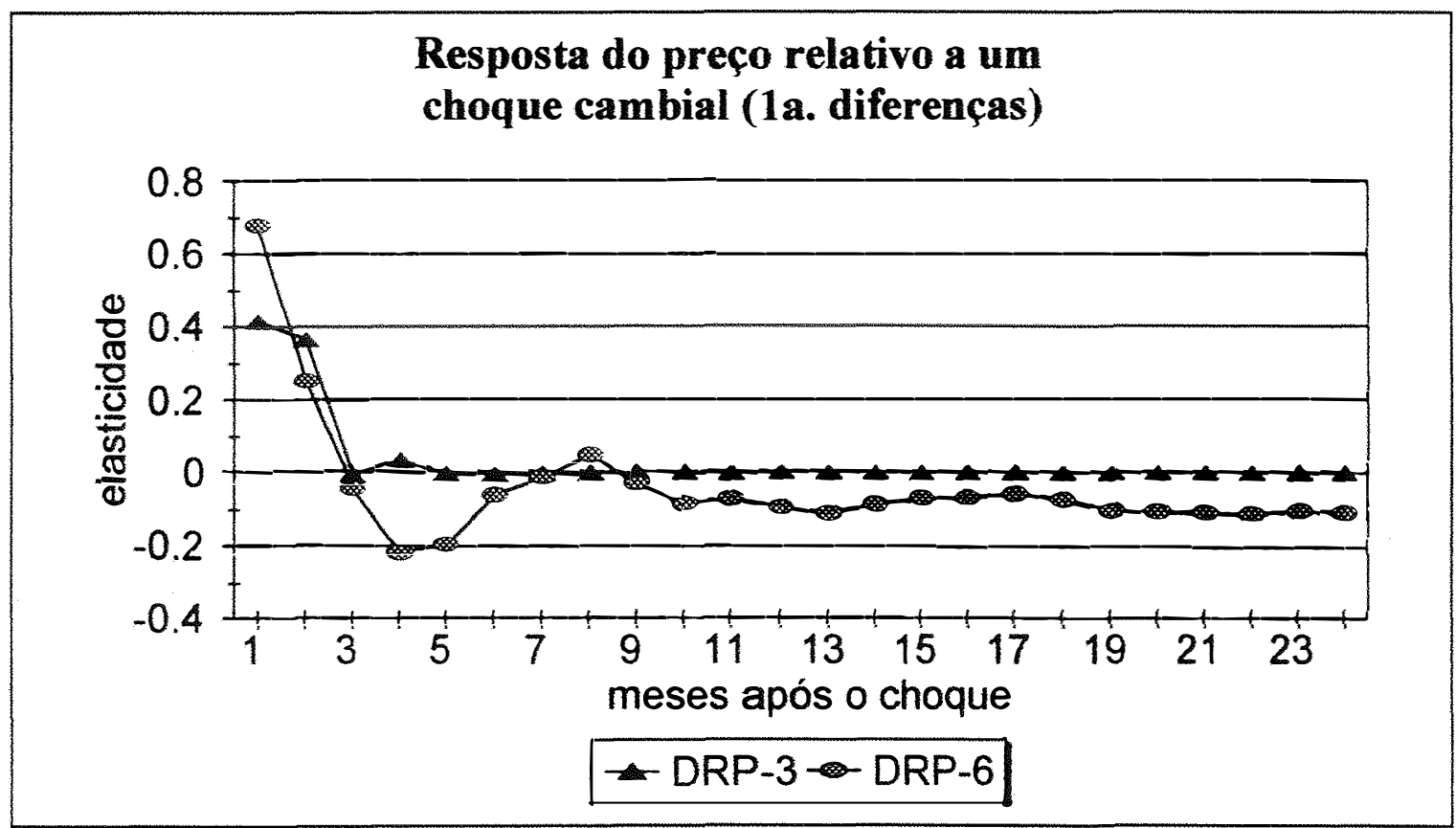

Figura 8 - Elasticidades de impulso da taxa de câmbio real sobre o preço relativo agricultura-indústria dos modelos de correção de erro com 3 e 6 defasagens.

Fonte: Dados da pesquisa. 


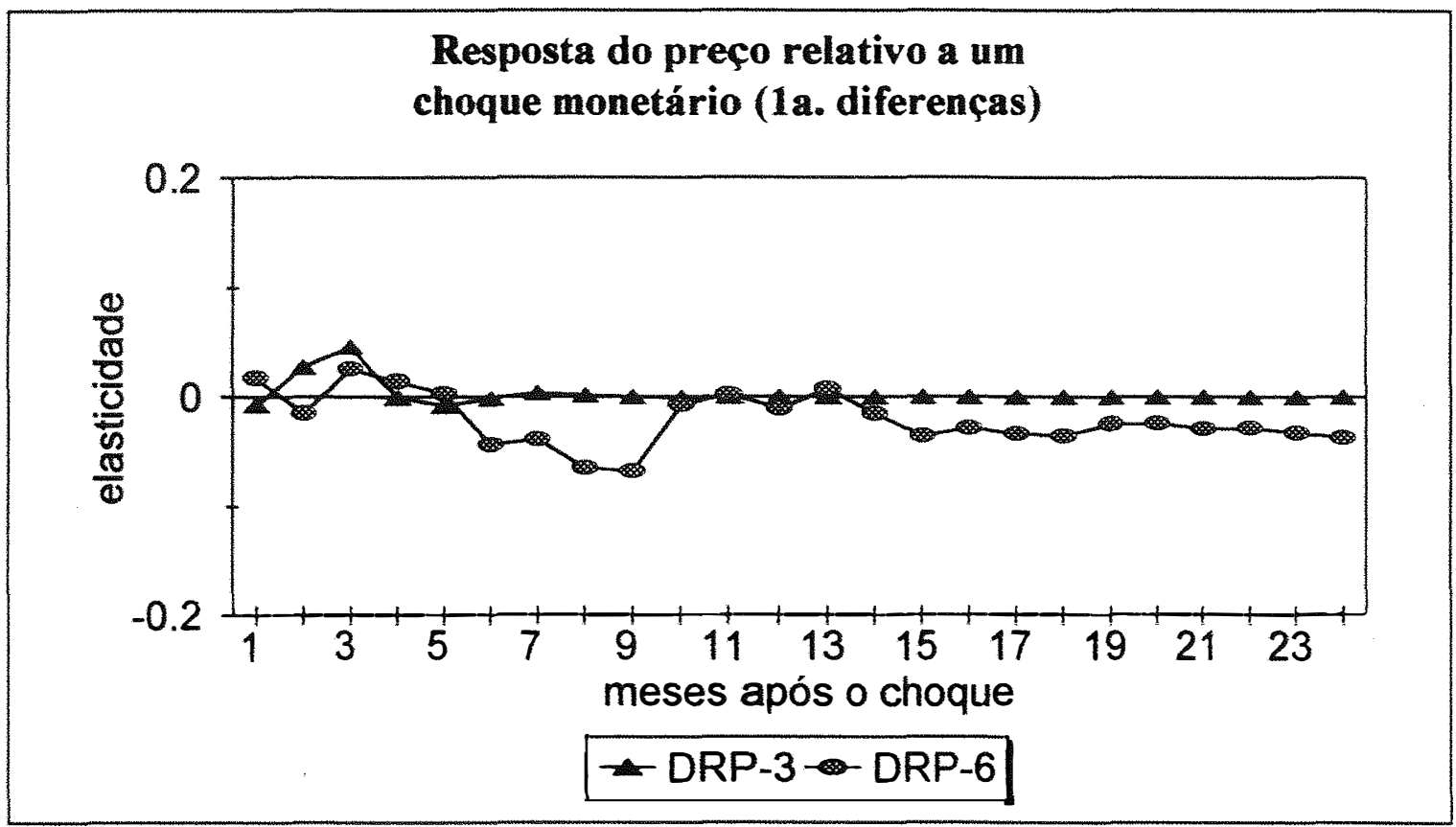

Figura 9 - Elasticidades de impulso da oferta monetária sobre o preço relativo agricultura-indústria dos modelos de correção de erro com 3 e 6 defasagens.

Fonte: Dados da pesquisa.

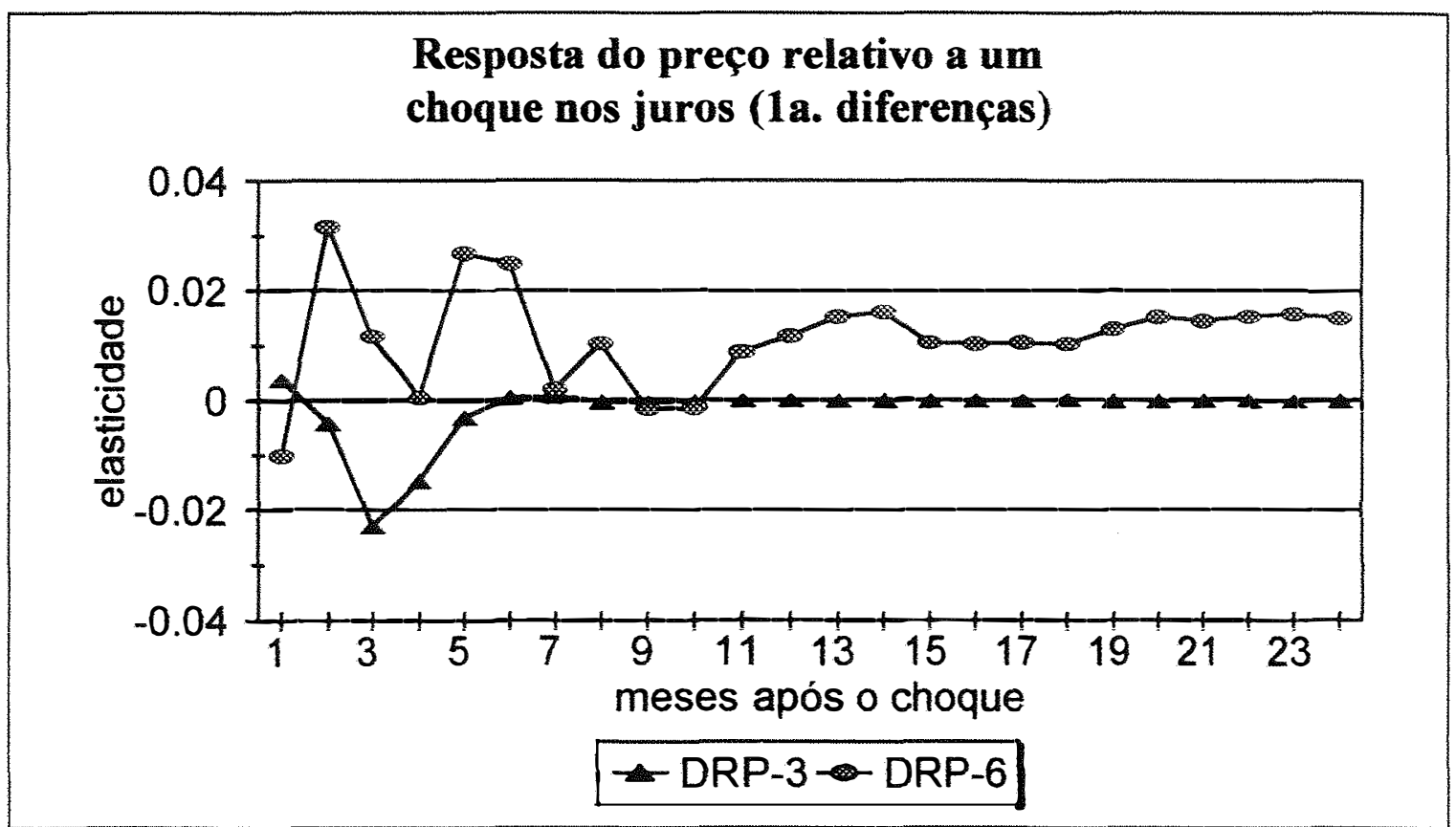

Figura 10 - Elasticidades de impulso da taxa nominal de juros sobre o preço relativo agricultura-indústria dos modelos de correção de erro com 3 e 6 defasagens.

Fonte: Dados da pesquisa. 
Os efeitos de choques em DM1 ou DJN sobre DRP, como no caso dos modelos em nível, foram bastante reduzidos no mês seguinte após o choque. Os impactos desses choques sobre o preço relativo agricultura-indústria (DRP) foram menos reduzidos quando comparados aos modelos em nível (ver Tabelas 10 e 17) e os ajustamentos, em geral, foram mais rápidos no MCE com 3 defasagens. Os efeitos de choques nas outras variáveis sobre DRP neste modelo tendem a desaparecer por volta do sexto mês. No caso do MCE com 6 defasagens, as trajetórias que medem os efeitos de choques em DTC, DM1 e DJN sobre DRP apresentam um comportamento oscilatório; apenas no caso dos efeitos de choques em DTC sobre DRP, as trajetórias das elasticidades de impulso nos modelos com 3 e 6 defasagens foram mais parecidas.

Na Tabela 18 mostram-se as decomposições da variância dos erros de previsão do preço relativo agricultura-indústria dos modelos de correção de erro com $3 \mathrm{e}$ 6 defasagens, em percentagem (variáveis nas primeiras diferenças). Esses resultados, quando comparados aos modelos em nível (ver Tabela 10), mostram que o preço relativo agricultura-indústria nas primeiras diferenças é mais fortemente exógeno. Mais de $84 \%$ da variância de previsão do preço relativo agricultura-indústria (MCE com 3 defasagens) é explicada por choques inesperados nele mesmo, nos primeiros dois anos após o choque. No caso do MCE com 6 defasagens, este percentual é um pouco menor, ou seja, mais de $67 \%$ da variância de previsão do preço relativo é explicada por choques inesperados nele mesmo. 
Tabela 18 - Decomposição da variância de previsão do preço relativo agriculturaindústria, em percentagem (MCE com 3 e 6 defasagens - variáveis nas primeiras diferenças).

\begin{tabular}{l|cccc}
\hline \multirow{2}{*}{ Meses } & \multicolumn{4}{c}{ 3 defasagens } \\
\cline { 2 - 5 } & DTC & DM1 & DJN & DRP \\
\hline 01 & 7,95 & 0,02 & 0,05 & 91,98 \\
02 & 13,10 & 0,28 & 0,09 & 86,53 \\
03 & 12,65 & 1,00 & 1,62 & 84,73 \\
06 & 12,57 & 1,01 & 2,25 & 84,17 \\
12 & 12,57 & 1,01 & 2,25 & 84,17 \\
18 & 12,57 & 1,01 & 2,25 & 84,17 \\
24 & 12,57 & 1,01 & 2,25 & 84,17 \\
\hline Meses & \multicolumn{3}{c}{} \\
\cline { 2 - 5 } & DTC & 6 defasagens & \\
\hline 01 & 16,71 & DM1 & DJN & DRP \\
02 & 17,89 & 0,11 & 0,31 & 82,87 \\
03 & 16,55 & 0,19 & 3,11 & 78,81 \\
06 & 17,28 & 0,39 & 3,22 & 79,84 \\
12 & 16,89 & 0,97 & 5,97 & 75,78 \\
18 & 17,00 & 3,77 & 6,32 & 73,02 \\
24 & 17,40 & 4,81 & 7,90 & 70,29 \\
\hline
\end{tabular}

Fonte: Dados de pesquisa.

\subsubsection{Modelo VAR em nível e MCE - taxa de juros exógena}

Nesta seção estende-se a análise de auto-regressão vetorial, para considerar uma nova disposição das variáveis na matriz de interações contemporâneas. A idéia é colocar a taxa de juros numa posição mais exógena nessa matriz e alterar 0 sentido de causalidade entre as variáveis. Em termos práticos, a nova disposição das variáveis refletiria o fato de as autoridades monetárias estarem controlando a taxa nominal de juros em vez do estoque nominal de moeda. É importante destacar que todas as variáveis num modelo VAR são consideradas endógenas e podem sofrer choques. Essas restrições que estão sendo introduzidas limitam-se à matriz de interações contemporâneas. 
Nessa nova identificação da matriz de interações contemporâneas, as variáveis foram ordenadas da seguinte forma: TC foi considerada mais exógena em relação às demais e aparece na posição $(1,1)$; logo em seguida, também numa posição exógena $(2,2)$, vem a variável JN; M1 aparece na posição $(3,3)$, mas é influenciada por TC e JN; assim, nas posições $(3,1)$ e $(3,2)$ devem aparecer coeficientes diferentes de zero; RP foi colocada na posição $(4,4)$, sendo influenciada pelas variáveis TC e JN, cujos efeitos serão captados nas posições $(4,1)$ e $(4,2)$, respectivamente.

Utilizaram-se as mesmas especificações (3 e 6 defasagens) na estimação tanto do modelo VAR em nível quanto do MCE. Serão apresentados a seguir apenas os resultados do modelo VAR em nível com 3 defasagens e do MCE com 6 defasagens, pois nos demais casos (VAR em nivel com 6 defasagens e MCE com 3 defasagens) não houve convergência quando de sua estimação utilizando o procedimento de BERNANKE, mesmo sendo permitido um número elevado de interações. $\mathrm{O}$ modelo VAR em nível foi estimado com constante e o MCE, sem drift.

$\mathrm{Na}$ Tabela 19 apresentam-se os coeficientes estimados da matriz $\mathrm{A}_{0}$ do modelo VAR em nível com 3 defasagens. Vale lembrar que os valores colocados fora da diagonal principal devem ter seus sinais trocados para que se possa interpretar corretamente os efeitos contemporâneos, ou seja, os efeitos parciais imediatos da variável que sofre o choque em cada coluna sobre a variável que lhe é contemporaneamente relacionada em cada linha. Apenas dois dos coeficientes estimados foram estatisticamente significativos a $5 \%$ de probabilidade: o coeficiente de JN (coluna 2), na equação de M1 (linha 3), e o coeficiente de TC (coluna 1), na equação de RP(linha 4). 
Tabela 19 - Matriz de interações contemporâneas $\left(\mathrm{A}_{0}\right)$ do modelo VAR em nível com 3 defasagens - taxa de juros exógena*

\begin{tabular}{|c|c|c|c|c|}
\hline \multirow{2}{*}{ Equações } & \multicolumn{4}{|c|}{ Variáveis Explicativas } \\
\hline & $\mathrm{TC}$ & $\mathrm{JN}$ & M1 & $\mathrm{RP}$ \\
\hline TC & 1 & & & \\
\hline JN & & 1 & & \\
\hline M1 & $\begin{array}{c}0,4006 \\
(0,3034)\end{array}$ & $\begin{array}{c}0,1597 \\
(0,0299)\end{array}$ & 1 & \\
\hline $\mathrm{RP}$ & $\begin{array}{c}-0,3507 \\
(0,1711)\end{array}$ & $\begin{array}{c}0,0025 \\
(0,0168)\end{array}$ & & 1 \\
\hline
\end{tabular}

Fonte: Dados da pesquisa.

Nota: Entre parênteses estão as estimativas do desvio-padrão de cada coeficiente.

Verifica-se, na Tabela 19, que desvalorizações reais da taxa de câmbio reduzem o estoque nominal de moeda e aumentam o preço relativo agricultura-indústria. Esse efeito sobre o preço relativo é esperado, caso se admita que os preços agrícolas se ajustam mais rapidamente do que os preços industriais. Neste caso, a desvalorização real da taxa de câmbio beneficiaria o setor agrícola relativo ao setor industrial, no curto prazo. Já os efeitos parciais imediatos de um aumento da taxa nominal de juros são a redução tanto do estoque nominal de moeda quanto do preço relativo agriculturaindústria, efeitos estes consistentes com o modelo teórico desenvolvido no capítulo 3.

$\mathrm{Na}$ Tabela 20 mostram-se as elasticidades de impulso do modelo VAR em nível com 3 defasagens. Estas elasticidades, também mostradas nas Figuras 11, 12 e 13, medem os efeitos contemporâneos completos de choques em TC, M1 e JN sobre RP. Note-se que os efeitos de choques em TC e JN sobre RP, medidos pelas elasticidades de impulso, são muito semelhantes ao modelo anterior no qual se considerou o estoque nominal de moeda numa posição mais exógena (ver Figuras 5 e 7). Em relação ao choque monetário (ver Figura 12), verifica-se que nos 5 primeiros meses as relações de troca são favoráveis ao setor agrícola. Essa relação se inverte a partir do sexto mês e volta a ser novamente favorável à agricultura a partir do décimo oitavo mês. 
Tabela 20 - Elasticidades de impulso sobre o preço relativo agricultura-indústria do modelo VAR em nível com 3 defasagens - taxa de juros exógena

\begin{tabular}{l|ccc}
\hline \multirow{2}{*}{ Meses após o choque } & \multicolumn{3}{c}{3 defasagens } \\
\cline { 2 - 4 } & TC & JN & M1 \\
\hline 01 & 0,3507 & $-0,0025$ & 0,0000 \\
02 & 0,5788 & $-0,0206$ & 0,0334 \\
03 & 0,3691 & $-0,0527$ & 0,0503 \\
06 & 0,2918 & $-0,0703$ & $-0,0130$ \\
12 & 0,1335 & $-0,0329$ & $-0,0185$ \\
18 & 0,0250 & $-0,0125$ & 0,0011 \\
24 & $-0,0160$ & $-0,0027$ & 0,0140 \\
\hline
\end{tabular}

Fonte: Dados da pesquisa.

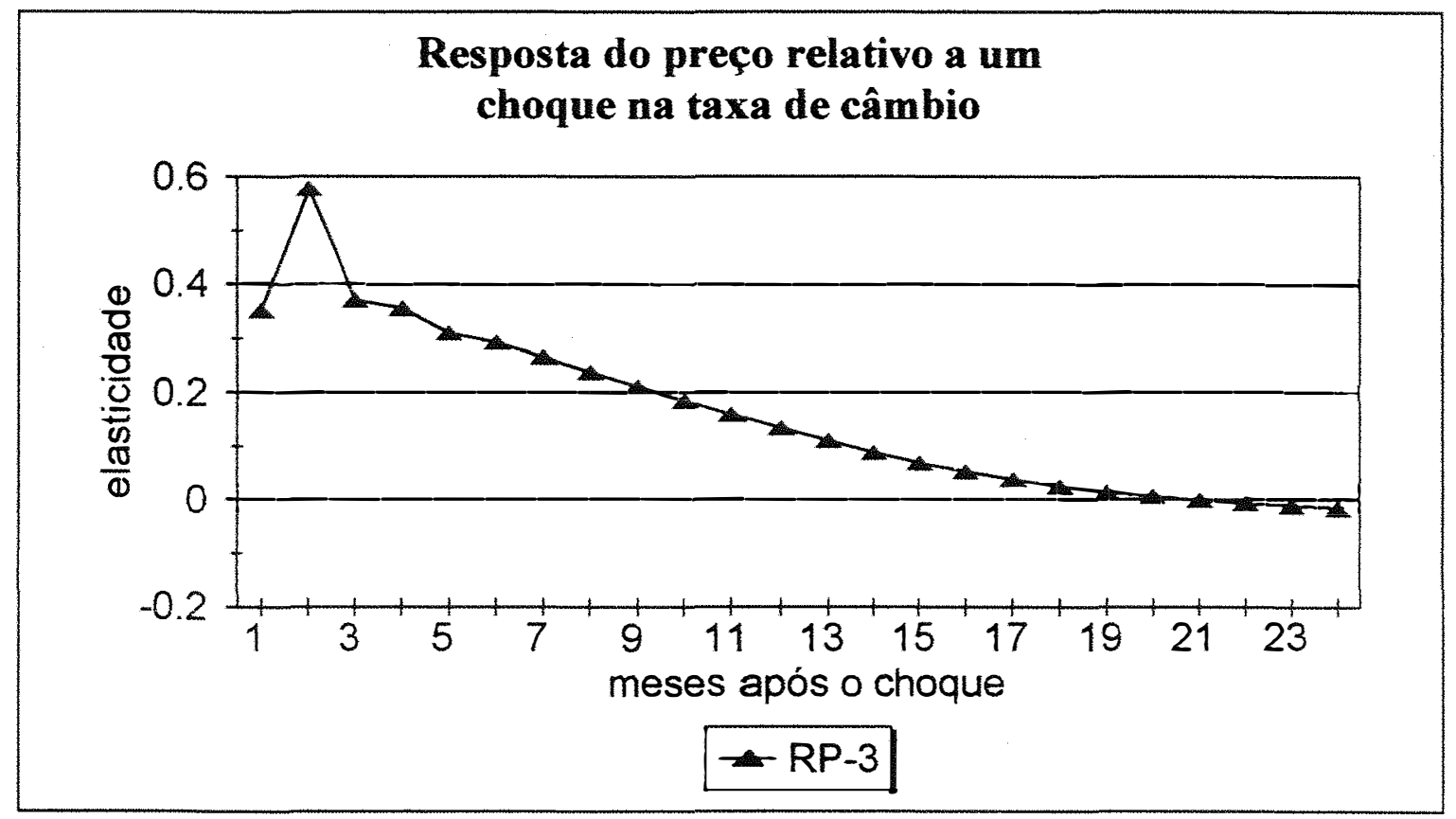

Figura 11 - Elasticidades de impulso da taxa de câmbio real sobre o preço relativo agricultura-indústria do modelo VAR em nível com 3 defasagens - taxa de juros exógena.

Fonte: Dados da pesquisa. 


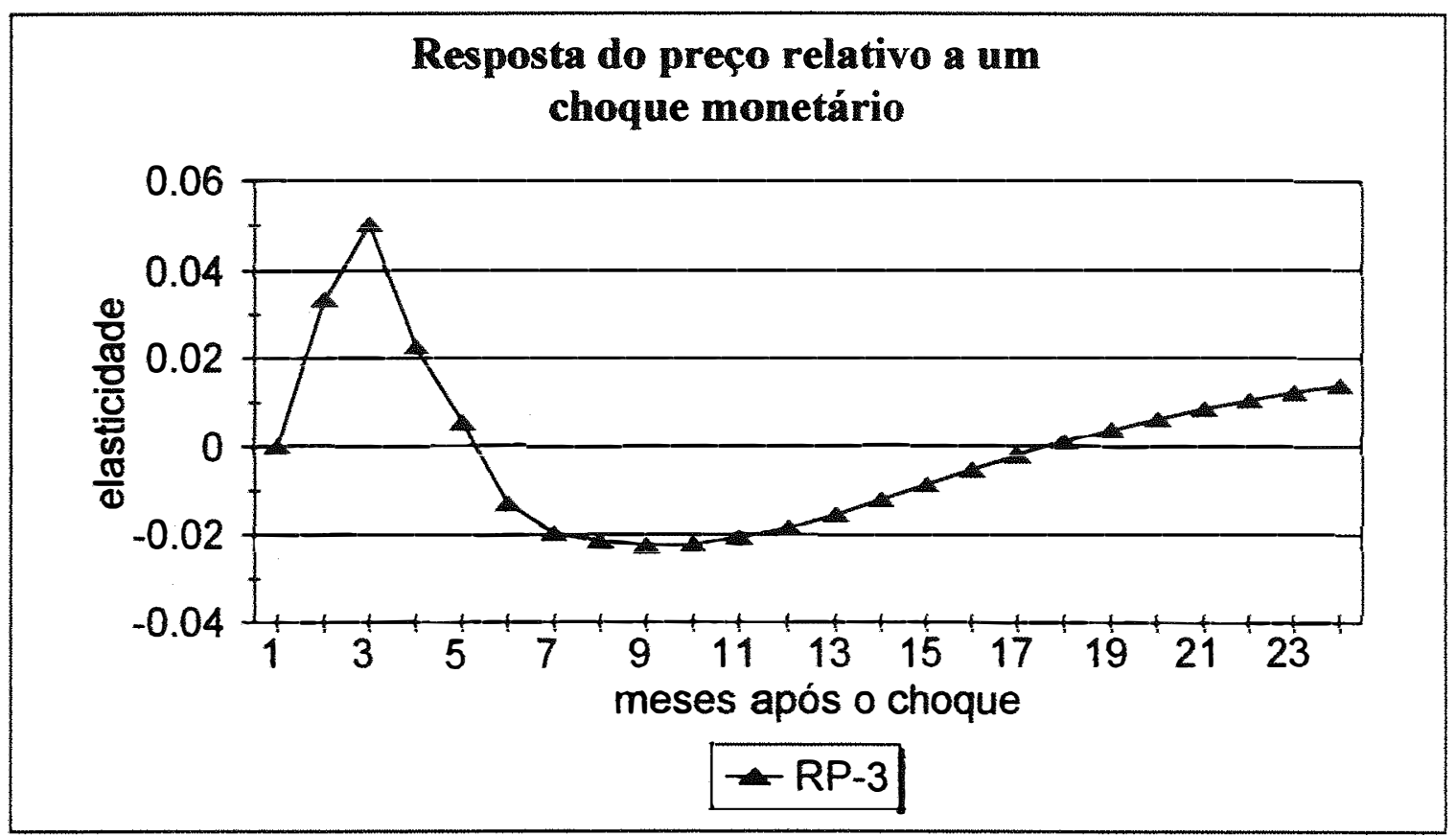

Figura 12 - Elasticidades de impulso da oferta monetária sobre o preço relativo agricultura-indústria do modelo VAR em nível com 3 defasagens - taxa de juros exógena.

Fonte: Dados da pesquisa.

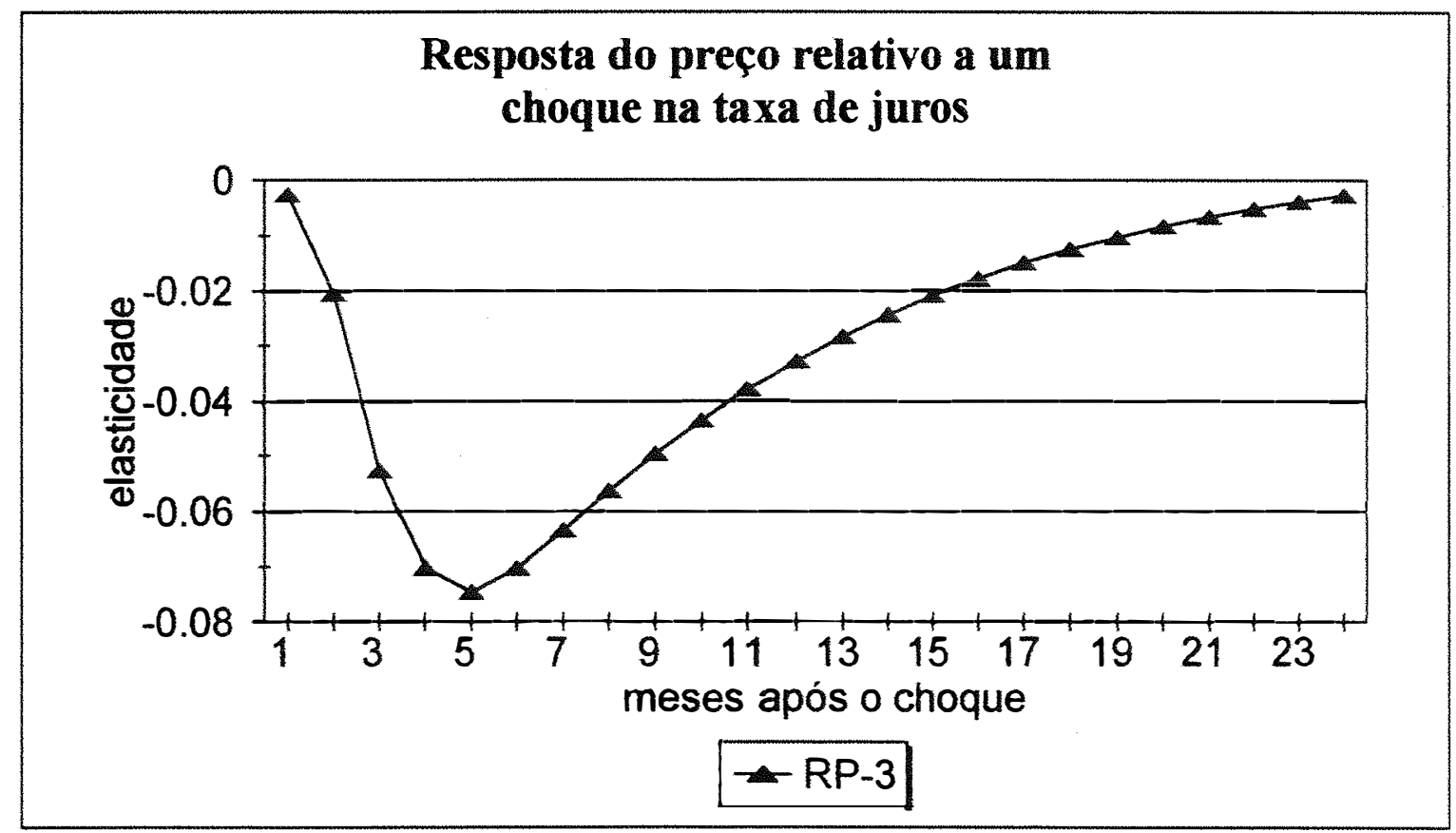

Figura 13 - Elasticidades de impulso da taxa nominal de juros sobre o preço relativo agricultura-indústria do modelo VAR em nivel com 3 defasagens - taxa de juros exógena.

Fonte: Dados da pesquisa. 
$\mathrm{Na}$ Tabela 21 apresenta-se a decomposição da variância dos erros de previsão do preço relativo agricultura-indústria do modelo VAR em nível com 3 defasagens, em percentagem. Esses resultados são muito parecidos com os encontrados para o modelo VAR em nível com 3 defasagens no qual se considera a variável M1 numa posição mais exógena (ver Tabela 11). De modo geral, RP, como no caso anterior, mostra-se exógena. Mais de $66 \%$ da variância do erro de previsão do preço relativo agricultura-indústria no primeiro ano é explicada por choques nele mesmo.

Tabela 21 - Decomposição da variância de previsão do preço relativo agriculturaindústria do modelo VAR em nível com 3 defasagens, em percentagem taxa de juros exógena

\begin{tabular}{l|cccc}
\hline \multirow{2}{*}{ Meses } & \multicolumn{4}{|c}{ 3 defasagens } \\
\cline { 2 - 5 } & TC & JN & M1 & RP \\
\hline 01 & 5,94 & 0,03 & 0,00 & 94,03 \\
02 & 10,72 & 1,04 & 0,16 & 88,08 \\
03 & 9,28 & 5,17 & 0,35 & 85,20 \\
06 & 8,18 & 17,45 & 0,24 & 74,13 \\
12 & 8,40 & 24,73 & 0,31 & 66,56 \\
18 & 8,41 & 26,01 & 0,33 & 65,25 \\
24 & 8,40 & 26,14 & 0,35 & 65,11 \\
\hline
\end{tabular}

Fonte: Dados da pesquisa.

Convém observar que o teste JOHANSEN-JUSELIUS para co-integração feito anteriormente (ver Tabela 15) é válido para essa nova situação, em que se coloca a taxa nominal de juros numa posição mais exógena na matriz de interações contemporâneas. Deve-se tomar cuidado apenas se existir mais de uma relação de cointegração, pois, em razão da normalização dos vetores de parâmetros estimados da matriz $\beta$, o segundo vetor coluna é diferente se forem considerados diferentes ordenações das variáveis na matriz $\mathrm{A}_{0}$; as relações de co-integração, neste caso, são diferentes.

As relações de co-integração, quando se considera a taxa de juros numa posição mais exógena na matriz $\mathrm{A}_{0}$, são dadas pelas seguintes expressões: 


$$
\begin{aligned}
& \mathrm{z}_{16 \mathrm{j}}=\mathrm{TC}-0,114 \mathrm{JN}-0,055 \mathrm{M} 1-0,569 \mathrm{RP}-1,920 \\
& \mathrm{z}_{26 \mathrm{j}}=8,002 \mathrm{TC}+\mathrm{JN}-0,323 \mathrm{M} 1-3,072 \mathrm{RP}-26,052 \\
& \mathrm{z}_{36 \mathrm{j}}=-7,791 \mathrm{TC}-2,028 \mathrm{JN}+\mathrm{M} 1-11,054 \mathrm{RP}+94,355
\end{aligned}
$$

Estimou-se o MCE com 6 defasagens (variáveis nas primeiras diferenças) e como termo de correção utilizaram-se as expressões de (61) a (63) com 1 defasagem. Na Tabela 22 mostram-se os parâmetros estimados da matriz $A_{0}$.

Tabela 22 - Matriz de interações contemporâneas $\left(\mathrm{A}_{0}\right)$ do MCE com 6 defasagens (variáveis nas primeiras diferenças) - taxa de juros exógena*

\begin{tabular}{l|cccc}
\hline Equações & \multicolumn{4}{|c}{ Variáveis } \\
\cline { 2 - 5 } & DTC & DJN & DM1 & DRP \\
\hline DTC & 1 & & & \\
DJN & & 1 & & \\
& & & & \\
DM1 & 0,3726 & 0,1638 & 1 & 1 \\
& $(0,3568)$ & $(0,0352)$ & & \\
DRP & $-0,8081$ & $-0,0081$ & & \\
& $(0,1900)$ & $(0,0187)$ & & \\
\hline
\end{tabular}

Fonte: Dados da pesquisa.

Nota: Entre parênteses estão as estimativas do desvio-padrão de cada coeficiente.

Verifica-se que são muito semelhantes os desvios-padrões estimados de cada coeficiente nos dois modelos, ou seja, no modelo VAR em nível com 3 defasagens e MCE com 6 defasagens. Como no modelo em nível, foram estatisticamente significativos (ver Tabela 19) a $5 \%$ de probabilidade apenas o coeficiente de DJN (coluna 2), na equação de DM1 (linha 3), e o coeficiente de DTC (coluna 1), na equação de DRP (linha 4). Os sinais dos coeficientes, quando comparados ao modelo em nivel, são diferentes (opostos) apenas no que diz respeito aos efeitos de choques inesperados na taxa nominal de juros sobre o preço relativo agricultura-indústria. 
As elasticidades de impulso das outras variáveis do modelo sobre o preço relativo agricultura-indústria (DRP) são mostradas na Tabela 23. Esses resultados são semelhantes aos do MCE com 6 defasagens no qual se considerou a oferta nominal de moeda (DM1) numa posição mais exógena na matriz $\mathrm{A}_{0}$ (ver Figuras 8,9 e 10 e comparar com as Figuras 14, 15 e 16). Em geral, esses modelos apresentaram uma trajetória de resposta de DRP aos choques (em DTC, DM1 e DJN) oscilatória. Confirmando resultados de todos os modelos anteriores, os efeitos dos choques cambiais foram mais significativos sobre o preço relativo agricultura-indústria do que os efeitos de choques monetários ou na taxa nominal de juros sobre esse preço.

Tabela 23 - Elasticidades de impulso sobre o preço relativo agricultura-indústria do MCE com 6 defasagens (variáveis nas primeiras diferenças) - taxa de juros exógena

\begin{tabular}{l|ccc}
\hline \multirow{2}{*}{ Meses após o choque } & \multicolumn{3}{c}{6 defasagens } \\
\cline { 2 - 4 } & DTC & DJN & DM1 \\
\hline 01 & 0,8081 & 0,0081 & 0,0000 \\
02 & 0,1937 & 0,0222 & 0,0398 \\
03 & $-0,0648$ & 0,0013 & 0,0618 \\
06 & $-0,0982$ & 0,0028 & 0,0545 \\
12 & $-0,0091$ & $-0,0016$ & 0,0125 \\
18 & 0,0547 & $-0,0058$ & $-0,0067$ \\
24 & 0,0447 & $-0,0085$ & 0,0017 \\
\hline
\end{tabular}

Fonte: Dados da pesquisa. 


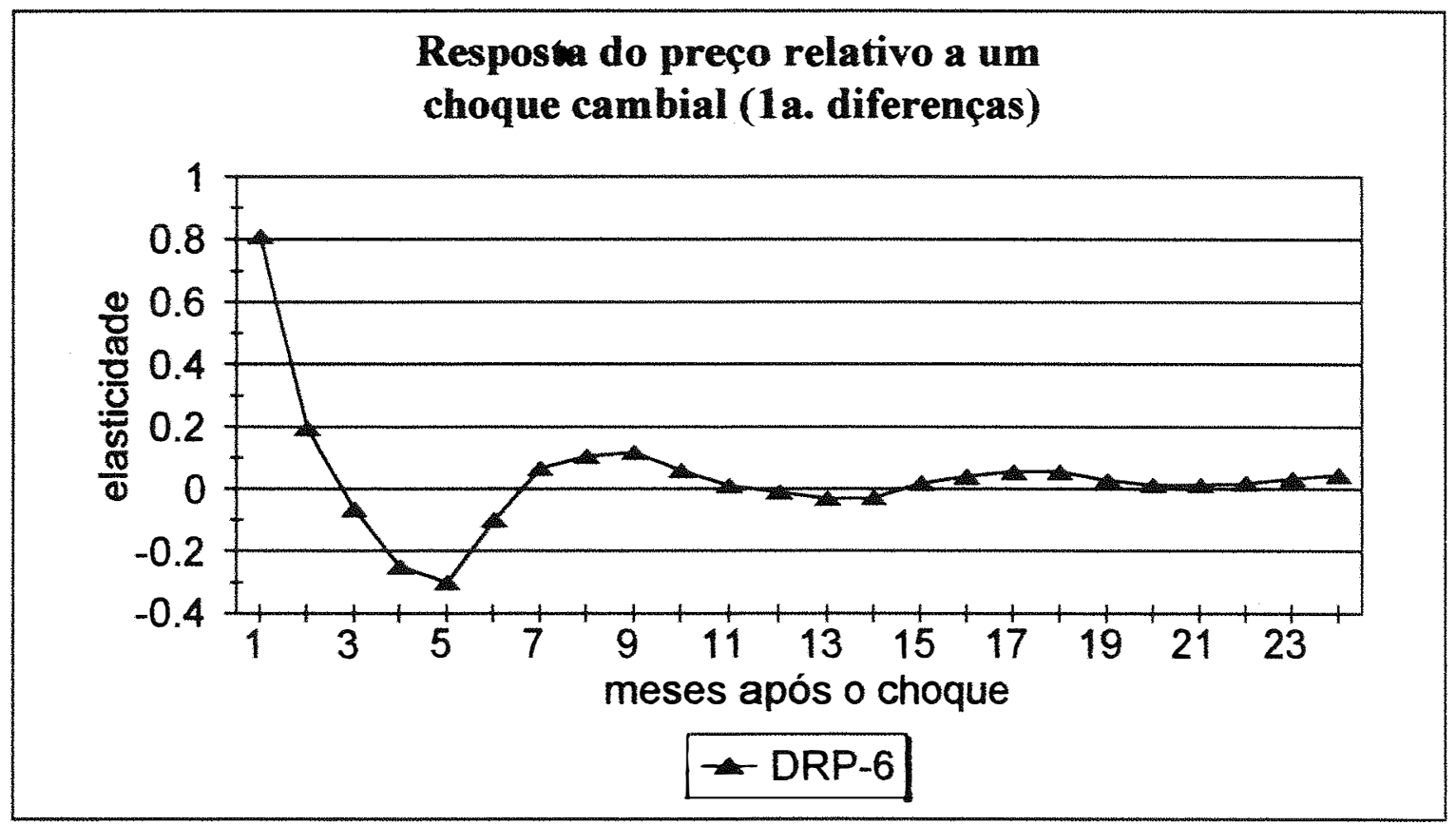

Figura 14 - Elasticidades de impulso da taxa de câmbio real sobre o preço relativo agricultura-indústria do MCE com 6 defasagens - taxa de juros exógena.

Fonte: Dados da pesquisa.

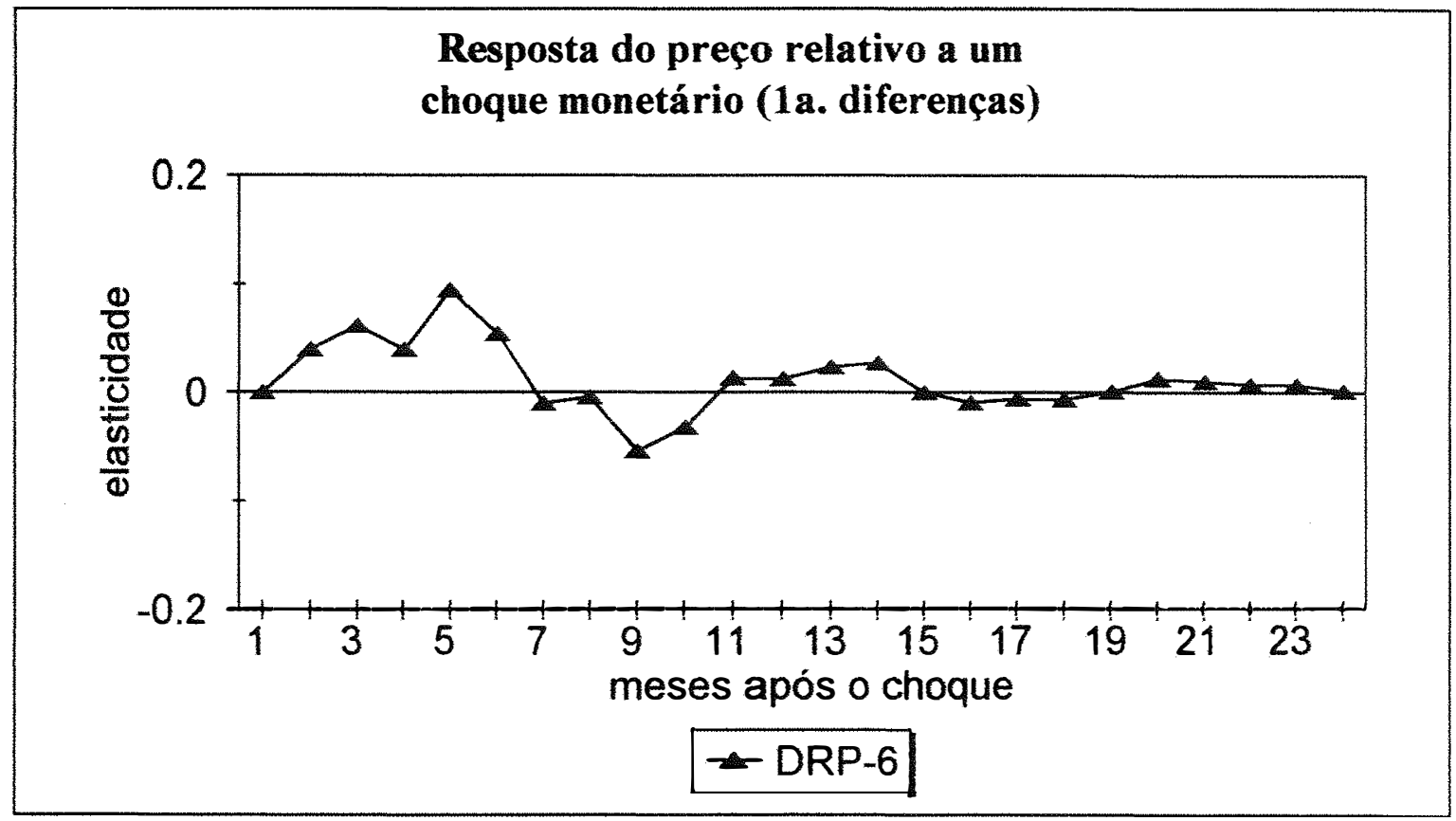

Figura 15 - Elasticidades de impulso da oferta monetária sobre o preço relativo agricultura-indústria do MCE com 6 defasagens - taxa de juros exógena.

Fonte: Dados da pesquisa. 


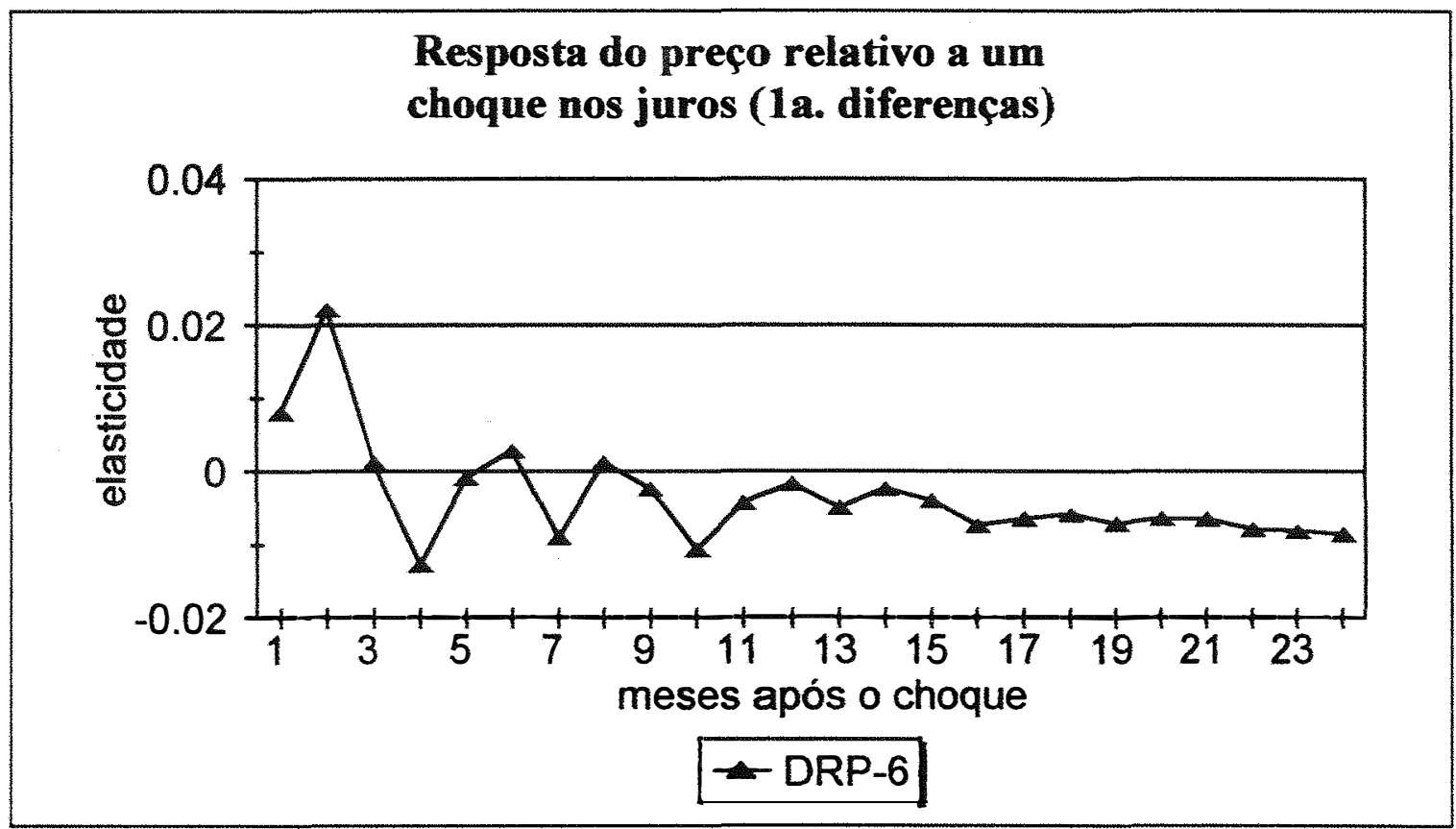

Figura 16 - Elasticidades de impulso da taxa nominal de juros sobre o preço relativo agricultura-indústria do MCE com 6 defasagens - taxa de juros exógena.

Fonte: Dados da pesquisa.

$\mathrm{Na}$ Tabela 24 apresenta-se a decomposição da variância dos erros de previsão do preço relativo agricultura-indústria do $\mathrm{MCE}$ com 6 defasagens, em percentagem. Esses resultados evidenciam, como em todos os modelos anteriores, um grau relativamente elevado de exogeneidade da variável DRP. Mais de $67 \%$ da variância de previsão dessa variável é explicada por choques inesperados nela mesma. O restante da explicação da variância de previsão é distribuído entre as demais variáveis do modelo. No caso da Tabela 22, a segunda variável mais importante na explicação (contribuindo com mais de $22 \%$ ) da variância de previsão de DRP é a variável DTC. 
Tabela 24 - Decomposição da variância do erro de previsão do preço relativo agricultura-indústria do MCE com 6 defasagens (variáveis nas primeiras diferenças), em percentagem - taxa de juros exógena

\begin{tabular}{l|cccc}
\hline \multirow{2}{*}{ Meses } & \multicolumn{4}{|c}{ 6 defasagens } \\
\cline { 2 - 5 } & DTC & DJN & DM1 & DRP \\
\hline 01 & 23,40 & 0,24 & 0,00 & 76,36 \\
02 & 23,72 & 1,98 & 0,41 & 73,89 \\
03 & 22,14 & 1,84 & 1,29 & 74,73 \\
06 & 23,96 & 2,10 & 3,97 & 69,97 \\
12 & 24,10 & 2,65 & 4,75 & 68,50 \\
18 & 24,03 & 3,09 & 4,97 & 67,91 \\
24 & 23,81 & 3,95 & 4,98 & 67,26 \\
\hline
\end{tabular}

Fonte: Dados da pesquisa.

\subsection{Comentários adicionais}

Dentre os principais resultados obtidos destaca-se o fato de que os modelos empíricos suportam a hipótese de que as políticas monetárias e cambiais afetam o termo doméstico de troca agricultura-indústria, no curto prazo. E o mais importante: os choques cambiais (desvalorizações da taxa de câmbio real) afetam este termo de troca mais intensamente do que os choques monetários (aumentos não esperados na oferta de moeda) ou choques (aumentos inesperados) na taxa nominal de juros. Esses resultados são consistentes com os dados estatísticos da evolução do índice de preço relativo agricultura-indústria analisado no capítulo 2 deste trabalho.

Uma possível explicação para os pequenos efeitos dos choques monetários sobre o preço relativo agricultura-indústria é a reduzida proporção dos meios de pagamento em relação aos outros ativos da economia. Com a aceleração da inflação, os agentes econômicos economizam encaixes reais, passando a demandar moeda apenas quando estritamente necessário (transações) e, com isso, a velocidade-renda da moeda se eleva. Assim, seriam necessários choques monetários maiores para produzirem os mesmos efeitos que seriam obtidos no caso de uma economia com um baixo nível de 
inflação e uma proporção maior dos meios de pagamento em relação ao produto interno bruto.

Identificar qual dos diversos modelos estimados é o melhor não é a questão mais importante neste trabalho. Os testes de raiz unitária e de defasagens no modelo VAR não foram suficientemente conclusivos. Caso se aceite, por exemplo, que as quatros séries de dados utilizadas são integradas de ordem um e que existe relação de co-integração entre elas, a melhor especificação é utilizar um modelo de correção de erro. Entretanto, os resultados obtidos nos diversos modelos são suficientemente robustos para se concluir que os choques monetários e cambiais foram importantes para explicar o comportamento do preço relativo agricultura-indústria no período analisado. 


\section{CONCLUSÕES}

Neste trabalho investigaram-se os efeitos de políticas monetárias e cambiais sobre o termo doméstico de troca agricultura-indústria, no curto prazo. Desenvolveu-se um modelo teórico, do tipo equilibrio de portfolio, no qual se considerou uma pequena economia aberta com taxa de câmbio fixa. Esta economia transaciona bens e ativos com o resto do mundo. As políticas monetárias (que podem ser restritivas ou expansionistas) consistem em operações de mercado aberto com títulos domésticos.

O modelo teórico permite a existência de indexação de preços na taxa de câmbio e/ou na formação dos preços industriais. Os resultados dos experimentos de estática comparativa com o modelo mostram que, de modo geral, os efeitos de políticas monetárias e cambiais sobre o preço relativo agricultura-indústria dependem da forma de indexação considerada.

Nas operações de mercado aberto expansionistas com títulos domésticos, o termo doméstico de troca agricultura-indústria melhora em favor da agricultura quando a taxa de câmbio não é indexada; no caso de haver apenas indexação cambial, o efeito desta política é ambíguo. Esta política deixa inalterado o preço relativo agriculturaindústria quando há indexação perfeita na economia.

Os efeitos de desvalorizações cambiais sobre o preço relativo agriculturaindústria são inequívocos quando há indexação apenas na formação dos preços industriais ou quando a indexação na economia é perfeita; nestes dois casos, os preços 
industriais crescem proporcionalmente mais do que os preços agrícolas. Nos outros casos, ou seja, ausência completa de indexação na economia doméstica ou quando há indexação apenas na taxa de câmbio, o efeito de uma desvalorização cambial sobre o preço relativo agricultura-indústria é ambíguo. Note-se que se está admitindo que a oferta monetária doméstica não é afetada pela desvalorização da taxa de câmbio.

Esse modelo forneceu o suporte teórico para a análise empírica. Nesta análise, que abrangeu o periodo de outubro de 1982 a dezembro de 1988, utilizaram-se modelos de auto-regressão vetorial (VAR). Realizaram-se testes para raiz unitária e cointegração nas séries mensais de dados consideradas e testes para definir o número de defasagens dos modelos empíricos. Com base nestes testes, optou-se por considerar modelos VAR com as variáveis em nível e modelos de correção de erro (MCE) com 3 e 6 defasagens.

Os resultados obtidos com esses modelos empíricos dão suporte à hipótese de que políticas monetárias e cambiais afetam o termo doméstico de troca agricultura-indústria, no curto prazo. Dentre os principais resultados obtidos, destaca-se o de que os choques não esperados na taxa de câmbio real afetam proporcionalmente mais o preço relativo agricultura-indústria do que choques da mesma magnitude na oferta monetária ou na taxa nominal de juros. Este resultado, no caso de choques na oferta de moeda ou na taxa de câmbio, é consistente com resultados encontrados anteriormente por outros autores que realizaram análises semelhantes para a economia brasileira. $^{1}$

Os coeficientes estimados das matrizes de interações contemporâneas, assim como seus respectivos desvios-padrões, nos diversos modelos considerados, são bastante semelhantes. Entretanto, os resultados desses modelos, relativos às elasticidades de impulso e à decomposição dos erros de previsão, apresentam algumas diferenças. Os ajustamentos do preço relativo agricultura-indústria aos choques monetários, cambiais ou na taxa nominal de juros foram mais rápidos nos modelos de correção de erro. Por

\footnotetext{
'Ver, por exemplo, BURNQUIST \& KYLE (1992) ou BARROS (1992).
} 
outro lado, esses mesmos choques foram bem mais acentuados nos modelos VAR em nível.

Nos modelos VAR em nível, os efeitos máximos de choques na oferta monetária ou na taxa nominal de juros sobre o preço relativo agricultura-indústria tendem a ocorrer entre o terceiro e o quinto mês e tornam-se bem menos intensos por volta do vigésimo mês. Os efeitos máximos desses choques na taxa de câmbio real ocorrem por volta do segundo mês, o que evidencia uma resposta mais rápida do preço relativo agricultura-indústria a esse choque quando comparados aos anteriores.

Nos modelos de correção de erro, os efeitos dos choques cambiais, na oferta de moeda ou na taxa nominal de juros sobre o preço relativo agricultura-indústria tendem a desaparecer por volta do quarto/quinto mês nos modelos com um menor número de defasagens. Note-se que, nesses modelos, as variáveis estão sendo consideradas nas primeiras diferenças. O efeito máximo de um choque de $10 \%$ na taxa de câmbio real (primeiras diferenças) sobre o preço relativo agricultura-indústria (primeiras diferenças) está entre 4 e $7 \%$, dependendo do número de defasagens consideradas no modelo. Um choque na oferta de moeda ou na taxa nominal de juros (ambas nas primeiras diferenças) da mesma magnitude provoca um aumento máximo de menos de $1 \%$ nesse preço.

A variância de previsão do preço relativo agricultura-indústria (em nível ou nas primeiras diferenças) é explicada em grande parte por choques nele mesmo. No modelo VAR em nivel, a participação desse preço na explicação de sua própria variância de previsão é superior a $54 \%$, nos seis primeiros meses. Após, então, aumenta a importância relativa das outras variáveis na explicação de sua variância de previsão. No caso dos modelos de correção de erro, mais de $69 \%$ da variância de previsão do preço relativo agricultura-indústria é explicada por choques nele mesmo.

É clara a evidência, a partir do exposto, de que desvalorizações cambiais e políticas monetárias expansionistas favorecem o setor agrícola relativamente ao setor industrial, no curto prazo. Pode-se inferir, a partir disso, que a atual política econômica 
brasileira, que conjuga abertura ao exterior com estabilização, não é benéfica para a agricultura, no curto prazo. Os principais fatores que contribuem para isso são as taxas de juros relativamente elevadas e a sobrevalorização cambial. 


\section{REFERÊNCIAS BIBLIOGRÁFICAS}

AGUIAR, D. R. D. Custo, risco e margem de comercialização de arroz e feijão no estado de São Paulo: análise dinâmcia e teste de modelos alternativos. Piracicaba, 1984. 185p. Tese (Doutorado) - Escola Superior de Agricultura Luiz de Queiroz, Universidade de São Paulo.

BACCHI, M. R. P. \& HOFFMANN, R. Previsão de preços de bovino e frango com modelos de series temporais. Revista de Econometria, 1995. (no prelo).

BANCO CENTRAL DO BRASIL (BACEN). Brasil - Programa Econômico, vols. 12, 16 e 20.

BARBOSA, F. de H. Ensaios sobre inflação e indexação. Rio de Janeiro: Editora da Fundação Getúlio Vargas, 1987. 168p.

BARROS, G. S. A. C. Efeitos de políticas macroeconômicas sobre a agricultura brasileira. Piracicaba: FEALQ, 1990. 175p. (Relatório de pesquisa).

BARROS, G. S. A. C. Impacts of monetary and real factors on the US dollar in identifiable VAR models. Revista Brasileira de Economia, Rio de Janeiro, v. 45, n. 4, p. 519-41, out./dez. 1991.

BARROS, G. S. A. C. Effects of international shocks and domestic macroeconomic policies upon Brazilian agriculture. Agricultural Economics, Amsterdam, n. 7, p. 317-329. 1992.

BERNANKE, B. S. Alternative Explanations of the money-income correlation. Carnegie-Rochester Conference Series on Public Policy. n. 25, p. 49-100. 1986.

BESSLER, D. A. Relative price and money: a vector autoregression on Brazilian data. American Journal of Agricultural Economics, n. 66, p. 25-30. 1984.

BLANCHARD, O. J. \& WATSON, M. Are business cycles all alike? National Bureau of Economic Research Working Paper n.1392. 1984.

BOX, G. E. \& JENKINS, G. M. Time series analysis: forecasting and control. San Francisco: Holden-Day, 1976.

BOYER, R. Commodity markets and bond markets in a small, fixed exchange rate economy. Can. J. Econ, n. 8, p. 1-23. 1975. 
BRANDÃO, A. S. P. Moeda e preços relativos: evidência empírica. Revista de Econometria, Rio de Janeiro, v. 5, n. 2, p. 33-80, nov. 1985.

BRANDÃO, A. S. P. \& ORDEN, D. Money and relative prices in Brazil. XII Latin American Meeting of the Econometric Society, ago. 1993.

BRESSER PEREIRA, L C. Os dois congelamentos de preços no Brasil. Revista de Economia Política, v. 8, n. 4, p. 48-66. 1988.

BURNQUIST, H. L. Identifying effects of the macroeconomy on brazilian agricultural prices. New York, 1992. Thesis (PhD.) - Department of Agricultural Economics, Cornell University.

BURNQUIST, H. L. \& KYLE, S. Efeitos de políticas macro-monetárias sobre preços agrícolas. In: Anais do XXX Congresso Brasileiro de Economia e Sociologia Rural. Rio de Janeiro, 03-06/ago., p. 88-105. 1992.

CAMPBELL, J. Y. \& PERRON, P. Pitfalls and opportunities: what macroeconomists should know about unit roots. In: NBER - Macroeconomics Annual. Cambridge: Mass. MIT Press, 1991. p.141-219.

CAVALCANTI, C. B. Transferência de recursos ao exterior e substituição de dívida externa por dívida interna. Rio de Janeiro: BNDES, 1988. 93p.

CHAMBERS, R. G. Agricultural and financial market interdependence in the short run. American Journal of Agricultural Economics, n. 66, p. 12-24. 1984.

COCHRANE, J. H. A critique of the application of unit root tests. Journal of Economic Dynamics and Control. n. 15, p. 275-284. 1991

CONTADOR, C. R. \& SIlVA JR., L. C. A. Inflação, preços relativos e risco na agricultura: algumas notas. In: Anais do XXX Congresso Brasileiro de Economia e Sociologia Rural, Rio de Janeiro: SOBER, 1992. p. 27-34.

CRUZ, P. D. Dívida externa e política econômica. São Paulo: Editora Brasiliense, 1984.

DALL'ACQUA, F. Ajuste estructural y política agrícola en el Brasil: experiencias de los ochenta y perspectivas para los noventa. El Trimestre Económico, n. 59, p. 263296. 1992. 
DIAS, G. O papel da agricultura no processo de ajustamento: nota adicional. In: Anais do XXVII Congresso Brasileiro de Economia e Sociologia Rural. Piracicaba, 1989. p.310-317.

DICKEY, D. A. \& FULLER, W. A. Distribution of the estimator for auto-regressive time series with a unit root. Journal of the American Statistical Association, n. 74, p. 427-31. 1979.

DICKEY, D. A. \& FULLER, W. A. Likelihood ratio statistics for auto-regressive time series with a unit root. Econometrica, n. 49, p. 1057-72. 1981.

DOAN, T. A. RATS: user's manual - version 4. Evanston: Estima, 1992.

DOLADO, J. J., JENKINSON, T. \& SOSVILLA-RIVERO, S. Cointegration and unit roots. Journal of economic surveys. v. 4, n. 3, p. 249-273. 1990.

ENGLE, R. F. \& GRANGER, C. W. J. Co-integration and erro corretion representation, estimation and testing. Econometrica, n. 55, p. 251-76. 1987.

ENGLE, R. F. \& YOO, B. S. Forecasting and testing in co-integrated systems. J. Econometrics, n. 35, p.143-59. 1987.

FACKLER, P. L. Vector autoregressive techniques for structural analysis. Revista de análisis econômico, n. 2, p. 119-134. 1988.

FRANKEL, J. A. Expectations and commodity price dynamics: the overshooting model. American Journal of Agricultural Economics, n. 68, p. 344-348. 1986.

FULLER, W. A. Introduction to statistical time series. New York: John Wiler, 1976.

FUNDAÇÃO INSTITUTO BRASILEIRO DE GEOGRAFIA E ESTATÍSTICA (IBGE). Contas Nacionais.

FUNDAÇÃo GETÚlIO VARGAS (FGV). Conjuntura Eletrônica (banco de dados).

HAMILTON, J. D. Time series analysis. Princeton: Princeton University Press, 1994. $768 \mathrm{p}$

HECK, A. Introduction to maple. New York: Springer-Verlag New York, Inc., 1993. $497 \mathrm{p}$.

HICKS, J. The crisis in keynesian economics. New York: Basic Books, 1974. 
JOHANSEN, S. Statistical analysis of cointegration vectors. Journal of Economic Dynamics and Control, n. 12, p. 231-254. 1988.

JOHANSEN, S. \& JUSELIUS, K. Maximum likelihood estimation and inference on cointegration: with aplications to the demand for money. Oxford Bulletin of Economics and Statistics, n. 52, p. 169-219. 1990.

KALECKI, M. Teoria da Dinâmica Econômica. São Paulo: Editora Abril, 1978.

KENNEDY, P. A guide do econometrics. 3a. ed. Oxford: Blackwell, 1992. 410p.

KOURI, P. J. K. \& PORTER, M. G. International capital flows and portfolio equilibrium, Journal of Political Economy, v.82, n.3, p. 367-443, may/june. 1974.

LAMY, J. A. Mercado aberto e política monetária: a experiência brasileira recente. Rio de Janeiro: EPGE/FGV, 1987. 91p. Tese (Doutorado).

LOPES, J. do C. \& ROSSETTI, J. P. Economia monetária. 6a. ed. São Paulo: Editora Atlas, 1993. 368p.

LOYOLA, G. J. L. Preços relativos em um processo inflacionário. Rio de Janeiro: EPGE/FGV, 1991. 107p. Tese (Doutorado).

MANOEL, A. \& MENDONÇA DE BARROS, J. R. Agricultura brasileira: transformações e perspectivas na década de 80. In: XV Encontro Nacional de Economia. Salvador, dez., p.103-128. 1987.

MARINHO, H. Política monetária no Brasil: da teoria à prática. 3a. ed. Rio de Janeiro: Editora Campus, 1988. 145p.

MARTONE, C. L., LUQUE, C. A. \& LOPES, L. M. Mercado financeiro e ajustamento macroeconômico brasileiro: 1978-1985. São Paulo: IPE/USP, 1986. $84 \mathrm{p}$.

MODIANO, E. M. Salários, preços e câmbio: os multiplicadores dos choques numa economia indexada. Pesquisa e planejamento econômico, Rio de Janeiro, n.15, p.1-32. 1985.

MONTEZANO, R. M. da S. Controle monetário em economia aberta: o caso brasileiro no período 1974-1982. Rio de Janeiro: EPGE/FGV, 1989. 98p. Tese (Doutorado). 
MOURA DA SILVA, A. \& KADOTA, D. Inflação e preços relativos: o caso brasileiro, 1970/79. Estudos econômicos, São Paulo, n. 12, p. 5-30, abr. 1982.

ORDEN, D. \& FACKLER, P. Identifying monetary impacts on agricultural prices in VAR models, American Journal of Agricultural Economics, v. 71, 1989.

PASTORE, A. C. Inflação e expectativas como a política monetária numa regra de taxa de juros. Revista Brasileira de Economia, Rio de Janeiro, v.4, n. 44, p. 499-528, out./dez., 1990.

PHILLIPS, P. C. B. Time series regression with a unit root. Econometrica, n. 55, p. 277-301. 1987.

PHILLIPS, P. C. B. \& PERRON, P. Testing for unit root in time series regression. Biometrika, n. 75, p. 335-46. 1988.

REZENDE, G. C. Preços agrícolas e industriais na inflação brasileira recente (1986-91). In: Anais do XXX Congresso Brasileiro de Economia e Sociologia Rural, Rio de Janeiro, 1992. p. 46-60.

ROCHA, L. E. de V. Determinantes da taxa de câmbio real e seu efeito sobre os preços agrícolas. Viçosa, 1995. 198p. Dissertação (Mestrado) - Departamento de Economia Rural, Universidade Federal de Viçosa.

SAYAD, J. Inflação e agricultura. Pesquisa e planejamento econômico, Rio de Janerio, v. 9, n. 1, p. 1-32, abr. 1979.

SAYAD, J. Crédito rural e taxas reais de juros positivas. In: Anais da $\mathbf{X}$ Reunião Anual da ANPEC, Friburgo, RJ, 1985.

SCHUH, G. E. The exchange rate and U.S. agriculture. American Journal of Agricultural Economics, n. 56, p.1-13. 1974.

SENNA, J. J. Entraves ao controle monetário no Brasil. In: VELLOSO, J. P. dos R. (Org) Inflação, moeda e desindexação. São Paulo: Nobel, 1994. cap. 7, p. 135-147.

SIMONSEN, M. H. \& CYSNE, R. P. Macroeconomia. Rio de Janeiro: Editora ao Livro Técnico, 1989. 553p.

SIMS, C. Macroeconomics and reality. Econometrica, n. 48, p. 1-48. 1980.

SIMS , C. Are forecasting models usable for pollicy analysis? Quarterty reviewFederal Reserve Bank of Minneapolis. (winter), 1986. 
STAMOULIS, K. G. \& RAUSSER, G. C. Overshooting of agricultural prices. In: PAARLBERG, P. L. \& CHAMBERS, R. eds. Macroeconomics, agriculture and exchange rates. Boulder: Westview press, 1988. p.163-188.

THOMPSON, R. L. U.S. macroeconomic policy and agriculture. In: PAARLBERG, P. L. \& CHAMBERS, R. eds. Macroeconomics, agriculture and exchange rates. Boulder: Westview Press, 1988. cap. 7.

TOBIN, J. A general equilibrium approach to monetary theory. Journal of Money, Credit, and Banking. n. 1, p.15-29. 1969.

TOBIN, J. An essay on principles of debt management. In: TOBIN, J. Essays in Economics, v. 1. Macroeconomics. Amsterdam: North Holland Publishing Company, 1971.

VIAL, S. A. H. Desequilíbrios orçamentários: uma avaliação do déficit público e suas implicações sobre a política monetária. São Paulo, 1989. 144p. Dissertação (Mestrado) - Faculdade de Economia e Administração, Universidade de São Paulo.

WILLIAMS, C. H. \& BEWLWY, R. A. Price arbitrage between queensland cattle auctions, Australian Journal of Agricultural Economics, Sydney, v. 37, n.1, p.3355, abr. 1993.

ZINI JR. , A. A. O Brasil num cruzamento: dívida externa e exaustão fiscal. Revista de Economia Política. v. 10, n. 1, p. 32-52. 1990.

ZINI JR. , A. A. Taxa de câmbio e política cambial no Brasil. São Paulo: EDUSP/BM\&F, 1993. 192p. 
APÊNDICE 1 


\section{A - Experimentos de estática comparativa com o modelo teórico}

No capítulo 3 , seção 3.3 , fez-se a análise de estática comparativa do modelo teórico considerando-se que não há indexação na economia doméstica, ou seja, os parâmetros de indexação ( $\gamma$, para a taxa de câmbio, e $\theta$, na formação do preço industrial) foram igualados a zero. Neste apêndice apresenta-se o restante da análise de estática comparativa que foi iniciada naquela seção. Consideram-se, agora, as outras possiveis formas de indexação na economia doméstica.

Convém lembrar que o modelo na sua forma básica contém três condições de equilíbrio e uma equação de formação do preço industrial. Estas condições de equilíbrio são os mercados de moeda doméstica, títulos domésticos e bem agrícola. Consideram-se como variáveis endógenas o preço do bem agrícola, o preço do bem industrial, a taxa nominal de juros doméstica e a componente externa da oferta monetária doméstica. As variáveis exógenas são o volume de títulos domésticos e a taxa de câmbio. Note-se que o Banco Central pode alterar o crédito doméstico líquido e, por extensão, a oferta monetária doméstica.

Uma variação alternativa dessa formulação básica consiste em considerar a taxa de juros nominal doméstica como exógena. Esta é uma variação facilmente derivável da formulação inicial dada a grande flexibilidade dos modelos de equilíbrio de portfolio. Ademais, é reconhecida a dificuldade do Banco Central brasileiro em controlar a oferta de moeda. Em função disso, resta a esta instituição como opção de política monetária, o controle da taxa interna de juros.

$\mathrm{Na}$ próxima seção continua-se a análise de estática comparativa iniciada no capítulo 3, seção 3.3. Após, então, comenta-se sobre a análise de estática comparativa do modelo teórico considerando-se a taxa de juros nominal doméstica como exógena. Basicamente, apresentam-se os cálculos algébricos neste apêndice. 


\section{A.1 - Continuação da análise de estática comparativa iniciada no capítulo 3}

As outras formas de indexação que precisam ser consideradas são:

a) indexação apenas na formação do preço industrial: $\gamma=0, \theta=1$;

b) indexação apenas na taxa de câmbio: $\gamma=1, \theta=0$; e

c) indexação perfeita da economia: $\gamma=1, \theta=1$.

No caso de dificuldades para acompanhar os cálculos algébricos que serão apresentados a seguir, principalmente no que diz respeito aos significados dos parâmetros, o leitor deve voltar ao capítulo 3 deste estudo, pois é nesse capítulo que o modelo teórico foi desenvolvido e onde detalha-se muitos de seus aspectos.

\section{a) Indexação apenas na formação do preço industrial}

Para facilitar a apresentação, as matrizes e vetores recebem denominações específicas. Assim, a letra A (maiúscula) sempre se refere à matriz de parâmetros, a letra $\mathrm{M}$ associa-se ao vetor de moeda doméstica, a letra $\mathrm{B}$ ao vetor de títulos domésticos, a letra $C$ ao vetor de taxa de câmbio e a letra $E$ refere-se ao vetor de variáveis endógenas . São usados subscritos para caracterizar a forma de indexação considerada. No caso de ausência de indexação na economia, por exemplo, utilizou-se o subscrito 1 .

A matriz de parâmetros e os vetores associados às variáveis exógenas do modelo, no caso de indexação apenas na formação do preço industrial, são dadas por: 


$$
\begin{gathered}
A_{2}=\left[\begin{array}{cccc}
\left(m_{w}-1\right) E_{0} & -m_{r} & 0 & 0 \\
b_{w} E_{0} & b_{r} & 0 & 0 \\
0 & a_{r} & z+z^{*} / E_{0} & 0 \\
0 & 0 & -\pi_{1} / p_{A} & 1 / p_{I}
\end{array}\right], \quad E=\left[\begin{array}{c}
d B^{*} \\
d r \\
d p_{A} \\
d p_{1}
\end{array}\right] \\
M_{2}=\left[\begin{array}{c}
1-m_{w} \\
-b_{w} \\
0 \\
0
\end{array}\right], \quad B_{2}=\left[\begin{array}{c}
-m_{w} \\
1-b_{w} \\
0 \\
0
\end{array}\right] \text { e } \quad C_{2}=\left[\begin{array}{c}
\left(1-m_{w}\right) B^{*} \\
-b_{w} B^{*} \\
z^{*} p_{A} / E_{0}^{2} \\
\left(1-\pi_{1}\right) / E_{0}
\end{array}\right]
\end{gathered}
$$

As variações exógenas $d M, d B$ e $d E_{0}$ estão associadas, respectivamente, aos vetores $\mathrm{M}, \mathrm{B}$ e C. Nas operações de mercado aberto expansionistas, faz-se $d E_{0}=0$ e $d B=-d M$. O vetor resultante é multiplicado pelo inversa da matriz $A_{2}$ para se obter as variações associadas ao vetor de variáveis endógenas $\mathrm{E}$. No caso das desvalorizações cambiais, faz-se: $d M=0, d B=0$ e $d E_{0} \neq 0$ e multiplica-se a inversa da matriz $A_{2}$ pelo vetor $C_{2}$ para se obter os efeitos sobre as variáveis endógenas. ${ }^{1}$

Fazendo-se os cálculos para o caso de uma operação de mercado aberto expansionista e dividindo-se os resultados obtidos das variações nos preços agrícolas e industriais, obtém-se:

$$
\frac{d p_{A}}{d p_{1}}=\frac{1}{\pi_{1}}>1
$$

No caso de uma desvalorização cambial, a razão das variações dos preços agrícolas e industriais é dada por:

$$
\frac{d p_{A}}{d p_{I}}=\frac{z^{*}}{z^{*}+\left(1-\pi_{1}\right) z E_{0}}<1
$$

\footnotetext{
${ }^{1}$ Note-se que a oferta monetária doméstica está sendo mantida constante no caso das desvalorizações da taxa de câmbio. Como já comentado na Capitulo 3, se o cálculo é feito considerando-se que a oferta de moeda varie. o resultado obtido é uma expressão complexa de difícil definição do sinal.
} 


\section{b) Indexação apenas na taxa de câmbio}

A matriz de parâmetros e os vetores associados às variáveis exógenas, no caso de indexação apenas na taxa de câmbio, são dados por:

$A_{3}=\left[\begin{array}{cccc}\left(m_{w}-1\right) E_{0} p & -m_{r} & \left(m_{w}-1\right) \alpha_{1} E_{0} B^{*} & \left(m_{w}-1\right) \alpha_{2} E_{0} B^{*} \\ b_{w} E_{0} p & b_{r} & \alpha_{1} b_{w} E_{0} B^{*} & \alpha_{2} b_{w} E_{0} B^{*} \\ 0 & a_{r} & z+z^{*}\left(1-\alpha_{1} p_{A} / p\right) / E_{0} p & -z^{*} \alpha_{2} p_{A} / E_{0} p^{2} \\ 0 & 0 & -\left(1-\pi_{1}\right) \alpha_{1} / p & 1 / p_{1}-\left(1-\pi_{1}\right) \alpha_{2} / p\end{array}\right]$

$$
M_{3}=\left[\begin{array}{c}
1-m_{w} \\
-b_{w} \\
0 \\
0
\end{array}\right], \quad B_{3}=\left[\begin{array}{c}
-m_{w} \\
1-b_{w} \\
0 \\
0
\end{array}\right] \text { e } C_{3}=\left[\begin{array}{c}
\left(1-m_{w}\right) B^{*} p \\
-b_{w} B^{*} p \\
z^{*} p_{A} / E_{0}^{2} p \\
\left(1-\pi_{1}\right) / E_{0}
\end{array}\right]
$$

O resultado de uma operação de mercado aberto expansionista sobre a razão das variações dos preços agrícolas e industriais é igual a:

$$
\frac{d p_{A}}{d p_{I}}=\frac{-p+\left(1-\pi_{1}\right) \alpha_{2} p_{I}}{\left(1-\pi_{1}\right) \alpha_{1} p_{I}}
$$

O efeito de uma desvalorização cambial sobre a razão das variações dos preços agrícolas e industriais é igual a:

$$
\frac{d p_{A}}{d p_{I}}=\frac{p_{A} z^{*}}{\left(z E_{0} p+z^{*}\right)\left(1-\pi_{1}\right) p_{I}}
$$




\section{c) Indexação perfeita da economia}

A matriz de parâmetros e os vetores associados às variáveis exógenas, no caso de indexação perfeita da economia, são definidas da seguinte forma:

$$
A_{4}=\left[\begin{array}{cccc}
\left(m_{w}-1\right) E_{0} p & -m_{r} & \left(m_{w}-1\right) \alpha_{1} E_{0} B^{*} & \left(m_{w}-1\right) \alpha_{2} E_{0} B^{*} \\
b_{w} E_{0} p & b_{r} & \alpha_{1} b_{w} E_{0} B^{*} & \alpha_{2} b_{w} E_{0} B^{*} \\
0 & a_{r} & z+z^{*}\left(1-\alpha_{1} p_{A} / p\right) / E_{0} p & -z^{*} \alpha_{2} p_{A} / E_{0} p^{2} \\
0 & 0 & -\pi_{1} / p_{A}-\left(1-\pi_{1}\right) \alpha_{1} / p & 1 / p_{I}-\left(1-\pi_{1}\right) \alpha_{2} / p
\end{array}\right]
$$

$$
M_{4}=\left[\begin{array}{c}
1-m_{w} \\
-b_{w} \\
0 \\
0
\end{array}\right], \quad B_{4}=\left[\begin{array}{c}
-m_{w} \\
1-b_{w^{\prime}} \\
0 \\
0
\end{array}\right] \text { e } C_{4}=\left[\begin{array}{c}
\left(1-m_{w}\right) B^{*} p \\
-b_{w} B^{*} p \\
z^{*} p_{A} / E_{0}^{2} p \\
\left(1-\pi_{1}\right) / E_{0}
\end{array}\right]
$$

O efeito de uma política monetária expansionista sobre a razão das variações dos preços agrícolas e industriais e igual:

$$
\frac{d p_{A}}{d p_{1}}=1
$$

No caso de uma desvalorização cambial, o efeito sobre a razão das variações dos preços agrícolas e industriais é iguais a:

$$
\frac{d p_{A}}{d p_{I}}=\frac{z^{*}}{z^{*}+\left(1-\pi_{1}\right) z E_{0} p}<1
$$


Note-se que foram mostrados apenas os resultados dos cálculos algébricos de mais interesse deste estudo. Dentre os resultados mais importantes do modelo teórico (o cálculo completo foi mostrado apenas no caso de não indexação na economia doméstica, no capítulo 3), que independem da forma de indexação considerada, são que uma política monetária expansionista sempre leva a uma queda na taxa nominal de juros e que uma desvalorização da taxa de câmbio (mantendo fixa a oferta monetária doméstica) sempre leva a aumentos nos preços agricolas e industriais.

Não serão apresentados os resultados dos cálculos algébricos considerando a taxa nominal de juros exógena, pois os efeitos de variações nesta variável ou na taxa de câmbio sobre o preço relativo agricultura-indústria são os mesmos quando se a considera endógena no modelo teórico. Deve-se observar que um aumento na taxa nominal de juros equivale a uma política monetária restritiva (redução do estoque de moeda em circulação) ou vice-versa. Nessa derivação do modelo teórico, ou seja, com taxa nominal de juros exógena, tanto o volume de títulos domésticos quanto o estoque de moeda devem-se ajustar ao nível de mercado da taxa nominal de juros doméstica. 
APÊNDICE 2 
2.1. Critérios utililazados para a escolha do número de defasagens em séries univariadas - AKAIKE e SCHWARZ

Há diversas formulações equivalentes para o critério de informação de AKAIKE (AIC) e o crítério de SCHWARZ (SC). As formulações utilizadas no RATS, software utilizado neste estudo, são as seguintes:
AKAIKE:
$\operatorname{Tlog}(\mathrm{RSS})+2 \mathrm{~K}$
SCHWARZ: $\quad T \log (R S S)+K(\log T)$

em que

$$
\begin{aligned}
& \mathrm{K}=\text { número de regressores; } \mathrm{e} \\
& \mathrm{T}=\text { número de observações. }
\end{aligned}
$$

2.2. Critérios utilizados para a escolha do número de defasagens em séries multivariadas

2.2.1. Erro de predição final

$$
\operatorname{FPE}(p)=\left(\frac{T+n p+1}{T-n p-1}\right)^{n}\|\hat{\Sigma}\|
$$

2.2.2. Critério de informação de AKAIKE

$$
A I C(p)=\ln \|\hat{\Sigma}\|+\frac{2}{T}\left(n^{2} p+n\right)
$$

\subsubsection{Critério de HANNAN-QUINN}

$$
H Q(p)=\ln \|\hat{\Sigma}\|+\frac{2 \ln (\ln T)}{T}\left(n^{2} p+n\right)
$$




\subsubsection{Critério de SCHWARZ}

$$
S C(p)=\ln \|\hat{\Sigma}\|+\frac{\ln (T)}{T}\left(n^{2} p+n\right)
$$

em que

$$
\begin{aligned}
& \mathrm{p}=\text { número de defasagens; } \mathrm{e} \\
& \mathrm{n}=\text { número de variáveis do modelo. }
\end{aligned}
$$

Tabela A2 - Valores críticos das estatísticas $\tau, \tau_{\mu}$ e $\tau_{\tau}$ para raiz unitária, a $0,01 \mathrm{e}$ 0,05 de probabilidade, para 50 e 100 observações

\begin{tabular}{lll}
\hline Amostra & $1 \%$ & $5 \%$ \\
\hline Estatística $\tau$ & & \\
50 & $-2,62$ & $-1,95$ \\
100 & $-2,60$ & $-1,95$ \\
\hline Estatística $\tau_{\mu}$ & & \\
50 & $-3,58$ & $-2,93$ \\
100 & $-3,51$ & $-2,89$ \\
\hline Estatística $\tau_{\tau}$ & & \\
50 & $-4,15$ & $-3,50$ \\
100 & $-4,04$ & $-3,45$ \\
\hline
\end{tabular}

Fonte: FULLER (1976, p.373) (Tabela 8.5.2). 


\section{APÊNDICE 3}




\subsection{Séries de dados utilizadas na investigação empírica}

As seguintes séries de dados (nos logaritmos neperianos) foram utilizadas neste estudo: TC (taxa de câmbio real efetiva), M1 (oferta monetária), JN (taxa nominal de juros) e RP (preço relativo agricultura-indústria).

Tabela A3 - Séries de dados utilizados na investigação empírica, período outubro/82 a dezembro/88

\begin{tabular}{lllll}
\hline Mês/Ano & \multicolumn{1}{c}{ TC } & \multicolumn{1}{c}{ Ml } & \multicolumn{1}{c}{ JN } & \multicolumn{1}{c}{ RP } \\
\hline OUT/82 & 4.48709 & 0.33152 & 1.98924 & 4.22708 \\
NOV/82 & 4.5047 & 0.41127 & 2.09802 & 4.24299 \\
DEZ/82 & 4.56233 & 0.52398 & 2.1702 & 4.3166 \\
JAN/83 & 4.5499 & 0.53212 & 1.94591 & 4.33997 \\
FEV/83 & 4.67426 & 0.54696 & 1.90954 & 4.34886 \\
MAR/83 & 4.82743 & 0.52634 & 2.2439 & 4.43169 \\
ABR/83 & 4.8168 & 0.6062 & 2.39971 & 4.48425 \\
MAI/83 & 4.83891 & 0.63917 & 2.3979 & 4.48341 \\
JUN/83 & 4.79593 & 0.7533 & 2.43799 & 4.518 \\
JUL/83 & 4.76771 & 0.76927 & 2.36556 & 4.55501 \\
AGO/83 & 4.7863 & 0.80826 & 2.31649 & 4.60951 \\
SET/83 & 4.74962 & 0.89957 & 2.21375 & 4.67075 \\
OUT/83 & 4.78578 & 0.98758 & 2.26903 & 4.80023 \\
NOV/83 & 4.77419 & 1.05298 & 2.23965 & 4.73506 \\
DEZ/83 & 4.76266 & 1.20499 & 2.24177 & 4.68826 \\
JAN/84 & 4.7478 & 1.19953 & 2.33117 & 4.72523 \\
FEV/84 & 4.75664 & 1.21421 & 2.49651 & 4.70005 \\
MAR/84 & 4.82059 & 1.29617 & 2.42126 & 4.75249 \\
ABR/84 & 4.83911 & 1.43196 & 2.31451 & 4.84419 \\
MAI/84 & 4.80697 & 1.48367 & 2.27932 & 4.81493 \\
JUN/84 & 4.77689 & 1.54911 & 2.31944 & 4.74224 \\
JUL/84 & 4.73597 & 1.63938 & 2.48989 & 4.68976 \\
AGO/84 & 4.72989 & 1.71775 & 2.38047 & 4.66357 \\
SET/84 & 4.69274 & 1.84498 & 2.4757 & 4.65094 \\
OUT/84 & 4.66629 & 1.88916 & 2.55645 & 4.6768 \\
NOV/84 & 4.69511 & 2.04377 & 2.38509 & 4.69238 \\
DEZ/84 & 4.67138 & 2.30976 & 2.44322 & 4.67999 \\
JAN/85 & 4.63518 & 2.20487 & 2.63476 & 4.64266 \\
FEV/85 & 4.6415 & 2.32516 & 2.48157 & 4.64087 \\
MAR/85 & 4.60517 & 2.42216 & 2.57185 & 4.60517 \\
& & & & \\
& & & &
\end{tabular}


Tabela A3 (continuação)

\begin{tabular}{lllll}
\hline Mês/Ano & \multicolumn{1}{c}{ TC } & \multicolumn{1}{c}{ M1 } & \multicolumn{1}{c}{ JN } & \multicolumn{1}{c}{ RP } \\
\hline ABR/85 & 4.70408 & 2.52424 & 2.58551 & 4.60208 \\
MAI/85 & 4.76613 & 2.60484 & 2.51041 & 4.66607 \\
JUN/85 & 4.81059 & 2.77862 & 2.37304 & 4.73782 \\
JUL/85 & 4.8432 & 2.88187 & 2.30558 & 4.71548 \\
AGO/85 & 4.8154 & 3.01427 & 2.2439 & 4.79754 \\
SET/85 & 4.82079 & 3.163 & 2.34756 & 4.80262 \\
OUT/85 & 4.8433 & 3.2006 & 2.36744 & 4.73077 \\
NOV/85 & 4.82525 & 3.41823 & 2.34756 & 4.86962 \\
DEZ/85 & 4.82812 & 3.70668 & 2.6362 & 4.81542 \\
JAN/86 & 4.814 & 3.6147 & 2.81361 & 4.89899 \\
FEV/86 & 4.85201 & 3.7466 & 2.6769 & 4.91482 \\
MAR/86 & 4.93375 & 4.33509 & 0.16551 & 4.91282 \\
ABR/86 & 4.94611 & 4.51178 & 0.22314 & 4.9292 \\
MAI/86 & 4.96039 & 4.65446 & 0.19885 & 4.93698 \\
JUN/86 & 4.95249 & 4.79981 & 0.23902 & 4.94091 \\
JUL/86 & 4.96608 & 4.79748 & 0.66783 & 4.95093 \\
AGO/86 & 4.97507 & 4.86387 & 0.94391 & 4.96711 \\
SET/86 & 4.97711 & 4.91774 & 1.07841 & 4.99041 \\
OUT/86 & 4.98608 & 4.98794 & 0.67294 & 5.02441 \\
NOV/86 & 4.97054 & 5.0332 & 0.86289 & 5.0408 \\
DEZ/86 & 4.93384 & 5.10974 & 1.69928 & 5.02746 \\
JAN/87 & 4.97362 & 4.86348 & 2.3979 & 5.09808 \\
FEV/87 & 5.00726 & 4.92193 & 2.97604 & 5.00737 \\
MAR/87 & 5.0003 & 5.04047 & 2.48073 & 4.87478 \\
ABR/87 & 4.918 & 4.86815 & 2.72785 & 4.72859 \\
MAI/87 & 4.91294 & 4.8777 & 3.20397 & 4.67576 \\
JUN/87 & 4.91303 & 5.15206 & 2.89148 & 4.68202 \\
JUL/87 & 4.95926 & 5.24727 & 2.18717 & 4.76204 \\
AGO/87 & 4.99422 & 5.34023 & 2.09063 & 4.84762 \\
SET/87 & 5.00775 & 5.42278 & 2.07819 & 4.89622 \\
OUT/87 & 4.96805 & 5.53344 & 2.24601 & 4.87197 \\
NOV/87 & 4.96994 & 5.66303 & 2.55878 & 4.85324 \\
DEZ/87 & 4.95649 & 5.93144 & 2.66584 & 4.78253 \\
JAN/88 & 4.91121 & 5.82161 & 2.82019 & 4.71053 \\
FEV/88 & 4.87882 & 5.92204 & 2.90963 & 4.66443 \\
MAR/88 & 4.88713 & 6.0522 & 2.8088 & 4.63868 \\
ABR/88 & 4.876 & 6.17656 & 3.00815 & 4.71257 \\
MAI/88 & 4.87005 & 6.35255 & 2.92585 & 4.67172 \\
JUN/88 & 4.83843 & 6.50674 & 3.0042 & 4.7352 \\
JUL/88 & 4.80657 & 6.61229 & 3.2068 & 4.7592 \\
& & & &
\end{tabular}


Tabela A3 (continuação)

\begin{tabular}{lllll}
\hline Mês/Ano & TC & M1 & JN & \multicolumn{1}{c}{ RP } \\
\hline AGO/88 & 4.7946 & 6.71896 & 3.11972 & 4.73945 \\
SET/88 & 4.76917 & 6.96018 & 3.26767 & 4.75868 \\
OUT/88 & 4.79959 & 7.24096 & 3.39417 & 4.81259 \\
NOV/88 & 4.82267 & 7.42529 & 3.34674 & 4.7764 \\
DEZ/88 & 4.8138 & 7.83403 & 3.40917 & 4.79104 \\
\hline \multicolumn{5}{l}{ Fonte: Dados básicos da Fundação Getúlio Vargas (Conjuntura Eletrônica) }
\end{tabular}

